NATIONAL LABORATORY

MANAGED BY UT-BATTELLE

FOR THE DEPARTMENT OF ENERGY

\title{
Potential Radon-222 Emissions from the Thorium Nitrate Stockpile
}

\author{
J.W. Terry \\ W.H. Hermes
}




\section{DOCUMENT AVAILABILITY}

Reports produced after January 1, 1996, are generally available free via the U.S. Department of Energy (DOE) Information Bridge.

Web site http://www.osti.gov/bridge

Reports produced before January 1, 1996, may be purchased by members of the public from the following source.

National Technical Information Service

5285 Port Royal Road

Springfield, VA 22161

Telephone 703-605-6000 (1-800-553-6847)

TDD 703-487-4639

Fax 703-605-6900

E-mail info@ntis.fedworld.gov

Web site http://www.ntis.gov/support/ordernowabout.htm

Reports are available to DOE employees, DOE contractors, Energy Technology Data Exchange (ETDE) representatives, and International Nuclear Information System (INIS) representatives from the following source.

Office of Scientific and Technical Information

P.O. Box 62

Oak Ridge, TN 37831

Telephone 865-576-8401

Fax 865-576-5728

E-mail reports@adonis.osti.gov

Web site http://www.osti.gov/contact.html

This report was prepared as an account of work sponsored by an agency of the United States Government. Neither the United States Government nor any agency thereof, nor any of their employees, makes any warranty, express or implied, or assumes any legal liability or responsibility for the accuracy, completeness, or usefulness of any information, apparatus, product, or process disclosed, or represents that its use would not infringe privately owned rights. Reference herein to any specific commercial product, process, or service by trade name, trademark, manufacturer, or otherwise, does not necessarily constitute or imply its endorsement, recommendation, or favoring by the United States Government or any agency thereof. The views and opinions of authors expressed herein do not necessarily state or reflect those of the United States Government or any agency thereof. 
Environmental Sciences Division

Nuclear Science and Technology Division

\title{
POTENTIAL RADON-222 EMISSIONS FROM THE
} THORIUM NITRATE STOCKPILE

\author{
J.W. Terry \\ W.H. Hermes
}

Prepared for

U.S. Defense Logistics Agency

Defense National Stockpile Center

Arlington, Virginia

Date Published: August 2003

Prepared by

OAK RIDGE NATIONAL LABORATORY

Oak Ridge, Tennessee 37831-6285

managed by

UT-BATTELLE, LLC

for the

U.S. DEPARTMENT OF ENERGY

under contract DE-AC05-00OR22725 
Potential Radon-222 Emissions from the Thorium Nitrate Stockpile

\section{THIS PAGE INTENTIONALLY LEFT BLANK.}




\section{CONTENTS}

ACRONYMS AND ABBREVIATIONS $\ldots \ldots \ldots \ldots \ldots \ldots \ldots \ldots \ldots \ldots \ldots \ldots$

ABSTRACT $\ldots \ldots \ldots \ldots \ldots \ldots \ldots \ldots \ldots \ldots \ldots \ldots \ldots \ldots \ldots \ldots \ldots \ldots \ldots \ldots \ldots$ vii

1. INTRODUCTION $\ldots \ldots \ldots \ldots \ldots \ldots \ldots \ldots \ldots \ldots \ldots \ldots \ldots \ldots \ldots \ldots \ldots$

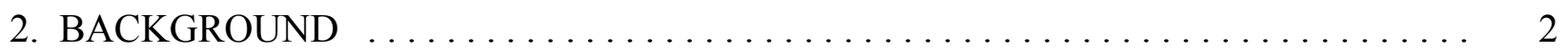

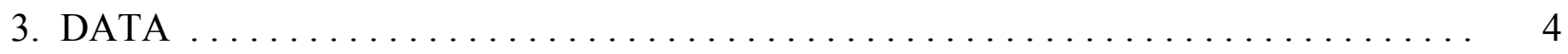

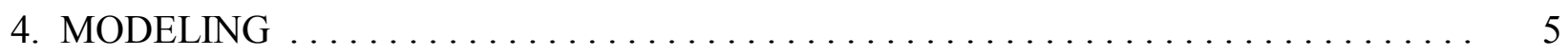

5. CONCLUSIONS $\ldots \ldots \ldots \ldots \ldots \ldots \ldots \ldots \ldots \ldots \ldots \ldots \ldots \ldots \ldots$

Appendix A-Applicable Constants and Conversion Factors . . . . . . . . . . . . A-1

Appendix B-Thorium Nitrate Constituents from Ore Data . . . . . . . . . . . . . B-1

Appendix $\mathrm{C}$-Thorium Sample Analysis Information $\ldots \ldots \ldots \ldots \ldots \ldots \ldots \ldots \ldots$

Appendix D-Decay Calculations Using Ore Data $\ldots \ldots \ldots \ldots \ldots \ldots \ldots \ldots \ldots \ldots$. $\ldots \ldots \ldots$

Appendix E-Decay Calculations Using Recent Data . . . . . . . . . . . . . . . E-1

Appendix F-Radon-222 Emission Calculations Using Preliminary Ore Data $\ldots \ldots \ldots$ F-1

Appendix G-Radon-222 Emission Calculations Using Maximum Values . . . . . . . . . . G-1 
Potential Radon-222 Emissions from the Thorium Nitrate Stockpile

\section{THIS PAGE INTENTIONALLY LEFT BLANK.}




\section{ACRONYMS AND ABBREVIATIONS}

$\begin{array}{ll}\text { CFR } & \text { Code of Federal Regulations } \\ \mathrm{d} & \text { day } \\ \mathrm{DNSC} & \text { Defense National Stockpile Center } \\ \mathrm{ft} & \text { feet } \\ \mathrm{g} & \text { gram } \\ \mathrm{h} & \text { hour } \\ \text { LLW } & \text { low-level waste } \\ \mathrm{m} & \text { meter } \\ \mathrm{MeV} & \text { mega-electron volt } \\ \mathrm{mR} & \text { milliroentgen } \\ \text { NTS } & \text { Nevada Test Site } \\ \text { ORNL } & \text { Oak Ridge National Laboratory } \\ \text { pCi } & \text { pico-Curies } \\ \text { sec or s } & \text { second } \\ \text { y } & \text { year }\end{array}$


Potential Radon-222 Emissions from the Thorium Nitrate Stockpile

\section{THIS PAGE INTENTIONALLY LEFT BLANK.}




\begin{abstract}
The Defense National Stockpile Center (DNSC), a field level activity of the Defense Logistics Agency, has stewardship of a stockpile of thorium nitrate that has been in storage for decades. The thorium nitrate stockpile was produced from 1959 to 1964 for the Atomic Energy Commission and previously has been under the control of several federal agencies. The stockpile consists of approximately 7 million pounds of thorium nitrate crystals (hydrate form) stored at two depot locations in the United States (75\% by weight at Curtis Bay, Maryland, and 25\% by weight at Hammond, Indiana). The material is stored in several configurations in over 21,000 drums. The U.S. Congress has declared the entire DNSC thorium nitrate stockpile to be in excess of the needs of the Department of Defense.

Part of DNSC's mission is to safely manage the continued storage, future sales, and/or disposition of the thorium nitrate stockpile. Historically, DNSC has sold surplus thorium nitrate to domestic and foreign companies, but there is no demand currently for this material. Analyses conducted by Oak Ridge National Laboratory (ORNL) in 2001 demonstrated that disposition of the thorium nitrate inventory as a containerized waste, without processing, is the least complex and lowest-cost option for disposition.

A characterization study was conducted in 2002 by ORNL, and it was determined that the thorium nitrate stockpile may be disposed of as low-level waste. The Nevada Test Site (NTS) was used as a case study for the disposal alternative, and special radiological analyses and waste acceptance requirements were documented. Among the special radiological considerations is the emission of ${ }^{220} \mathrm{Rn}$ and ${ }^{222} \mathrm{Rn}$ from buried material. NTS has a performance objective on the emissions of radon: $20 \mathrm{pCi} \mathrm{m}^{-2} \mathrm{sec}^{-1}$ at the surface of the disposal facility. The radon emissions from the buried thorium nitrate stockpile have been modeled. This paper presents background information and summarizes the results of modeling radon emissions and compares those results with the NTS performance objective.
\end{abstract}


Potential Radon-222 Emissions from the Thorium Nitrate Stockpile

\section{THIS PAGE INTENTIONALLY LEFT BLANK.}




\section{INTRODUCTION}

The Defense National Stockpile Center (DNSC), a field level activity of the Defense Logistics Agency, has stewardship of a stockpile of thorium nitrate that has been in storage for decades. The thorium nitrate stockpile was produced from 1959 to 1964 for the Atomic Energy Commission and previously has been under the control of several federal agencies. The stockpile consists of approximately 7 million pounds of thorium nitrate crystals (hydrate form) stored at two depot locations in the United States (75\% by weight at Curtis Bay, Maryland, and 25\% by weight at Hammond, Indiana). The material is stored in several configurations in over 21,000 drums. The gamma dose at the surface of an isolated drum is $20-30 \mathrm{mR} / \mathrm{h}$; however, the gamma dose within the storage facilities is $60-100 \mathrm{mR} / \mathrm{h}$. The stockpile is classified as source material (10 CFR 20.1003) and is regulated by the U.S. Nuclear Regulatory Commission. The U.S. Congress has declared the entire DNSC thorium nitrate stockpile to be in excess of the needs of the Department of Defense.

Part of DNSC's mission is to safely manage the continued storage, future sales, and/or disposition of the thorium nitrate stockpile. Historically, DNSC has sold surplus thorium nitrate to domestic and foreign companies, but there is no demand currently for this material. Analyses conducted by Oak Ridge National Laboratory (ORNL) in 2001 demonstrated that disposition of the thorium nitrate inventory as a containerized waste, without processing, is the least complex and lowest-cost option for disposition. The viability of this disposition pathway required a determination of which portion, if any, of the inventory exhibits hazardous characteristics (e.g., Resource Conservation and Recovery Act D001 ignitability characteristic-equivalent to Department of Transportation oxidizer and/or D004 toxicity characteristic).

A characterization study was conducted in 2002 by ORNL. One hundred drums were sampled, and the samples were analyzed for chemical and radiological constituents. Salt block monoliths comprise the predominant physical form in the stockpile. Special container inspection and dose management assessments were completed to meet on-site material handling, transportation, and disposal site requirements. The Nevada Test Site (NTS) was used as a case study for the disposal alternative, and special radiological analyses and waste acceptance requirements were documented.

Among the special radiological considerations is the emission of ${ }^{220} \mathrm{Rn}$ and ${ }^{222} \mathrm{Rn}$ from buried material. NTS has a performance objective on the emissions of radon: $20 \mathrm{pCi} \mathrm{m} \mathrm{sec}^{-1}$ at the surface of the disposal facility. The radon emissions from the buried thorium nitrate stockpile have been modeled. This report presents background information and summarizes the results of modeling radon emissions and compares those results with the NTS performance objective. 


\section{BACKGROUND}

Thorium-232 occurs naturally and has a half-life of $1.40 \times 10^{10}$ years. The ${ }^{232} \mathrm{Th}$ decay series (see Fig. 1) begins with ${ }^{232} \mathrm{Th}$ and, after a series of alpha and beta emissions, reaches ${ }^{208} \mathrm{~Pb}$, a stable end product. In many steps in the series, gamma rays and conversion electrons are emitted. Thorium-232 is not a fissile isotope; but it can be used as a precursor to generate fissionable ${ }^{233} \mathrm{U}$, which can sustain a chain reaction. Uranium-233 generates significantly more neutrons in the course of thermal fission than either ${ }^{235} \mathrm{U}$ or ${ }^{239} \mathrm{Pu}$, making it a desirable fuel to sustain criticality, while having excess neutrons to breed more ${ }^{233} \mathrm{U}$ from thorium.

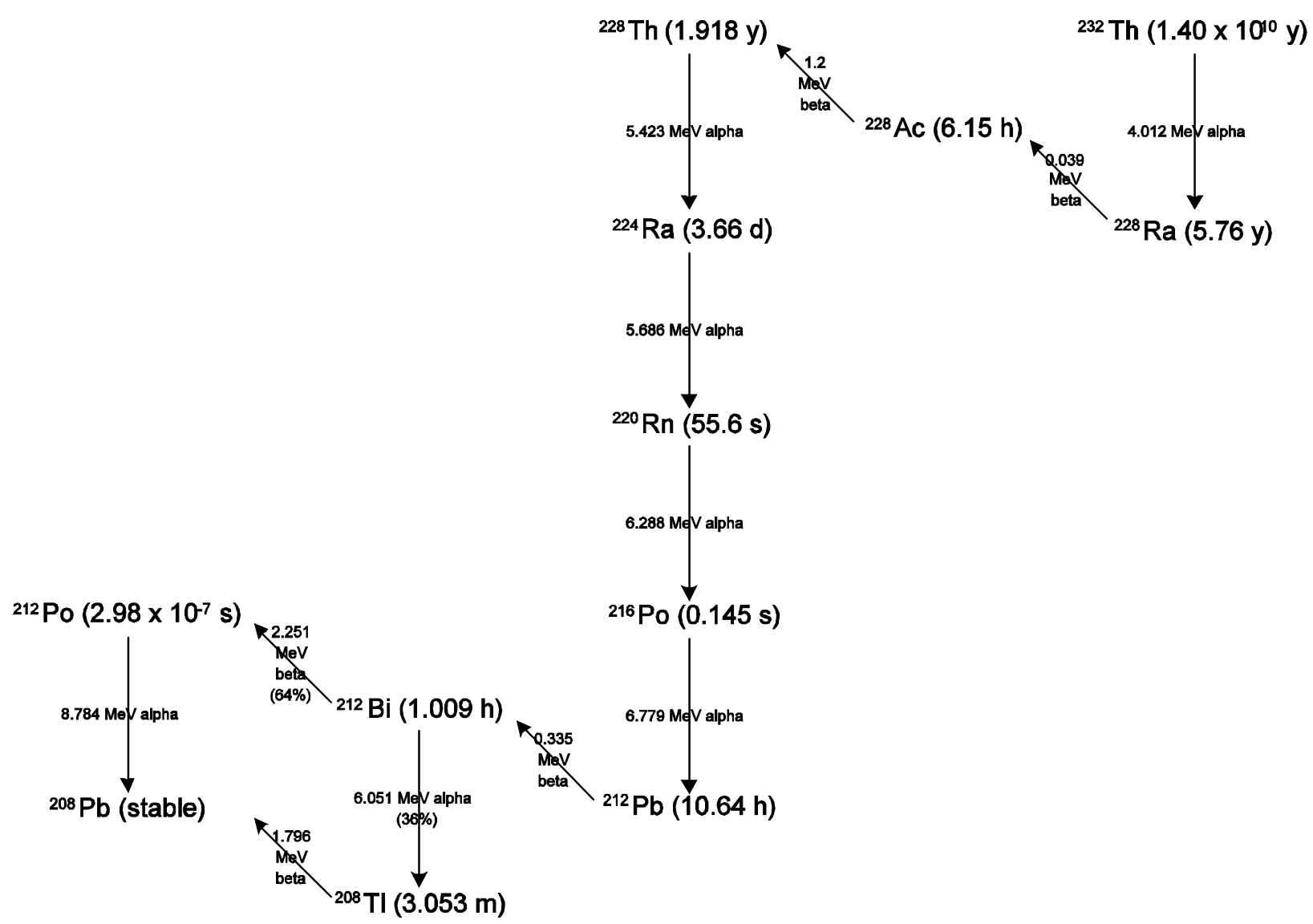

Fig. 1. Thorium-232 decay sequence. 
One of the progeny in the decay chain is ${ }^{220} \mathrm{Rn}$, a gas, which can escape and spread contamination. The decay chain continues beyond ${ }^{220} \mathrm{Rn}$; the highest radiation dose from shielded material comes from ${ }^{208} \mathrm{Tl}$, which emits a highly penetrating $2.6-\mathrm{MeV}$ gamma ray. Thus ${ }^{232} \mathrm{Th}$ progeny present both contamination and exposure risks to personnel and the environment.

Thorium-bearing ores typically contain substantial quantities of uranium. Uranium-238 is the most abundant $(99.2745 \%)$ of the naturally occurring isotopes of uranium. The half-life of ${ }^{238} \mathrm{U}, 4.47 \times 10^{9}$ years, is about one-third of the half-life of ${ }^{232} \mathrm{Th}$. The ${ }^{238} \mathrm{U}$ decay series (see Fig. 2) begins with ${ }^{238} \mathrm{U}$ and, after a series of alpha and beta emissions, reaches ${ }^{206} \mathrm{~Pb}$, a stable end product. As in the ${ }^{232} \mathrm{Th}$ decay sequence, many steps in the series result in the emission of gamma rays and conversion electrons. Unlike the ${ }^{232} \mathrm{Th}$ decay series, ${ }^{238} \mathrm{U}$ does not have a very high energy gamma-emitting progeny. Hence, the primary personnel and environmental radiological concern is contamination spread by ${ }^{222} \mathrm{Rn}$, a gas.

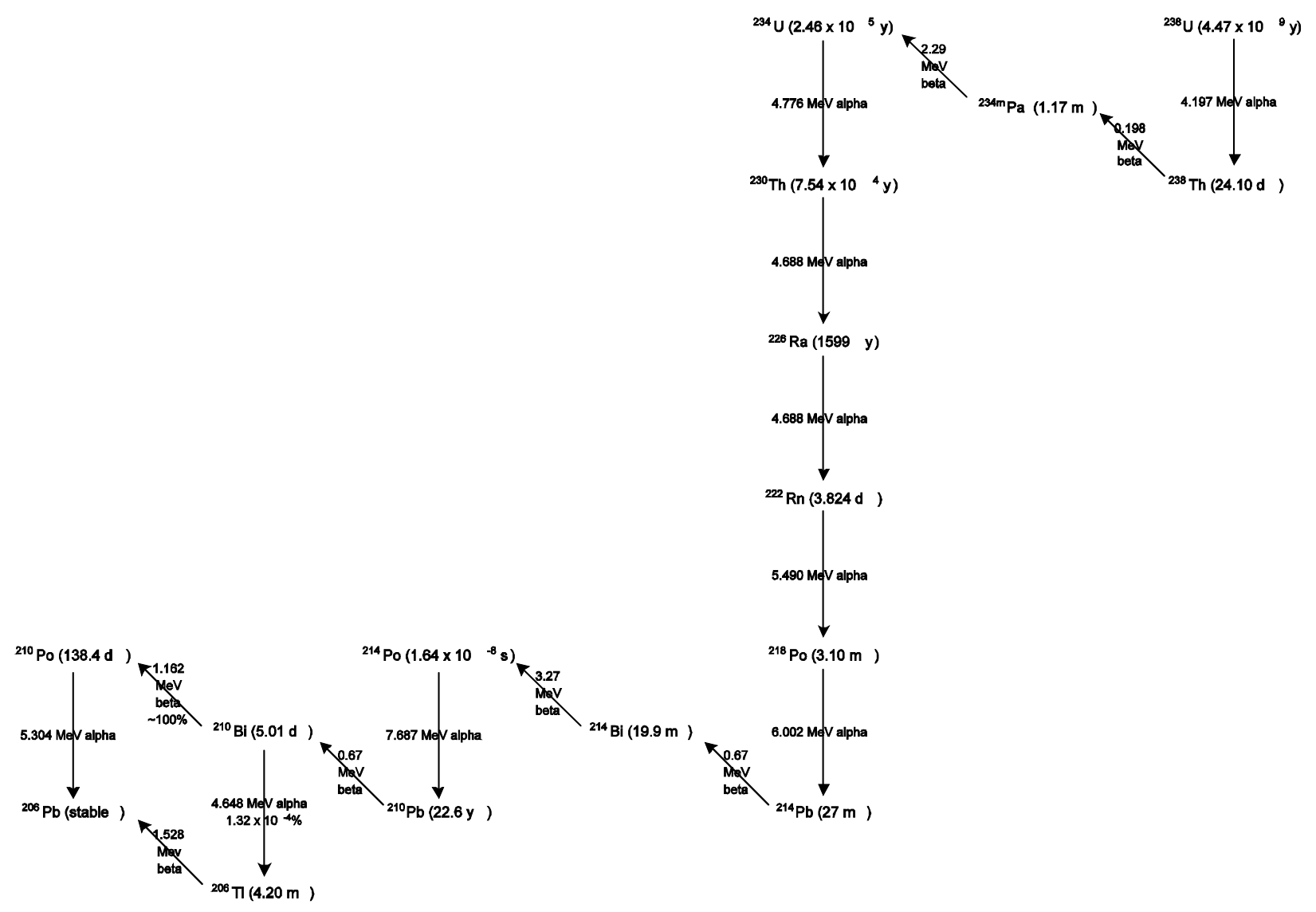

Fig. 2. Uranium-238 decay sequence. 
On the normal, macroscopic scale all isotopes of an element have almost identical physical and chemical characteristics. There are isotopic effects, but these effects are quite small for atoms of high atomic mass such as thorium and uranium. Thus, all isotopes of thorium would behave similarly during the physical and chemical processing required to extract thorium from the ore body and convert it to thorium nitrate. These physical and chemical processes would not distinguish between the ${ }^{232} \mathrm{Th}$ and ${ }^{228} \mathrm{Th}$ from the ${ }^{232} \mathrm{Th}$ decay sequence and the ${ }^{230} \mathrm{Th}$ from the ${ }^{238} \mathrm{U}$ decay sequence.

The thorium and uranium have been in the ore body for millions of years. Over this long time, the ${ }^{238} \mathrm{U}$ decay sequence has reached secular equilibrium; about 500,000 years is required for the ${ }^{238} U$ decay sequence to establish secular equilibrium. In secular equilibrium, there is one radioactive decay of each progeny in the decay sequence for every radioactive decay of the progenitor. Although ${ }^{232} \mathrm{Th}$ has a longer half-life than ${ }^{238} \mathrm{U}$, secular equilibrium for the ${ }^{232} \mathrm{Th}$ decay sequence is established in slightly over 100 years because none of its progeny have a halflife greater than 6 years.

\section{DATA}

The domestically produced thorium nitrate was chemically processed from monazite sands mined in South Africa; the thorium nitrate produced in France originated from ores mined in the Malagasy Republic; and the thorium nitrate produced in India originated from ores mined in India. The thorium nitrate produced domestically and in France is in the pentahydrate form, and the thorium nitrate produced in India is in the tetrahydrate form. The ${ }^{230}$ Th content of the three components of the thorium nitrate stockpile depends upon the amount of ${ }^{238} \mathrm{U}$ in the respective ore bodies. Preliminary data for the ${ }^{238} \mathrm{U}$ content of the thorium-containing ore bodies in South African, Malagasy Republic, and India were obtained from a published source (Benedict, Pigford, and Levi 1981). The published ratios of the average ${ }^{238} \mathrm{U}$ concentrations to the average thorium concentrations are as follows: 0.022 - ore from South Africa, 0.050 - ore from Malagasy Republic, and 0.042 — ore from India.

The ${ }^{230} \mathrm{Th}$ activity in the ores is assumed to have been equivalent to the ${ }^{238} \mathrm{U}$ activity because the uranium was present in the ores for geologic eras, providing more than sufficient time for secular equilibrium of the ${ }^{238} \mathrm{U}$ decay sequence to be established. To perform the calculations required to determine the ${ }^{222} \mathrm{Rn}$ emissions, an appropriate collection of constants and general data must be acquired; this information is given in Appendix A. All the thorium in the ore, including all the ${ }^{230} \mathrm{Th}$, is assumed to move into the thorium nitrate; this is equivalent to assuming a conversion efficiency of $100 \%$. This assumption would produce an overestimate (conservative estimate) of the amount of ${ }^{230} \mathrm{Th}$ in the stockpile if the ratios ${ }^{238} \mathrm{U}$ : Th are representative of the ores from which the thorium nitrate stockpile was produced. These assumptions and detailed calculations are presented in Appendix B. The resulting calculated ${ }^{230} \mathrm{Th}$ activities per gram of thorium nitrate are as follows: 
$2.685 \times 10^{3} \mathrm{pCi} / \mathrm{g}$ - ore mined in South Africa and processed in the United States, $6.187 \times 10^{3} \mathrm{pCi} / \mathrm{g}$ - ore mined in Malagasy Republic and processed in France, and $5.204 \times 10^{3} \mathrm{pCi} / \mathrm{g}$ - ore mined and processed in India.

In the spring and summer of 2002, a sampling and analysis program was conducted for the thorium nitrate stockpile. Representative samples were sent to Southwest Research Institute, a laboratory accredited by NTS, where they were analyzed for chemical and radiological constituents. Detailed assumptions and calculations are presented in Appendix C. The resulting average values of the measured ${ }^{230} \mathrm{Th}$ activities per gram of thorium nitrate are as follows:

$3.863 \times 10^{3} \mathrm{pCi} / \mathrm{g}$ - produced in the United States and stored at Hammond Depot, $4.290 \times 10^{3} \mathrm{pCi} / \mathrm{g}$ - produced in the United States and stored at Curtis Bay Depot, $39.59 \times 10^{3} \mathrm{pCi} / \mathrm{g}$ - produced in France and stored at Curtis Bay Depot, and $7.538 \times 10^{3} \mathrm{pCi} / \mathrm{g}$ - produced in India and stored at Curtis Bay Depot.

\section{MODELING}

NTS has developed a deterministic performance assessment model for disposal of lowlevel radioactive waste (LLW). The performance assessment included the computation of ${ }^{222} \mathrm{Rn}$ emissions from buried LLW. This deterministic performance assessment model is being replaced by a probabilistic model. In the replacement process, a new model for ${ }^{222} \mathrm{Rn}$ emissions is being developed and verified.

The newer ${ }^{222} \mathrm{Rn}$ emissions model is still under development and is not yet available for use. Hence, the older model was used for illustrative purposes. During discussions with NTS personnel, it was suggested that materials determined to have ${ }^{222} \mathrm{Rn}$ emissions substantially below the performance objective of $20 \mathrm{pCi} \mathrm{m}^{-2} \mathrm{sec}^{-1}$ at the surface of the ground using the older emissions model would likely remain below the performance objective using the newer model.

The NTS radon performance objective applies to any time between the present and 1000 years in the future. Before the NTS model could be applied, the time dependent levels of ${ }^{222} \mathrm{Rn}$ in the wastes were determined for both the preliminary ore data (see Appendix D) and the recent measurements (see Appendix E).

Although orders of magnitude more ${ }^{220} \mathrm{Rn}$ than ${ }^{222} \mathrm{Rn}$ will be generated in the thorium nitrate, the emissions of ${ }^{220} \mathrm{Rn}$ will not be computed. The NTS performance assessment model for deep burial provides a delay of about $1 / 3$ year between decay of radium into radon and emergence of radon from the ground. Only infinitesimal amounts of ${ }^{220} \mathrm{Rn}$ could emerge because this delay period is equivalent to roughly 200,000 half-lives for ${ }^{220} \mathrm{Rn}$.

Radon-222 is a decay product of both ${ }^{230} \mathrm{Th}$ and any ${ }^{238} \mathrm{U}$ contained in the thorium nitrate. Therefore, the activities of both progenitors were considered in the calculations. For the calculations performed using the preliminary ore data, it was assumed that ${ }^{238} \mathrm{U}$ occurred in the thorium nitrate at a concentration of $1 \mathrm{ppm}$ based upon mass spectroscopic data acquired from a single sample of thorium nitrate from DNSC; at this concentration no appreciable activity levels 
of ${ }^{222} \mathrm{Rn}$ would be generated at any time through 100,000 years in the future. Details of this calculation are presented in Appendix D. The highest measured ${ }^{238} \mathrm{U}$ activity levels, $\sim 8 \mathrm{pCi} / \mathrm{g}$, would produce vanishingly small activity levels of ${ }^{222} \mathrm{Rn}$ at any time through 100,000 years in the future. Details of this calculation are presented in Appendix E.

The ${ }^{230} \mathrm{Th}$ in the thorium nitrate from the original ore would create essentially all the ${ }^{222} \mathrm{Rn}$ at 1000 years in the future and beyond. The maximum generation of ${ }^{222} \mathrm{Rn}$ would occur at slightly less than 10,000 years in the future; details are presented in Appendices D and E. The calculated ${ }^{222} \mathrm{Rn}$ activity levels at 1000 years in the future are as follows:

\section{Preliminary ore data}

$0.940 \times 10^{3} \mathrm{pCi} / \mathrm{g}$ - ore mined in South Africa and processed in the United States, $2.164 \times 10^{3} \mathrm{pCi} / \mathrm{g}$ - ore mined in Malagasy Republic and processed in France, and $1.821 \times 10^{3} \mathrm{pCi} / \mathrm{g}$ - ore mined and processed in India.

\section{Recent measurements}

$1.564 \times 10^{3} \mathrm{pCi} / \mathrm{g}$ - produced in the United States and stored at Hammond Depot, $1.744 \times 10^{3} \mathrm{pCi} / \mathrm{g}$ - produced in the United States and stored at Curtis Bay Depot, $17.47 \times 10^{3} \mathrm{pCi} / \mathrm{g}$ - produced in France and stored at Curtis Bay Depot, and $2.670 \times 10^{3} \mathrm{pCi} / \mathrm{g}$ - produced in India and stored at Curtis Bay Depot.

Emissions of ${ }^{222} \mathrm{Rn}$ from the buried thorium nitrate depend upon the physical processes occurring during the movement of the ${ }^{222} \mathrm{Rn}$ to the ground surface. If the passage of the ${ }^{222} \mathrm{Rn}$ could be retarded for one or more half-lives $\left(t_{1 / 2}=3.824 \mathrm{~d}\right)$, much of it would decay into ${ }^{218}$ Po and successive ${ }^{222} \mathrm{Rn}$ progeny which would be trapped because they are not gases. The deeper the ${ }^{222} \mathrm{Rn}$ is buried, the more opportunity there is for its movement to be retarded or stopped.

At NTS, uranium and uranium-contaminated wastes are typically buried $26 \mathrm{ft}$ below the surface of the ground. Previously, a large quantity of thorium was buried $40 \mathrm{ft}$ below the surface of the ground to ensure that ${ }^{222} \mathrm{Rn}$ emissions met the performance objective of $20 \mathrm{pCi} \mathrm{m}^{-2} \mathrm{sec}^{-1}$ at all times through 1000 years in the future. The deterministic NTS model provides parameters that may be used to determine ${ }^{222} \mathrm{Rn}$ emissions from both depths. The ${ }^{222} \mathrm{Rn}$ emissions from the shallower depth were found to be unacceptably high for both the preliminary ore and the recently measured data. Details are given in Appendices F and G.

The ${ }^{222} \mathrm{Rn}$ emissions from the 40-ft depth were determined to be below the NTS limit through 1000 years in the future. Details of these calculations are presented in Appendices F and G. The calculated values are very low initially and grow to the following levels at 1000 years in the future: 
Preliminary ore data

$0.051 \mathrm{pCi} \mathrm{m}^{-2} \mathrm{sec}^{-1}$ - ore mined in South Africa and processed in the United States, $0.118 \mathrm{pCi} \mathrm{m}^{-2} \mathrm{sec}^{-1}$ — ore mined in Malagasy Republic and processed in France, $0.099 \mathrm{pCi} \mathrm{m}^{-2} \mathrm{sec}^{-1}$ — ore mined and processed in India, and $0.268 \mathrm{pCi} \mathrm{m}^{-2} \mathrm{sec}^{-1}$ - total emissions.

Recent measurements

$0.098 \mathrm{pCi} \mathrm{m}^{-2} \mathrm{sec}^{-1}$ — produced in the United States and stored at Hammond Depot, $0.109 \mathrm{pCi} \mathrm{m}^{-2} \mathrm{sec}^{-1}$ - produced in the United States and stored at Curtis Bay Depot, $1.090 \mathrm{pCi} \mathrm{m}^{-2} \mathrm{sec}^{-1}$ — produced in France and stored at Curtis Bay Depot, $0.167 \mathrm{pCi} \mathrm{m}^{-2} \mathrm{sec}^{-1}$ - produced in India and stored at Curtis Bay Depot, and $1.464 \mathrm{pCi} \mathrm{m}^{-2} \mathrm{sec}^{-1}$ - total emissions.

\section{CONCLUSIONS}

The modeled ${ }^{222} \mathrm{Rn}$ emissions from the thorium nitrate stockpile buried at NTS meet the NTS emissions limit if the material were buried $40 \mathrm{ft}$ below the surface of the ground. The published values for the average concentrations of uranium in ore bodies are not representative of the concentrations of uranium in the ore bodies from which the DNSC stockpile was produced.

\section{REFERENCE}

Benedict, M., T.H. Pigford, and H.W. Levi (1981). Nuclear Chemical Engineering, 2nd ed., McGraw-Hill, New York. 
Potential Radon-222 Emissions from the Thorium Nitrate Stockpile

\section{THIS PAGE INTENTIONALLY LEFT BLANK.}




\section{Appendix A}

\section{APPlicable CONSTANTS AND CONVERSION FACTORS}

Performing assessments of the potential radon emissions from burial of the thorium nitrate stockpile at Nevada Test Site requires a significant number of physical constants and conversion factors. The constants and conversion factors used in these assessments are presented in this appendix.

$$
\begin{aligned}
& \mathrm{d}=24.3600 \mathrm{sec} \quad \mathrm{d}=8.64 \times 10^{4} \mathrm{sec} \\
& y=365 d \quad y=3.1536 \times 10^{7} \mathrm{sec} \quad \min =60 \mathrm{sec} \\
& \lambda_{\mathrm{Rn} 222}=\text { decay constant of }{ }^{222} \mathrm{Rn} \quad \lambda_{\mathrm{Rn} 222}=\frac{\ln (2)}{3.8235} \mathrm{~d}^{-1} \quad \lambda_{\mathrm{Rn} 222}=66.169 \mathrm{y}^{-1} \\
& \lambda_{\text {Ra226 }}=\text { decay constant of }{ }^{226} \mathrm{Ra} \quad \lambda_{\text {Ra226 }}=\frac{\ln (2)}{1.600 \times 10^{3}} \mathrm{y}^{-1} \quad \lambda_{\text {Ra226 }}=4.332 \times 10^{-4} \mathrm{y}^{-1} \\
& \lambda_{\text {Th228 }}=\text { decay constant of }{ }^{228} \mathrm{Th} \quad \lambda_{\text {Th228 }}=\frac{\ln (2)}{1.913} \mathrm{y}^{-1} \quad \lambda_{\text {Th228 }}=0.362 \mathrm{y}^{-1} \\
& \lambda_{\text {Th230 }}=\text { decay constant of }{ }^{230} \mathrm{Th} \quad \lambda_{\text {Th230 }}=\frac{\ln (2)}{7.54 \times 10^{4}} \mathrm{y}^{-1} \quad \lambda_{\text {Th230 }}=9.193 \times 10^{-6} \mathrm{y}^{-1} \\
& \lambda_{\text {Th232 }}=\text { decay constant of }{ }^{232} \mathrm{Th} \quad \lambda_{\text {Th232 }}=\frac{\ln (2)}{1.40 \times 10^{10}} \mathrm{y}^{-1} \quad \lambda_{\text {Th232 }}=4.951 \times 10^{-11} \mathrm{y}^{-1} \\
& \lambda_{\text {Th234 }}=\text { decay constant of }{ }^{234} \mathrm{Th} \quad \lambda_{\text {Th234 }}=\frac{\ln (2)}{24.10} \mathrm{~d}^{-1} \quad \lambda_{\text {Th234 }}=10.498 \mathrm{y}^{-1} \\
& \lambda_{\mathrm{U} 234}=\text { decay constant of }{ }^{234} \mathrm{U} \quad \lambda_{\mathrm{U} 234}=\frac{\ln (2)}{2.46 \times 10^{5}} \mathrm{y}^{-1} \quad \lambda_{\mathrm{U} 234}=2.818 \times 10^{-6} \mathrm{y}^{-1} \\
& \lambda_{\text {U235 }}=\text { decay constant of }{ }^{235} \mathrm{U} \quad \lambda_{\mathrm{U} 235}=\frac{\ln (2)}{7.04 \times 10^{8}} \mathrm{y}^{-1} \quad \lambda_{\mathrm{U} 235}=9.846 \times 10^{-10} \mathrm{y}^{-1} \\
& \lambda_{\mathrm{U} 238}=\text { decay constant of }{ }^{238} \mathrm{U} \quad \lambda_{\mathrm{U} 238}=\frac{\ln (2)}{4.47 \times 10^{9}} \mathrm{y}^{-1} \quad \lambda_{\mathrm{U} 238}=1.551 \times 10^{-10} \mathrm{y}^{-1}
\end{aligned}
$$


$\mathrm{N}_{\mathrm{A}}=$ Avogadro's number

$\mathrm{m}_{\mathrm{Ra} 226}=$ atomic mass of ${ }^{226} \mathrm{Ra}$

$\mathrm{m}_{\mathrm{Rn} 222}=$ atomic mass of ${ }^{222} \mathrm{Rn}$

$\mathrm{m}_{\mathrm{Th} 228}=$ atomic mass of ${ }^{228} \mathrm{Th}$

$\mathrm{m}_{\mathrm{Th230}}=$ atomic mass of ${ }^{230} \mathrm{Th}$

$\mathrm{m}_{\mathrm{Th232}}=$ atomic mass of ${ }^{232} \mathrm{Th}$

$\mathrm{m}_{\text {Th234 }}=$ atomic mass of ${ }^{234} \mathrm{Th}$

$\mathrm{m}_{\mathrm{U} 235}=$ atomic mass of ${ }^{235} \mathrm{U}$

$\mathrm{m}_{\mathrm{U} 238}=$ atomic mass of ${ }^{238} \mathrm{U}$

$\mathrm{m}_{\mathrm{H}}=$ atomic mass of hydrogen

$\mathrm{m}_{\mathrm{O}}=$ atomic mass of oxygen

$\mathrm{m}_{\mathrm{N}}=$ atomic mass of nitrogen

$\mathrm{m}_{\mathrm{ThN}}=$ mass of thorium nitrate

$$
\mathrm{N}_{\mathrm{A}}=6.02214199 \times 10^{23} \quad \mathrm{gm}=1.000 \times 10^{-3} \mathrm{~kg}
$$

$\mathrm{m}_{\text {Ra226 }}=226 \mathrm{gm}$

$\mathrm{m}_{\mathrm{Rn222}}=222 \mathrm{gm}$

$\mathrm{m}_{\mathrm{Th} 228}=228 \mathrm{gm}$

$\mathrm{m}_{\mathrm{Th230}}=230 \mathrm{gm}$

$\mathrm{m}_{\mathrm{Th232}}=232.038051 \mathrm{gm}$

$\mathrm{m}_{\mathrm{Th228}}=234 \mathrm{gm}$

$\mathrm{m}_{\mathrm{U} 235}=235.043924 \mathrm{gm}$

$\mathrm{m}_{\mathrm{U} 238}=238.050785 \mathrm{gm}$

$\mathrm{m}_{\mathrm{H}}=1.0079 \mathrm{gm}$

$\mathrm{m}_{\mathrm{O}}=15.9994 \mathrm{gm}$

$\mathrm{m}_{\mathrm{N}}=14.0067 \mathrm{gm}$

$\mathrm{m}_{\mathrm{ThN}}=\mathrm{m}_{\mathrm{Th} 232}+4 \mathrm{~m}_{\mathrm{N}}+17 \mathrm{~m}_{\mathrm{O}}+10 \mathrm{~m}_{\mathrm{H}}$

$\mathrm{m}_{\mathrm{ThN}}=570.134 \mathrm{gm}$

$\mathrm{pCi}=1 \times 10^{-12} \mathrm{Ci}$
$\mathrm{Ci}=3.7 \times 10^{10} \mathrm{~Bq}$

$\mathrm{SpA}_{\mathrm{Th} 228}=$ specific activity of ${ }^{228} \mathrm{Th}$

$\mathrm{SpA}_{\mathrm{Th} 230}=$ specific activity of ${ }^{230} \mathrm{Th}$

$\mathrm{SpA}_{\mathrm{Th} 232}=$ specific activity of ${ }^{232} \mathrm{Th}$

$$
\mathrm{SpA}_{\mathrm{Th} 228}=\frac{\lambda_{\mathrm{Th} 228} \mathrm{~N}_{\mathrm{A}}}{\mathrm{m}_{\mathrm{Th} 228}} \quad \mathrm{SpA}_{\mathrm{Th} 228}=8.202 \times 10^{14} \frac{\mathrm{pCi}}{\mathrm{gm}}
$$$$
\mathrm{SpA}_{\mathrm{Th} 230}=\frac{\lambda_{\mathrm{Th} 230} \mathrm{~N}_{\mathrm{A}}}{\mathrm{m}_{\mathrm{Th} 230}} \quad \mathrm{SpA}_{\mathrm{Th} 230}=2.063 \times 10^{10} \frac{\mathrm{pCi}}{\mathrm{gm}}
$$

$\mathrm{SpA}_{\mathrm{Th} 232}=\frac{\lambda_{\mathrm{Th} 232} \mathrm{~N}_{\mathrm{A}}}{\mathrm{m}_{\mathrm{Th} 232}}$

$\mathrm{SpA}_{\mathrm{Th} 232}=1.101 \times 10^{5} \frac{\mathrm{pCi}}{\mathrm{gm}}$ 


$$
\begin{array}{lcc}
\mathrm{SpA}_{\mathrm{ThN}}=\begin{array}{l}
\text { specific activity of } \\
\text { thorium nitrate }
\end{array} & \mathrm{SpA}_{\mathrm{ThN}}=\frac{\lambda_{\mathrm{Th} 232} \mathrm{~N}_{\mathrm{A}}}{\mathrm{m}_{\mathrm{ThN}}} & \mathrm{SpA}_{\mathrm{ThN}}=4.482 \times 10^{4} \frac{\mathrm{pCi}}{\mathrm{gm}} \\
\mathrm{SpA}_{\mathrm{Th} 234}=\text { specific activity of }{ }^{234} \mathrm{Th} & \mathrm{SpA}_{\mathrm{Th} 234}=\frac{\lambda_{\mathrm{Th} 234} \mathrm{~N}_{\mathrm{A}}}{\mathrm{m}_{\mathrm{Th} 234}} & \mathrm{SpA}_{\mathrm{Th} 234}=2.315 \times 10^{16} \frac{\mathrm{pCi}}{\mathrm{gm}} \\
\mathrm{SpA}_{\mathrm{U} 235}=\text { specific activity of }{ }^{235} \mathrm{U} & \mathrm{SpA}_{\mathrm{U} 235}=\frac{\lambda_{\mathrm{U} 235} \mathrm{~N}_{\mathrm{A}}}{\mathrm{m}_{\mathrm{U} 235}} & \mathrm{SpA}_{\mathrm{U} 235}=2.162 \times 10^{6} \frac{\mathrm{pCi}}{\mathrm{gm}} \\
\mathrm{SpA}_{\mathrm{U} 238}=\text { specific activity of }{ }^{238} \mathrm{U} & \mathrm{SpA}_{\mathrm{U} 238}=\frac{\lambda_{\mathrm{U} 238} \mathrm{~N}_{\mathrm{A}}}{\mathrm{m}_{\mathrm{U} 238}} & \mathrm{SpA}_{\mathrm{U} 238}=3.362 \times 10^{5} \frac{\mathrm{pCi}}{\mathrm{gm}}
\end{array}
$$




\section{THIS PAGE INTENTIONALLY LEFT BLANK.}




\section{Appendix B}

\section{Thorium Nitrate Constituents From Ore Data}

\section{INTRODUCTION}

This appendix presents background information, assigns uranium and thorium activities in the thorium nitrate stockpile based upon published values for the ratios of uranium to thorium in the original ore body, and lists the calculated ${ }^{230} \mathrm{Th}$ activities per gram of thorium nitrate.

\section{BACKGROUND}

Western Australian mineral sands deposits contain up to $10 \%$ heavy minerals, of which $1-3 \%$ is monazite. This in turn typically contains $5-7 \%$ of radioactive thorium and $0.1-0.3 \%$ of uranium, which is barely radioactive (UIC 1998).

Thorium-234 and ${ }^{230} \mathrm{Th}$ are members of the ${ }^{238} \mathrm{U}$ decay chain. They are found in natural thorium when uranium is present in natural ores. Because the half-life of ${ }^{234} \mathrm{Th}$ is only 24.1 days, it soon decays in separated thorium, resulting in an inconsequential concentration. Thorium-230, however, has a 75.4-thousand-year half-life and is a significant constituent of thorium from ores containing uranium. The ${ }^{230} \mathrm{Th} /{ }^{232} \mathrm{Th}$ atom ratio is given by

$$
\frac{{ }^{230} \mathrm{Th}}{{ }^{232} \mathrm{Th}}=\mathrm{r}(0,2)=\frac{(0.9927)\left(7.54 \times 10^{4}\right)[\mathrm{r}(\mathrm{U}, \mathrm{Th})]}{4.47 \times 10^{9}}=1.68 \times 10^{-5} \mathrm{r}(\mathrm{U}, \mathrm{Th})
$$

where

$0.9927=$ the atom fraction of ${ }^{238} \mathrm{U}$ in natural uranium,

$\mathrm{r}(\mathrm{U}, \mathrm{Th})=$ the atomic ratio of U/Th in the ore, and

$4.47 \times 10^{9}=$ the half-life of ${ }^{238} \mathrm{U}$.

The ratio of the activity of ${ }^{230} \mathrm{Th}$ to ${ }^{232} \mathrm{Th}$ is given by

$$
\frac{{ }^{230} \mathrm{~A}}{{ }^{232} \mathrm{~A}}=\frac{{ }^{232} \mathrm{H} \times \mathrm{r}(0,2)}{{ }^{230} \mathrm{H}}=\frac{1.40 \times 10^{10}}{\left(7.54 \times 10^{4}\right)\left(1.68 \times 10^{-5}\right) \mathrm{r}(\mathrm{U}, \mathrm{Th})}=3.1 \mathrm{r}(\mathrm{U}, \mathrm{Th}),
$$

where $H$ is the half-life of the designated isotope. 
Thorium has been recovered as a by-product of uranium production from ores of the Blind River district in Ontario in which the U/Th ratio is 6 . In such thorium, the ${ }^{230} \mathrm{Th}$ activity is $3.1 \times 6$ or 18.6 times the activity of the ${ }^{232} \mathrm{Th}$.

There are about 12 minerals that contain thorium in the principal thorium-containing ore. Thorium production was a by-product of monazite processing during the period the stockpile was produced. Most of the world's thorium had come from beach sands where coproduction of rare earths, titanium, and zirconium defrayed much of the cost of extracting thorium. Because monazite is usually a minor constituent of the deposits of other minerals $(0.5-1.0 \mathrm{wt} \%)$, physical separations are first employed to concentrate the monazite up to $98 \%$ purity. The composition of the monazite concentrate, for $\mathrm{ThO}_{2}$ and $\mathrm{U}_{3} \mathrm{O}_{8}$, in weight percent, is as follows:

\begin{tabular}{cccccc} 
& India & Brazil & Florida beach sands & $\begin{array}{c}\text { South African } \\
\text { monazite rock }\end{array}$ & $\begin{array}{c}\text { Malagasay } \\
\text { Republic }\end{array}$ \\
\hline $\mathrm{ThO}_{2}$ & 8.88 & 6.5 & 3.1 & 5.9 & 8.75 \\
$\mathrm{U}_{3} \mathrm{O}_{8}$ & 0.35 & 0.17 & 0.47 & 0.12 & 0.41
\end{tabular}

From the data above,

\begin{tabular}{lccccc} 
& India & Brazil & Florida beach sands & $\begin{array}{c}\text { South African } \\
\text { monazite rock }\end{array}$ & $\begin{array}{c}\text { Malagasay } \\
\text { Republic }\end{array}$ \\
\hline $\mathrm{Th} / \mathrm{U}$ & 23.8 & 13 & 6.2 & 46.1 & 20 \\
$\mathrm{r}(\mathrm{U} / \mathrm{Th})$ & 0.042 & 0.077 & 0.161 & 0.022 & 0.05
\end{tabular}

The ${ }^{230} \mathrm{Th} /{ }^{232} \mathrm{Th}$ ratio $=r(0,2)$ and is calculated from Eq. $1:$

\begin{tabular}{ccccc} 
India & Brazil & Florida beach sands & $\begin{array}{c}\text { South African } \\
\text { monazite rock }\end{array}$ & $\begin{array}{c}\text { Malagasay } \\
\text { Republic }\end{array}$ \\
\hline $7.07 \times 10^{-7}$ & $1.30 \times 10^{-6}$ & $2.71 \times 10^{-6}$ & $3.70 \times 10^{-7}$ & $8.41 \times 10^{-7}$
\end{tabular}

The thorium content in thorium nitrate pentahydrate is $40.7 \%$ by weight. In 1 MT of the $\mathrm{ThN}$, there is $407 \mathrm{~kg}$ of Th, of which ${ }^{230} \mathrm{Th}$ (in gm/MT ThN) is approximately
0.29
0.53
1.10
0.15
0.34

\section{WEIGHT PERCENT THORIUM-232}

Assume that the ${ }^{232}$ Th occurs in the concentration given above for South African monazite ore, Malagasy Republic ore, and Indian ore. Benedict, Pigford, and Levi (1981) give weight percent $\mathrm{ThO}_{2}$. This must be converted to weight percent ${ }^{232} \mathrm{Th}$. The mass of $\mathrm{ThO}_{2}$ is 
$264 \mathrm{amu}$ and the mass of ${ }^{232} \mathrm{Th}$ is $232 \mathrm{amu}$; thus, the weight percent $\mathrm{Th}$ is $(232 / 264)$ times the weight percent $\mathrm{ThO}_{2}$.

In the following equations, $w t \%_{232}$ is the weight percent of ${ }^{232} \mathrm{Th}$ in the ore, and $p p m_{232}$ is the concentration of ${ }^{232} \mathrm{Th}$ in the ore.

$$
\begin{array}{ll}
\mathrm{wt}_{232_{0}}=5.9\left(\frac{232}{264}\right) & \mathrm{wt} \%_{232_{0}}=5.185 \\
\mathrm{ppm}_{232_{0}}=\mathrm{wt} \%_{232_{0}} 10^{4} & \mathrm{ppm}_{232_{0}}=5.185 \times 10^{4} \\
\mathrm{wt} \%_{232_{1}}=8.75\left(\frac{232}{264}\right) & \mathrm{wt} \%_{232_{1}}=7.689 \\
\mathrm{ppm}_{232_{1}}=\mathrm{wt} \%_{232_{1}} 10^{4} & \mathrm{ppm}_{232_{1}}=7.689 \times 10^{4} \\
\mathrm{wt} \%_{2322}=8.88\left(\frac{232}{264}\right) & \mathrm{wt} \%_{232_{2}}=7.804 \\
\mathrm{ppm}_{232_{2}}=\mathrm{wt} \%_{232_{2}} 10^{4} &
\end{array}
$$

To establish an upper bound, it is assumed that the partitioning coefficients for ${ }^{230,234}$ Th equal 1.

The Hammond inventory contains $863,685 \mathrm{~kg}$ of domestic thorium nitrate, and the Curtis Bay inventory contains $1,507,339 \mathrm{~kg}$ of domestic thorium nitrate that originated from South African monazite ore.

$$
\mathrm{M}_{\mathrm{ThN}_{0}}=(863,685+1,507,339) \mathrm{kg} \quad \mathrm{M}_{\mathrm{ThN}_{0}}=2.371 \times 10^{6} \mathrm{~kg}
$$

The Hammond inventory contains no French thorium nitrate. The Curtis Bay inventory contains $627,256 \mathrm{~kg}$ French thorium nitrate that originated from Malagasy Republic ore.

$$
\mathrm{M}_{\mathrm{ThN}_{1}}=627,256 \mathrm{~kg} \quad \mathrm{M}_{\mathrm{ThN}_{1}}=6.273 \times 10^{5} \mathrm{~kg}
$$

The Hammond inventory contains no thorium nitrate from Indian ore, and the Curtis Bay inventory contains $218,556 \mathrm{~kg}$ that originated from Indian ore.

$$
\mathrm{M}_{\mathrm{ThH}_{2}}=218,556 \mathrm{~kg} \quad \mathrm{M}_{\mathrm{ThN}_{2}}=2.186 \times 10^{5} \mathrm{~kg}
$$




\section{WEIGHT PERCENT URANIUM-238}

Assume that the ${ }^{238} \mathrm{U}$ occurs in the ore at the concentrations given above for South African monazite ore, Malagasy Republic ore, and Indian ore. Benedict, Pigford, and Levi (1981) gives weight percent $\mathrm{U}_{3} \mathrm{O}_{8}$. This must be converted to weight percent ${ }^{238} \mathrm{U}$. The mass of $\mathrm{U}_{3} \mathrm{O}_{8}$ is $842 \mathrm{amu}$ and the mass of three ${ }^{238} \mathrm{U}$ atoms is $714 \mathrm{amu}$. Thus, the weight percent $\mathrm{U}$ is $(714 / 842)$ times the weight percent $\mathrm{U}_{3} \mathrm{O}_{8}$.

The weight percent of ${ }^{238} \mathrm{U}$ in the ore is given by $w t \%{ }_{238}$, and the concentration of ${ }^{238} \mathrm{U}$ in the ore is given by ppm $_{238}$.

$$
\begin{aligned}
& w t \%_{238_{0}}=0.12\left(\frac{714}{842}\right) \\
& \mathrm{wt} \%_{238_{0}}=0.102 \\
& \mathrm{ppm}_{238}=\mathrm{wt} \%_{230} 10^{4} \\
& \mathrm{ppm}_{288}=1.018 \times 10^{3} \\
& w t \%_{2381}=0.41\left(\frac{714}{842}\right) \\
& \mathrm{wt} \%_{238_{1}}=0.348 \\
& \mathrm{ppm}_{238_{1}}=\mathrm{wt} \%_{238_{1}} 10^{4} \\
& \mathrm{ppm}_{238_{1}}=3.477 \times 10^{3} \\
& w t \%_{2382}=0.35\left(\frac{714}{842}\right) \\
& \mathrm{wt} \%_{238_{2}}=0.297 \\
& \operatorname{ppm}_{238_{2}}=w t \%_{238_{2}} 10^{4} \\
& \mathrm{ppm}_{238_{2}}=2.968 \times 10^{3}
\end{aligned}
$$

\section{RATIO OF THORIUM TO URANIUM}

The ratio of thorium to uranium in the ore is given by $R_{T h U}$.

$$
\begin{aligned}
& \mathrm{j}=0 \ldots .2 \\
& \mathrm{R}_{\mathrm{ThU}_{\mathrm{j}}}=\frac{\mathrm{wt} \%_{232_{\mathrm{j}}}}{\mathrm{wt} \%_{238_{j}}} \quad \mathrm{R}_{\mathrm{ThU}}=\left(\begin{array}{l}
50.953 \\
22.117 \\
26.293
\end{array}\right)
\end{aligned}
$$




$$
\mathrm{R}_{\mathrm{UTh}}=\mathrm{R}_{\mathrm{ThU}}^{-1} \quad \mathrm{R}_{\mathrm{UTh}}=\left(\begin{array}{c}
0.02 \\
0.045 \\
0.038
\end{array}\right)
$$

\section{MASS OF URANIUM IN THE ORE}

$M_{\text {NatU }}$ is the mass of natural uranium in the ore. It is assumed to be all ${ }^{238} \mathrm{U}$. The mass of ${ }^{232} \mathrm{Th}$ in the ore, $M_{\text {ThOre }}$, would be the mass of the inventory times the mass ratio of ${ }^{232} \mathrm{Th}$ to thorium nitrate.

$$
\begin{aligned}
& M_{\text {Th0Te }}=M_{\text {ThW }} \frac{m_{\mathrm{Th} 232}}{m_{\mathrm{ThN}}} \\
& \mathrm{M}_{\text {Thore }}=\left(\begin{array}{l}
9.65 \times 10^{5} \\
2.553 \times 10^{5} \\
8.895 \times 10^{4}
\end{array}\right) \mathrm{kg} \quad \mathrm{M}_{\mathrm{HatU}_{\mathrm{j}}}=\frac{\mathrm{M}_{\mathrm{ThOTe}}}{\mathrm{R}_{\mathrm{ThU}_{\mathrm{j}}}} \quad \mathrm{M}_{\mathrm{HatJ}}=\left(\begin{array}{l}
1.894 \times 10^{4} \\
1.154 \times 10^{4} \\
3.383 \times 10^{3}
\end{array}\right) \mathrm{kg}
\end{aligned}
$$

This mass of uranium has an activity, $A_{N a t U}$, determined by its specific activity.

$$
\mathrm{A}_{\mathrm{NatU}}=\mathrm{SpA}_{\mathrm{U} 238} \mathrm{M}_{\mathrm{NatU}} \quad \mathrm{A}_{\mathrm{HatU}}=\left(\begin{array}{c}
6.367 \times 10^{12} \\
3.881 \times 10^{12} \\
1.137 \times 10^{12}
\end{array}\right) \mathrm{pCl}
$$

\section{THORIUM-230 ACTIVITY IN THE ORE}

The ${ }^{230} \mathrm{Th}$ activity in the ore, $A_{\text {Th230ore }}$, is equal to the ${ }^{238} \mathrm{U}$ activity in the ore, $A_{\text {Nat }}$, because of secular equilibrium.

$$
\mathrm{A}_{\text {Th230ore }}=\mathrm{A}_{\mathrm{NatU}} \quad \mathrm{A}_{\text {Th230ore }}=\left(\begin{array}{c}
6.367 \times 10^{12} \\
3.881 \times 10^{12} \\
1.137 \times 10^{12}
\end{array}\right) \mathrm{pCi}
$$


The mass of ${ }^{230} \mathrm{Th}$ carried over to the thorium nitrate may be computed from the activity of ${ }^{230} \mathrm{Th}$ in the inventory, $A_{\text {Th230ore }}$, and the specific activity of ${ }^{230} \mathrm{Th}, S p A_{\text {Th230 }}$.

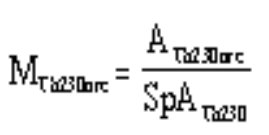

$$
\begin{aligned}
& \mathrm{M}_{\text {Th2300re }}=\left(\begin{array}{l}
0.309 \\
0.188 \\
0.055
\end{array}\right) \mathrm{kg} \\
& \mathrm{M}_{\mathrm{Th230 \text {inv }}}=\mathrm{M}_{\mathrm{Th230ore}} \\
& \mathrm{M}_{\mathrm{Th} 230 \mathrm{int}}=\left(\begin{array}{l}
0.309 \\
0.188 \\
0.055
\end{array}\right) \mathrm{kg} \\
& \mathrm{A}_{\text {Th230inv }}=\mathrm{A}_{\mathrm{Th230ore}} \\
& A_{\mathrm{Th} 230 \mathrm{nu}}=\left(\begin{array}{l}
6.367 \times 10^{12} \\
3.881 \times 10^{12} \\
1.137 \times 10^{12}
\end{array}\right) \mathrm{pCi} \\
& A_{\mathrm{Th} 230 \mathrm{amg}}=\frac{A_{\mathrm{Th} 230 \mathrm{in} j}}{M_{\mathrm{ThW} j}} \\
& A_{\text {Th230uvg }}=\left(\begin{array}{l}
2.685 \times 10^{3} \\
6.187 \times 10^{3} \\
5.204 \times 10^{3}
\end{array}\right) \frac{\mathrm{pCi}}{\mathrm{gm}}
\end{aligned}
$$

\begin{tabular}{|c|c|c|}
\hline \multicolumn{2}{|c|}{$\begin{array}{l}\text { Activities (in Bq) after } 42 \text { years assuming an } \\
\text { initial activity of } 1.0000 \times 10^{6} \mathrm{~Bq} \text { : }\end{array}$} & $\begin{array}{l}\text { Total activity (in Bq) after } 42 \text { years assuming an } \\
\text { initial activity of } 1.0000 \times 10^{6} \mathrm{~Bq} \text { : }\end{array}$ \\
\hline${ }^{230} \mathrm{Th}$ & $999.6 \times 10^{3}$ & ${ }^{230}$ Th series $\quad 1.131 \times 10^{6}$ \\
\hline${ }^{226} \mathrm{Ra}$ & $18.02 \times 10^{3}$ & \\
\hline${ }^{222} \mathrm{Rn}$ & $18.02 \times 10^{3}$ & \\
\hline${ }^{218} \mathrm{Po}$ & $18.02 \times 10^{3}$ & \\
\hline${ }^{214} \mathrm{~Pb}$ & $18.01 \times 10^{3}$ & \\
\hline${ }^{214} \mathrm{Bi}$ & $18.01 \times 10^{3}$ & \\
\hline${ }^{214} \mathrm{Po}$ & $18.01 \times 10^{3}$ & \\
\hline${ }^{210} \mathrm{~Pb}$ & $7.982 \times 10^{3}$ & \\
\hline${ }^{210} \mathrm{Bi}$ & $7.976 \times 10^{3}$ & \\
\hline${ }^{210} \mathrm{Po}$ & $7.806 \times 10^{3}$ & \\
\hline
\end{tabular}

For an initial ${ }^{230} \mathrm{Th}$ activity of $1.0000 \times 10^{6} \mathrm{~Bq}$, the following table displays the activities in the ${ }^{230} \mathrm{Th}$ decay sequence at 42 years:

Source: Data obtained from the World Information Service on Energy, universal decay calculator, URL: http://www.antenna.nl/wise/uranium/rcc.html, accessed April 10, 2002. 
From the data in the table, the activity of ${ }^{222} \mathrm{Rn}, A_{\text {Rn222Table }}$, after 42 years of ${ }^{230} \mathrm{Th}$ decay, is $18.02 \times 10^{-3}$ times the original activity of ${ }^{230} \mathrm{Th}, A_{\text {Th230inv }}$.

$$
\mathrm{A}_{\mathrm{Rn} 222 \mathrm{Table}}=18.02 \times 10^{-3} \mathrm{~A}_{\mathrm{Th} 230 \mathrm{inv}}
$$

$$
A_{\text {Fra2 Table }}=\left(\begin{array}{l}
1.147 \times 10^{11} \\
6.993 \times 10^{10} \\
2.05 \times 10^{10}
\end{array}\right) \mathrm{pCi}
$$

\section{CONCLUSIONS}

The calculated ${ }^{230} \mathrm{Th}$ activities per gram of thorium nitrate are as follows:

- $2.685 \times 10^{3} \mathrm{pCi} / \mathrm{gm}$ for ore mined in South Africa and processed in the United States,

- $6.187 \times 10^{3} \mathrm{pCi} / \mathrm{gm}$ for ore mined in the Malagasy Republic and processed in France, and

- $5.204 \times 10^{3} \mathrm{pCi} / \mathrm{gm}$ for ore mined and processed in India.

\section{REFERENCES}

Benedict, M., T.H. Pigford,and H.W. Levi (1981). Nuclear Chemical Engineering, 2nd ed., McGraw-Hill, New York.

UIC (Uranium Information Centre Ltd.) 1998. "Mineral Sands,” Nuclear Issues Briefing Paper 25, Melbourne, Australia, Jan. URL: http://www.uic.com.au/nip25.htm 
THIS PAGE INTENTIONALLY LEFT BLANK.

B-8 


\section{Appendix C}

\section{Thorium Sample Analysis Information}

\section{INTRODUCTION}

In the spring and summer of 2002, a sampling and analysis program was conducted for the thorium nitrate stockpile. Representative samples were sent to Southwest Research Institute (SWRI), a laboratory accredited by Nevada Test Site (NTS), where the samples were analyzed for chemical and radiological constituents. This appendix presents background information, measured radiological characteristics assigned to variables for detailed computations, and the resulting average values for selected characteristics.

\section{BACKGROUND}

The Hammond inventory contains $863,685 \mathrm{~kg}$ of domestic thorium nitrate, and the Curtis Bay inventory contains 1,507,339 $\mathrm{kg}$ of domestic thorium nitrate. Both inventories originated from South African monazite ore.

$$
\begin{array}{ll}
\mathrm{M}_{\mathrm{ThN}_{0}}=863,685 \mathrm{~kg} & \mathrm{M}_{\mathrm{ThH}}=8.637 \times 10^{5} \mathrm{~kg} \\
\mathrm{M}_{\mathrm{ThN} 1}=1,507,339 \mathrm{~kg} & \mathrm{M}_{\mathrm{ThN} 1}=1.507 \times 10^{6} \mathrm{~kg}
\end{array}
$$

The Hammond inventory contains no French thorium nitrate. The Curtis Bay inventory contains $627,256 \mathrm{~kg}$ of French thorium nitrate that originated from ore mined in the Malagasy Republic.

$$
\mathrm{M}_{\mathrm{ThH}_{2}}=627,256 \mathrm{~kg} \quad \mathrm{M}_{\mathrm{ThH} 2}=6.273 \times 10^{5} \mathrm{~kg}
$$

The Hammond inventory contains no thorium nitrate from Indian ore, and the Curtis Bay inventory contains $218,556 \mathrm{~kg}$ that originated from ore mined in India.

$$
\mathrm{M}_{\mathrm{ThW}_{3}}=218,556 \mathrm{~kg} \quad \mathrm{M}_{\mathrm{ThN}_{3}}=2.186 \times 10^{5} \mathrm{~kg}
$$

\section{HAMMOND DEPOT DOMESTIC—ICP/AES AND ICP/MS ANALYSES}

Among the radiological analyses completed by SWRI, the thorium nitrate from the Hammond Depot domestic (HD) inventory was first. The ratios of thorium and uranium mass to 
the mass of thorium nitrate, expressed in parts per million, were obtained using inductively coupled plasma/atomic emission spectroscopy (ICP/AES) and inductively coupled plasma/mass spectroscopy (ICP/MS) analyses, respectively, and are as follows.

$$
\begin{aligned}
& \operatorname{ppm}_{\mathrm{TL} 23 \mathrm{HD}}=\left(\begin{array}{l}
395,000 \\
387,000 \\
394,000 \\
391,000 \\
401,000 \\
391,000 \\
397,000 \\
394,000
\end{array}\right) \quad \operatorname{ppm}_{\mathrm{U} 238 \mathrm{HD}}=\left(\begin{array}{l}
0.42 \\
0.42 \\
0.44 \\
0.42 \\
0.43 \\
0.43 \\
0.41 \\
0.45
\end{array}\right) \\
& \operatorname{ppm}_{\text {Th232HDavg }}=\operatorname{mean}\left(\mathrm{ppm}_{\mathrm{Th} 232 \mathrm{HD}}\right) \quad \operatorname{ppm}_{\mathrm{Th} 232 \mathrm{HDavg}}=3.938 \times 10^{5} \\
& \operatorname{ppm}_{\mathrm{U} 238 \mathrm{HDavg}}=\operatorname{mean}\left(\mathrm{ppm}_{\mathrm{U} 238 \mathrm{HD}}\right) \quad \operatorname{ppm}_{\mathrm{U} 238 \mathrm{HDavg}}=4.275 \times 10^{-1}
\end{aligned}
$$

\section{HAMMOND DEPOT DOMESTIC-ALPHA SPECTROSCOPY}

The activity per gram of domestic thorium nitrate from Hammond Depot is given below for ${ }^{228} \mathrm{Th},{ }^{230} \mathrm{Th},{ }^{232} \mathrm{Th},{ }^{234} \mathrm{U},{ }^{235} \mathrm{U},{ }^{236} \mathrm{U},{ }^{238} \mathrm{U}$, and total $\mathrm{U}$. This information was obtained by SWRI using alpha spectroscopy.

$$
\begin{aligned}
& A_{\mathrm{T} 228 \mathrm{HD}}=\left(\begin{array}{l}
54,600 \\
49,200 \\
46,800
\end{array}\right) \frac{\mathrm{pCi}}{\mathrm{gm}} \quad \mathrm{A}_{\mathrm{T} 230 \mathrm{HD}}=\left(\begin{array}{l}
4,470 \\
3,570 \\
3,550
\end{array}\right) \frac{\mathrm{pCi}}{\mathrm{gm}} \quad \mathrm{A}_{\mathrm{T} 232 \mathrm{HD}}=\left(\begin{array}{l}
49,000 \\
44,500 \\
44,200
\end{array}\right) \frac{\mathrm{pCi}}{\mathrm{gm}} \\
& A_{\mathrm{U} 234 \mathrm{HD}}=\left(\begin{array}{l}
1.86 \\
1.32 \\
0.505
\end{array}\right) \frac{\mathrm{pCi}}{\mathrm{gm}} \quad A_{\mathrm{U} 235 \mathrm{HD}}=\left(\begin{array}{l}
0.0769 \\
0.000 \\
0.311
\end{array}\right) \frac{\mathrm{pCi}}{\mathrm{gm}} \quad A_{\mathrm{U} 236 \mathrm{HD}}=\left(\begin{array}{l}
0.133 \\
-0.064 \\
0.000
\end{array}\right) \frac{\mathrm{pCi}}{\mathrm{gm}} \\
& A_{\text {U238HD }}=\left(\begin{array}{l}
1.91 \\
0.835 \\
0.568
\end{array}\right) \frac{\mathrm{pCi}}{\mathrm{gm}} \quad A_{\text {TotaluHD }}=\left(\begin{array}{l}
3.98 \\
2.09 \\
1.38
\end{array}\right) \frac{\mathrm{pCi}}{\mathrm{gm}} \quad A_{\text {Total ThHD }}=\left(\begin{array}{l}
108,070 \\
97,270 \\
94,550
\end{array}\right) \frac{\mathrm{pCi}}{\mathrm{gm}}
\end{aligned}
$$


The ratio of thorium and uranium mass to mass of thorium nitrate from alpha spectroscopy analyses, in parts per million, are as follows:

$$
\begin{aligned}
& \operatorname{ppm}_{\text {Th232HD1 }}=\left(\begin{array}{l}
446,000 \\
405,000 \\
403,000
\end{array}\right) \\
& \mathrm{ppm}_{\text {Tot IJHD }}=\left(\begin{array}{l}
5.72 \\
2.48 \\
1.83
\end{array}\right) \\
& \operatorname{ppm}_{\text {Th232HD1avg }}=\operatorname{mean}\left(\operatorname{ppm}_{\mathrm{Th} 232 \mathrm{HD} 1}\right) \\
& \operatorname{ppm}_{\text {Th232HDlavg }}=4.180 \times 10^{5} \\
& \operatorname{ppm}_{\text {TotalUHD1 avg }}=\operatorname{mean}\left(\mathrm{ppm}_{\text {TotalUHD1 }}\right) \\
& \mathrm{ppm}_{\text {TotalUHD1 avg }}=3.343 \\
& \text { percent }_{\text {Th232HD1avg }}=\operatorname{ppm}_{\text {Th232HD1avg }} 10^{-4} \\
& \text { percent }_{\text {Th232HD1avg }}=41.8 \\
& \mathrm{~A}_{\text {Th232HDavg }}=\operatorname{mean}\left(\mathrm{A}_{\mathrm{Th} 232 \mathrm{HD}}\right) \\
& \mathrm{A}_{\text {Th232HDavg }}=4.59 \times 10^{4} \frac{\mathrm{pCi}}{\mathrm{gm}} \\
& \mathrm{A}_{\mathrm{U} 238 \mathrm{HDavg}}=\operatorname{mean}\left(\mathrm{A}_{\mathrm{U} 238 \mathrm{HD}}\right) \\
& \mathrm{A}_{\mathrm{U} 238 \mathrm{HDavg}}=1.104 \times 10^{0} \frac{\mathrm{pCi}}{\mathrm{gm}} \\
& \mathrm{A}_{\text {Th230HDavg }}=\operatorname{mean}\left(\mathrm{A}_{\mathrm{Th} 230 \mathrm{HD}}\right) \\
& \mathrm{A}_{\text {Th230HDavg }}=3.863 \times 10^{3} \frac{\mathrm{pCi}}{\mathrm{gm}}
\end{aligned}
$$

\section{CURTIS BAY DEPOT DOMESTIC - ICP/AES AND ICP/MS}

The radiological analysis of the Curtis Bay Depot domestic (CD) inventory was completed by SWRI. The ratios of thorium and uranium mass to the mass of thorium nitrate, expressed in parts per million, were obtained using ICP/AES and ICP/MS analyses, res pectively, and are as follows: 

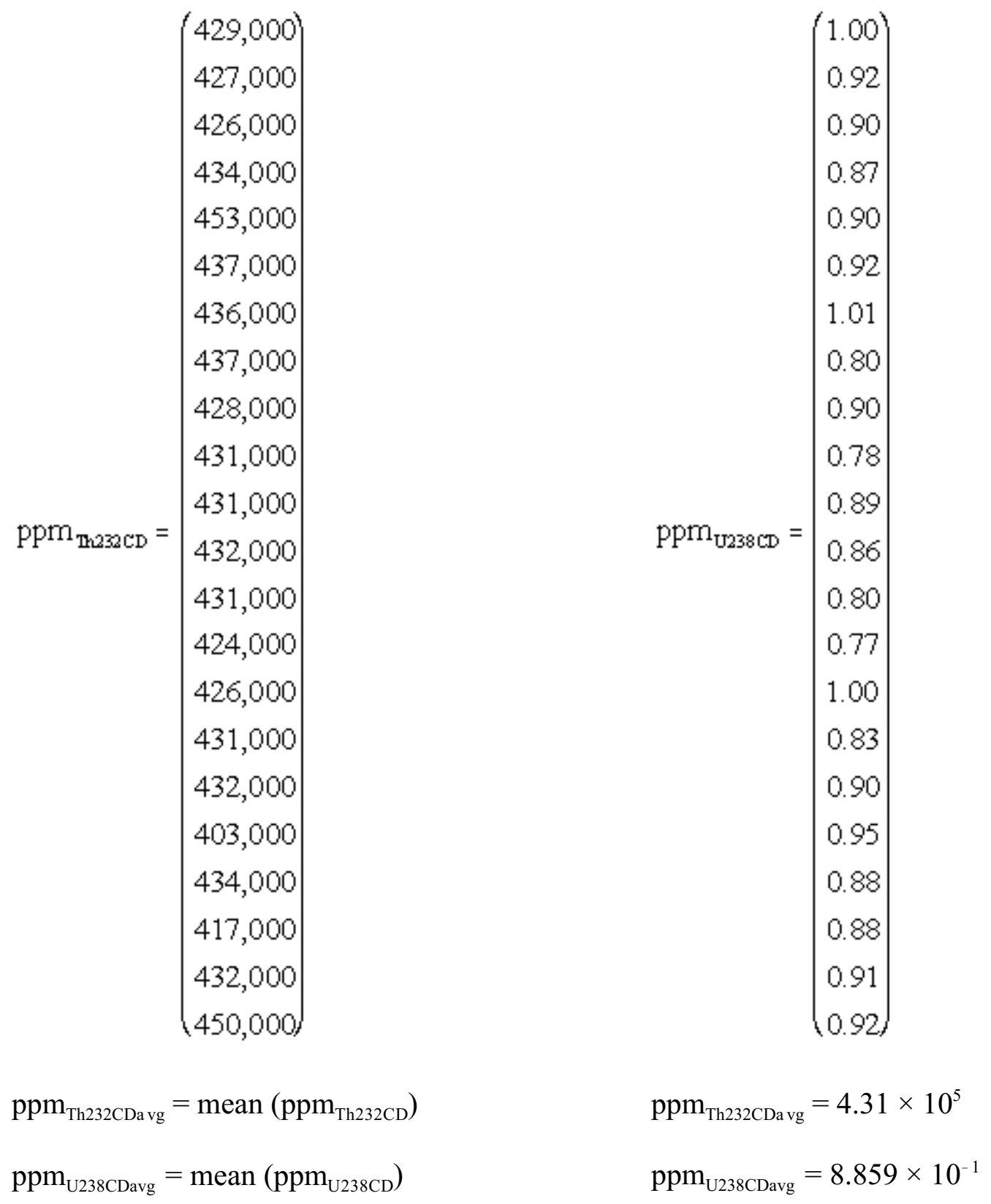

\section{CURTIS BAY DEPOT DOMESTIC-ALPHA SPECTROSCOPY}

Using alpha spectroscopy, SWRI obtained the activity per gram of domestic thorium nitrate from Curtis Bay Depot for ${ }^{228} \mathrm{Th},{ }^{230} \mathrm{Th},{ }^{232} \mathrm{Th},{ }^{234} \mathrm{U},{ }^{235} \mathrm{U},{ }^{236} \mathrm{U},{ }^{238} \mathrm{U}$, and total $\mathrm{U}$ : 


$$
A_{\text {Tr228d }}=\left(\begin{array}{l}
44,040 \\
46,190 \\
46,500 \\
50,810 \\
45,900 \\
45,910 \\
45,910 \\
45,740 \\
45,640
\end{array}\right) \frac{\mathrm{pCi}}{\mathrm{gm}}
$$

$A_{\mathrm{U} 234 \mathrm{CD}}=\left(\begin{array}{l}0.30 \\ 1.31 \\ 0.71 \\ 0.77 \\ 1.21 \\ 0.86 \\ 0.82 \\ 0.78 \\ 0.78\end{array}\right) \quad \frac{\mathrm{pCi}}{\mathrm{gm}}$

$A_{\mathrm{U} 238 \mathrm{CD}}=\left(\begin{array}{l}0.22 \\ 0.32 \\ 0.33 \\ 0.00 \\ 0.53 \\ 0.20 \\ 0.22 \\ 0.45 \\ 0.33\end{array}\right) \frac{\mathrm{pCi}}{\mathrm{gm}}$

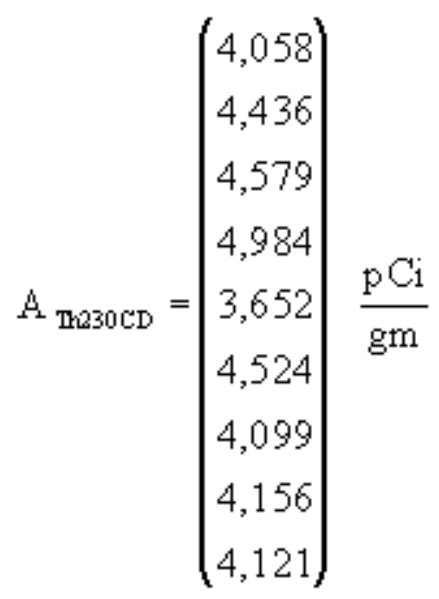

$A_{\text {Tr232CD }}=\left(\begin{array}{l}43,510 \\ 44,290 \\ 46,670 \\ 49,810 \\ 45,690 \\ 45,600 \\ 46,460 \\ 46,150 \\ 44,180\end{array}\right) \quad \frac{\mathrm{pCi}}{\mathrm{gm}}$

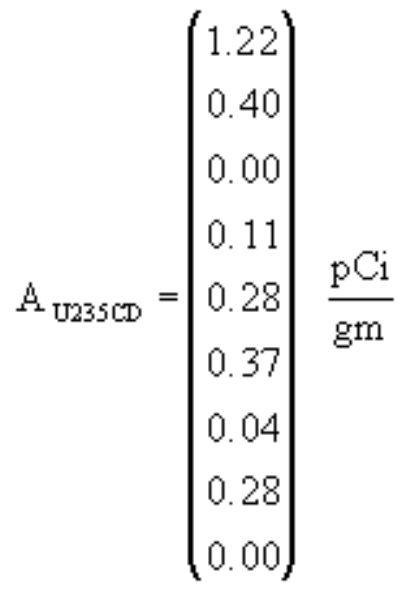

$A_{\mathrm{U} 236 \mathrm{CD}}=\left(\begin{array}{c}1.22 \\ 0.00 \\ 0.11 \\ 0.30 \\ 0.45 \\ 0.25 \\ 0.12 \\ 0.62 \\ 0.25\end{array}\right) \quad \frac{\mathrm{pCi}}{\mathrm{gm}}$

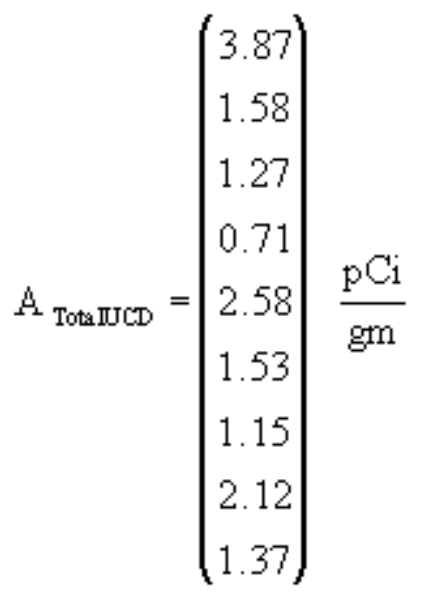


The ratio of thorium and uranium mass to the mass of thorium nitrate as determined by alpha spectroscopy analyses is as follows, in parts per million:

$\operatorname{ppm}_{\mathrm{Th} 23 \mathrm{CD} 1}=\left(\begin{array}{l}396,000 \\ 403,000 \\ 425,000 \\ 454,000 \\ 416,000 \\ 415,000 \\ 423,000 \\ 420,000 \\ 402,000\end{array}\right)$

$\operatorname{ppm}_{\mathrm{Th} 232 \mathrm{CD} 1 \mathrm{avg}}=\operatorname{mean}\left(\mathrm{ppm}_{\mathrm{Th} 232 \mathrm{CD} 1}\right)$

$\operatorname{ppm}_{\text {TotalUCD 1avg }}=\operatorname{mean}\left(\mathrm{ppm}_{\text {TotalUCD1 }}\right)$

percent $_{\mathrm{Th} 232 \mathrm{CD} 1 \text { avg }}=\operatorname{ppm}_{\mathrm{Th} 232 \mathrm{CD} 1 \text { avg }} 10^{-4}$

$\mathrm{A}_{\mathrm{Th} 232 \mathrm{CDavg}}=\operatorname{mean}\left(\mathrm{A}_{\mathrm{Th} 232 \mathrm{CD}}\right)$

$\mathrm{A}_{\mathrm{U} 238 \mathrm{CDavg}}=\operatorname{mean}\left(\mathrm{A}_{\mathrm{U} 238 \mathrm{CD}}\right)$

$\mathrm{A}_{\text {Th230CDavg }}=\operatorname{mean}\left(\mathrm{A}_{\mathrm{Th} 230 \mathrm{CD}}\right)$ $\operatorname{ppm}_{\text {TataluCD1 }}=\left(\begin{array}{l}1.24 \\ 1.14 \\ 1.00 \\ 0.06 \\ 1.72 \\ 0.77 \\ 0.67 \\ 1.46 \\ 1.00\end{array}\right)$

$\mathrm{ppm}_{\mathrm{Th232 \textrm {CD } 1 \mathrm { avg }}}=4.171 \times 10^{5}$

$\mathrm{ppm}_{\text {TotalUCD 1avg }}=1.007$

percent $_{\mathrm{Th232 \textrm {CD } 1 \mathrm { avg }}}=41.71$

$\mathrm{A}_{\text {Th232CDavg }}=4.582 \times 10^{4} \frac{\mathrm{pCi}}{\mathrm{gm}}$

$\mathrm{A}_{\mathrm{U} 238 \mathrm{CDavg}}=2.889 \times 10^{-1} \frac{\mathrm{pCi}}{\mathrm{gm}}$

$\mathrm{A}_{\text {Th230CDavg }}=4.290 \times 10^{3} \frac{\mathrm{pCi}}{\mathrm{gm}}$

\section{CURTIS BAY DEPOT FRENCH-ICP/AES AND ICP/MS}

The radiological analysis of the Curtis Bay Depot French (CF) inventory was completed by SWRI. The ratios of thorium and uranium mass to the mass of thorium nitrate, expressed in parts per million, were obtained using ICP/AES and ICP/MS analyses, respectively, and are as follows: 


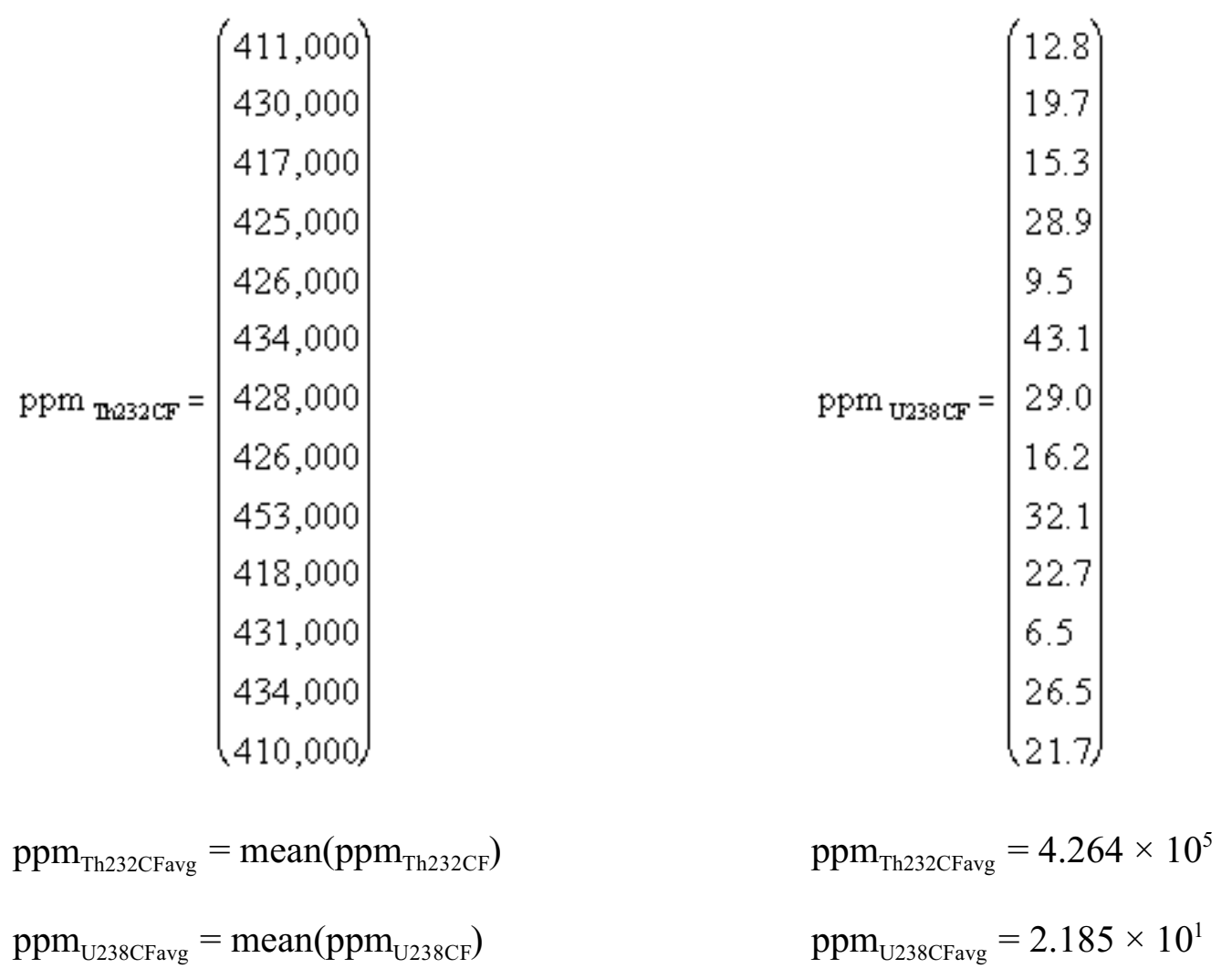

The activity per gram of French thorium nitrate from Curtis Bay Depot is given below for ${ }^{228} \mathrm{Th}$, ${ }^{230} \mathrm{Th},{ }^{232} \mathrm{Th},{ }^{234} \mathrm{U},{ }^{235} \mathrm{U},{ }^{236} \mathrm{U},{ }^{238} \mathrm{U}$, and total $\mathrm{U}$. This information was obtained by Southwest Res earch Institute using al pha spectroscopy.

$$
\begin{aligned}
& A_{\mathrm{T} 228 \mathrm{CF}}=\left(\begin{array}{l}
46,530 \\
43,080 \\
44,580
\end{array}\right) \frac{\mathrm{pCi}}{\mathrm{gm}} \quad \mathrm{A}_{\mathrm{Tr} 230 \mathrm{CF}}=\left(\begin{array}{c}
30,070 \\
49,950 \\
38,740
\end{array}\right) \frac{\mathrm{pCi}}{\mathrm{gm}} \quad A_{\mathrm{Tr} 232 \mathrm{CF}}=\left(\begin{array}{l}
41,220 \\
43,530 \\
45,440
\end{array}\right) \frac{\mathrm{pCi}}{\mathrm{gm}} \\
& A_{\mathrm{U} 234 \mathrm{CF}}=\left(\begin{array}{l}
7.83 \\
4.07 \\
14.48
\end{array}\right) \frac{\mathrm{pCi}}{\mathrm{gm}} \quad A_{\mathrm{U} 235 \mathrm{CF}}=\left(\begin{array}{l}
0.73 \\
0.12 \\
1.42
\end{array}\right) \frac{\mathrm{pCi}}{\mathrm{gm}} \quad A_{\mathrm{U} 236 \mathrm{CF}}=\left(\begin{array}{l}
0.33 \\
0.52 \\
0.46
\end{array}\right) \frac{\mathrm{pCi}}{\mathrm{gm}} \\
& A_{\text {U238CF }}=\left(\begin{array}{l}
8.65 \\
2.45 \\
14.23
\end{array}\right) \frac{\mathrm{pCi}}{\mathrm{gm}} \quad A_{\text {TotalucF }}=\left(\begin{array}{l}
17.54 \\
7.16 \\
30.6
\end{array}\right) \frac{\mathrm{pCi}}{\mathrm{gm}} \quad A_{\text {Total HCF }}=\left(\begin{array}{l}
114,370 \\
138,060 \\
130,710
\end{array}\right) \frac{\mathrm{pCi}}{\mathrm{gm}} \\
& \text { C-7 }
\end{aligned}
$$


The ratio of thorium and uranium mass to the mass of thorium nitrate from alpha spectroscopy analyses, in parts per million, are as follows:

$$
\begin{aligned}
& \operatorname{ppm}_{\operatorname{Th232CF} \alpha}=\left(\begin{array}{l}
375,000 \\
396,000 \\
414,000
\end{array}\right) \\
& \operatorname{ppm}_{\text {TotalucF }_{x}}=\left(\begin{array}{l}
26.09 \\
7.35 \\
43.02
\end{array}\right) \\
& \operatorname{ppm}_{\mathrm{Th} 232 \mathrm{CF} \alpha \mathrm{avg}}=\operatorname{mean}\left(\mathrm{ppm}_{\mathrm{Th232 \textrm {CF } 1}}\right) \quad \operatorname{ppm}_{\mathrm{Th} 232 \mathrm{CF} \alpha \mathrm{avg}}=3.95 \times 10^{5} \\
& \operatorname{ppm}_{\text {TotalUCFaavg }}=\operatorname{mean}\left(\mathrm{ppm}_{\text {TotalUCF1 }}\right) \quad \operatorname{ppm}_{\text {TotalUCFaavg }}=25.487 \\
& \text { percent }_{\text {Th232CFaavg }}=\operatorname{ppm}_{\text {Th232CFlavg }} 10^{-4} \quad \text { percent }_{\text {Th232CFaavg }}=39.5 \\
& \mathrm{~A}_{\text {Th232CFavg }}=\operatorname{mean}\left(\mathrm{A}_{\text {Th232CF }}\right) \quad \mathrm{A}_{\text {Th232CFavg }}=4.340 \times 10^{4} \frac{\mathrm{pCi}}{g m} \\
& \mathrm{~A}_{\mathrm{U} 238 \mathrm{CFavg}}=\operatorname{mean}\left(\mathrm{A}_{\mathrm{U} 238 \mathrm{CF}}\right) \quad \mathrm{A}_{\mathrm{U} 238 \mathrm{CFavg}}=8.443 \times 10^{\circ} \frac{\mathrm{pCi}}{\mathrm{gm}} \\
& \mathrm{A}_{\mathrm{Th} 230 \mathrm{CFavg}}=\operatorname{mean}\left(\mathrm{A}_{\mathrm{Th} 230 \mathrm{CF}}\right) \\
& \mathrm{A}_{\text {Th230CFavg }}=3.959 \times 10^{4} \frac{\mathrm{pCi}}{\mathrm{gm}}
\end{aligned}
$$

\section{CURTIS BAY DEPOT INDIAN-ICP/AES AND ICP/MS}

The radiological analysis of the Curtis Bay Depot Indian (CI) inventory was completed by SWRI. The ratios of thorium and uranium mass to the mass of thorium nitrate, in parts per million, were obtained using ICP/AES and ICP/MS analyses, respectively, and are as follows:

$$
\operatorname{ppm}_{\mathrm{Tr} 23 \mathrm{CI}}=\left(\begin{array}{l}
447,000 \\
469,000 \\
465,000 \\
445,000 \\
422,000 \\
442,000 \\
451,000 \\
444,000 \\
444,000 \\
447,000
\end{array}\right) \quad \mathrm{ppm}_{\mathrm{U} 23 \mathrm{sCI}}=\left(\begin{array}{c}
0.94 \\
0.79 \\
0.85 \\
0.93 \\
0.94 \\
0.89 \\
0.91 \\
0.93 \\
0.94 \\
0.93
\end{array}\right)
$$




$$
\begin{array}{ll}
\operatorname{ppm}_{\text {Th232Clavg }}=\operatorname{mean}\left(\mathrm{ppm}_{\text {Th232C }}\right) & \operatorname{ppm}_{\text {Th232Clavg }}=4.476 \times 10^{5} \\
\operatorname{ppm}_{\text {U238Clavg }}=\text { mean }\left(\mathrm{ppm}_{\text {U238C }}\right) & \operatorname{ppm}_{\text {U238Clavg }}=9.05 \times 10^{-1}
\end{array}
$$

\section{CURTIS BAY DEPOT INDIAN-ALPHA SPECTROSCOPY}

The activity per gram of Indian thorium nitrate from Curtis Bay Depot is given below for ${ }^{228} \mathrm{Th},{ }^{230} \mathrm{Th},{ }^{232} \mathrm{Th},{ }^{234} \mathrm{U},{ }^{235} \mathrm{U},{ }^{236} \mathrm{U},{ }^{238} \mathrm{U}$, and total $\mathrm{U}$. This information was obtained by SWRI using alpha spectroscopy:

$$
\begin{aligned}
& A_{\text {T2228CI }}=\left(\begin{array}{l}
47,330 \\
48,180 \\
49,880
\end{array}\right) \frac{p-i}{\mathrm{gm}} \quad A_{\mathrm{T} 230 \mathrm{CI}}=\left(\begin{array}{l}
7,532 \\
7,632 \\
7,450
\end{array}\right) \frac{\mathrm{pCi}}{\mathrm{gm}} \quad A_{\mathrm{T} 232 \mathrm{CI}}=\left(\begin{array}{l}
44,770 \\
44,580 \\
48,530
\end{array}\right) \frac{\mathrm{pCi}}{\mathrm{gm}} \\
& A_{\mathrm{U} 234 \mathrm{CT}}=\left(\begin{array}{l}
0.66 \\
0.35 \\
0.51
\end{array}\right) \frac{\mathrm{pCi}}{\mathrm{gm}} \quad \mathrm{A}_{\mathrm{U} 235 \mathrm{CT}}=\left(\begin{array}{l}
0.00 \\
0.03 \\
0.13
\end{array}\right) \frac{\mathrm{pCi}}{\mathrm{gm}} \quad \mathrm{A}_{\mathrm{U} 236 \mathrm{CT}}=\left(\begin{array}{l}
0.37 \\
0.10 \\
0.03
\end{array}\right) \frac{\mathrm{pCi}}{\mathrm{gm}} \\
& A_{\text {U238CT }}=\left(\begin{array}{l}
0.22 \\
0.02 \\
0.10
\end{array}\right) \frac{\mathrm{pCi}}{\mathrm{gm}} \quad \mathrm{A}_{\text {Tota IJCI }}=\left(\begin{array}{l}
1.25 \\
0.51 \\
0.77
\end{array}\right) \frac{\mathrm{pCi}}{\mathrm{gm}} \quad \mathrm{A}_{\text {Total IhCT }}=\left(\begin{array}{l}
99,632 \\
100,392 \\
105,860
\end{array}\right) \frac{\mathrm{pCi}}{\mathrm{gm}}
\end{aligned}
$$

The ratio of thorium and uranium mass to mass of thorium nitrate from alpha spectroscopy analyses, in parts per million, is as follows:

$$
\begin{aligned}
& \operatorname{ppm}_{\text {Th } 232 \text { CLe }}=\left(\begin{array}{l}
408,000 \\
406,000 \\
442,000
\end{array}\right) \quad \operatorname{ppm}_{\text {TatalUCLe }}=\left(\begin{array}{l}
0.66 \\
0.09 \\
0.36
\end{array}\right) \\
& \operatorname{ppm}_{\text {Th232CIaavg }}=\operatorname{mean}\left(\mathrm{ppm}_{\text {Th232C11 }}\right) \quad \operatorname{ppm}_{\text {Th232Claavg }}=4.187 \times 10^{5} \\
& \operatorname{ppm}_{\text {TotalUCIravg }}=\text { mean }\left(\mathrm{ppm}_{\text {TotalUCII }}\right) \quad \operatorname{ppm}_{\text {TotalUClaavg }}=0.37 \\
& \text { percent }_{\text {Th232CIaavg }}=\operatorname{ppm}_{\text {Th232CIlavg }} 10^{-4} \quad \text { percent }_{\text {Th232Claavg }}=41.87
\end{aligned}
$$




$$
\begin{array}{ll}
\mathrm{A}_{\text {Th232Clavg }}=\operatorname{mean}\left(\mathrm{A}_{\text {Th232CI }}\right) & \mathrm{A}_{\text {Th232Clavg }}=4.596 \times 10^{4} \frac{\mathrm{pCi}}{\mathrm{gm}} \\
\mathrm{A}_{\mathrm{U} 238 \text { Clavg }}=\operatorname{mean}\left(\mathrm{A}_{\mathrm{U} 238 \mathrm{CI}}\right) & \mathrm{A}_{\mathrm{U} 238 \mathrm{Clavg}}=1.133 \times 10^{-1} \frac{\mathrm{pCi}}{\mathrm{gm}} \\
\mathrm{A}_{\text {Th230Clavg }}=\operatorname{mean}\left(\mathrm{A}_{\text {Th230CI }}\right) & \mathrm{A}_{\text {Th230Clavg }}=7.538 \times 10^{3} \frac{\mathrm{pCi}}{\mathrm{gm}}
\end{array}
$$

\section{ACTIVITY CONCENTRATION}

The activity concentration - activity per unit volume - is obtained by multiplying the activity per unit mass by the density. The density measured by SWRI is $1.89 \mathrm{gm} / \mathrm{cm}^{3}$. The activity concentration is given by the symbol $C$ with the appropriate identifying subscripts.

$$
\begin{aligned}
& \rho_{\mathrm{ThN}}=1.89 \frac{\mathrm{gm}}{\mathrm{cm}^{3}} \\
& \mathrm{~A}_{\text {Th230HDavg }}=3.863 \times 10^{3} \frac{\mathrm{pCi}}{\mathrm{gm}} \quad \mathrm{C}_{230 \mathrm{HD}}=\mathrm{A}_{\text {Th230HDavg } \mathrm{ThN}} \quad \mathrm{C}_{230 \mathrm{HD}}=2.702 \times 10^{8} \frac{\mathrm{Bq}}{\mathrm{m}^{3}} \\
& \mathrm{~A}_{\text {Th230CDavg }}=4.290 \times 10^{3} \frac{\mathrm{pCi}}{\mathrm{gm}} \quad \mathrm{C}_{230 \mathrm{CD}}=\mathrm{A}_{\text {Th230CDavg } \mathrm{ThN}} \quad \mathrm{C}_{230 \mathrm{CD}}=3.00 \times 10^{8} \frac{\mathrm{Bq}}{\mathrm{m}^{3}} \\
& \mathrm{~A}_{\mathrm{Th} 230 \mathrm{CFavg}}=3.959 \times 10^{4} \frac{\mathrm{pCi}}{\mathrm{gm}} \quad \mathrm{C}_{230 \mathrm{CF}}=\mathrm{A}_{\mathrm{Th} 230 \mathrm{CFavg} \rho \mathrm{ThN}} \quad \mathrm{C}_{230 \mathrm{CF}}=2.768 \times 10^{9} \frac{\mathrm{Bq}}{\mathrm{m}^{3}} \\
& \mathrm{~A}_{\text {Th230Clavg }}=7.538 \times 10^{3} \frac{\mathrm{pCi}}{\mathrm{gm}} \quad \mathrm{C}_{230 \mathrm{CI}}=\mathrm{A}_{\text {Th230Clavg } \rho \mathrm{ThN}} \quad \mathrm{C}_{230 \mathrm{CI}}=5.271 \times 10^{8} \frac{\mathrm{Bq}}{\mathrm{m}^{3}}
\end{aligned}
$$

\section{CONCLUSIONS}

The average ${ }^{230} \mathrm{Th}$ activities per gram are as follows:

- $3.863 \times 10^{3} \mathrm{pCi} / \mathrm{gm}$ for ThN produced in the United States and stored at Hammond Depot,

- $4.290 \times 10^{3} \mathrm{pCi} / \mathrm{gm}$ for ThN produced in the United States and stored at Curtis Bay Depot,

- $\quad 39.59 \times 10^{3} \mathrm{pCi} / \mathrm{gm}$ for ThN produced in France and stored at Curtis Bay Depot, and

- $7.538 \times 10^{3} \mathrm{pCi} / \mathrm{gm}$ for ThN produced in India and stored at Curtis Bay Depot. 
The average ${ }^{230} \mathrm{Th}$ activity concentrations are as follows:

- $\quad 2.70 \times 10^{8} \mathrm{~Bq} / \mathrm{m}^{3}$ for ThN produced in the United States and stored at Hammond Depot, - $\quad 3.00 \times 10^{8} \mathrm{~Bq} / \mathrm{m}^{3}$ for ThN produced in the United States and stored at Curtis Bay Depot,

- $\quad 27.7 \times 10^{8} \mathrm{~Bq} / \mathrm{m}^{3}$ for ThN produced in France and stored at Curtis Bay Depot, and

- $\quad 5.27 \times 10^{8} \mathrm{~Bq} / \mathrm{m}^{3}$ for ThN produced in India and stored at Curtis Bay Depot. 


\section{THIS PAGE INTENTIONALLY LEFT BLANK.}




\section{Appendix D}

\section{Decay Calculations Using Ore Data}

\section{INTRODUCTION}

The Nevada Test Site (NTS) radon performance objective, $20 \mathrm{pCi} \cdot \mathrm{m}^{-2} \cdot \mathrm{sec}^{-1}$, applies to any time between the present and 1000 years in the future. Before the NTS model can be applied, the time-dependent levels of ${ }^{222} \mathrm{Rn}$ must be determined from potential ${ }^{222} \mathrm{Rn}$ sources: ${ }^{230} \mathrm{Th}$ and ${ }^{238} \mathrm{U}$. The ${ }^{230} \mathrm{Th}$ activities are computed from preliminary ore data, and the ${ }^{238} \mathrm{U}$ activities are computed from previously measured mass spectroscopic data.

This appendix presents background information; evaluates the potential sources of ${ }^{222} \mathrm{Rn}$; determines the time-dependent activities of ${ }^{230} \mathrm{Th},{ }^{226} \mathrm{Ra}$, and ${ }^{222} \mathrm{Rn}$; and compares the computed ${ }^{232} \mathrm{Th},{ }^{230} \mathrm{Th}$ and ${ }^{226} \mathrm{Ra}$ activities to NTS action levels.

The density, $\rho_{T h N}$, of the thorium nitrate is $1.65 \mathrm{gm} / \mathrm{cm}^{3}$.

$$
\rho_{\mathrm{ThN}}=1.65 \frac{\mathrm{gm}}{\mathrm{cm}^{3}}
$$

$$
\mathrm{Vol}_{\mathrm{ThN}}=\frac{\mathrm{M}_{\mathrm{ThW}}}{\rho_{\mathrm{TWH}}} \quad \mathrm{Vol}_{\mathrm{ThN}}=\left(\begin{array}{c}
1.437 \times 10^{3} \\
3.802 \times 10^{2} \\
1.325 \times 10^{2}
\end{array}\right) \mathrm{m}^{3}
$$

$\mathrm{Vol}_{T h N}$ is the volume of the thorium nitrate only. It does not include the volume of the drums.

\section{POSSIBLE SOURCES OF RADON-222}

There are two possible sources of ${ }^{222} \mathrm{Rn}$ in the thorium nitrate inventory: ${ }^{230} \mathrm{Th}$ and ${ }^{238} \mathrm{U}$ carried over into the thorium nitrate during chemical processing. All the available ${ }^{230} \mathrm{Th}$ is assumed to have been processed into the thorium nitrate. The ${ }^{238} \mathrm{U}$ is an impurity and is assumed to occur at $1 \mathrm{ppm}$, the level measured earlier by Oak Ridge National Laboratory.

$$
\begin{aligned}
& \operatorname{ppm}_{238 \mathrm{Mnx}}=1.00 \frac{\mathrm{mg}}{\mathrm{kg}} \\
& \mathrm{M}_{238}=\sum_{\mathrm{j}} \mathrm{M}_{\mathrm{ThN}} \mathrm{ppm}_{238 \mathrm{Mx}}
\end{aligned}
$$$$
\mathrm{M}_{\mathrm{ThW}}=\left(\begin{array}{l}
2.371 \times 10^{6} \\
6.273 \times 10^{5} \\
2.186 \times 10^{5}
\end{array}\right) \mathrm{kg}
$$

$\mathrm{M}_{238}=3.217 \mathrm{~kg}$ 
The total ${ }^{238} \mathrm{U}$ activity is given by $A_{238}=S p A_{U 238} M_{238} . \quad \mathrm{A}_{238}=1.081 \times 10^{9} \mathrm{pCi}$

The ${ }^{222} \mathrm{Rn}$ activity may be obtained from readily available decay calculators.

For an initial ${ }^{238} \mathrm{U}$ activity of $1.000 \times 10^{6} \mathrm{~Bq}$, the following table displays the activities in the ${ }^{238} \mathrm{U}$ decay sequence at 1000 years:

\begin{tabular}{|c|c|c|}
\hline \multicolumn{2}{|c|}{$\begin{array}{l}\text { Activities (in Bq) after } 1000 \text { years assuming } \\
\text { an initial activity of } 1.000 \times 10^{6} \mathrm{~Bq} \text { : }\end{array}$} & $\begin{array}{l}\text { Total activity (in Bq) after } 1000 \text { years assuming } \\
\text { an initial activity of } 1.000 \times 10^{6} \mathrm{~Bq} \text { : }\end{array}$ \\
\hline${ }^{238} \mathrm{U}$ & $1.000 \times 10^{6}$ & ${ }^{238} \mathrm{U}$ series $\quad 3.003 \times 10^{6}$ \\
\hline${ }^{234} \mathrm{Th}$ & $1.000 \times 10^{6}$ & \\
\hline${ }^{234 \mathrm{~m}} \mathrm{~Pa}$ & $1.000 \times 10^{6}$ & \\
\hline${ }^{234} \mathrm{U}$ & $2.826 \times 10^{3}$ & \\
\hline${ }^{230} \mathrm{Th}$ & 12.86 & \\
\hline${ }^{226} \mathrm{Ra}$ & 1.651 & \\
\hline${ }^{222} \mathrm{Rn}$ & 1.651 & \\
\hline${ }^{218} \mathrm{Po}$ & 1.651 & \\
\hline${ }^{214} \mathrm{~Pb}$ & 1.650 & \\
\hline${ }^{214} \mathrm{Bi}$ & 1.650 & \\
\hline${ }^{214} \mathrm{Po}$ & 1.650 & \\
\hline${ }^{210} \mathrm{~Pb}$ & 1.505 & \\
\hline${ }^{210} \mathrm{Bi}$ & 1.505 & \\
\hline${ }^{210} \mathrm{Po}$ & 1.503 & \\
\hline
\end{tabular}

Source: Data obtained from the World Information Service on Energy, universal decay calculator, URL: http://www.antenna.nl/wise/uranium/rcc.html, accessed April 10, 2002.

From the decay information presented above, the decay of ${ }^{238} \mathrm{U}$ in the thorium nitrate inventory would produce a ${ }^{222} \mathrm{Rn}$ activity at 1000 years that is $1.651 \times 10^{-6}$ the activity of the ${ }^{238} \mathrm{U}$.

$$
\mathrm{A}_{222 \text { fromU238 }}=\mathrm{A}_{238} 1.65110^{-6} \quad \mathrm{~A}_{222 \text { fromU238 }}=1.786 \times 10^{3} \mathrm{pCi}
$$

\section{CURRENT THORIUM-230 ACTIVITIES}

The original number of ${ }^{230} \mathrm{Th}$ atoms in the thorium nitrate inventory is given by $N_{\text {Th230inv }}$.

$$
\mathrm{N}_{\mathrm{Th} 230 \mathrm{inv}}=\frac{A_{\mathrm{Th} 230 \mathrm{in}}}{\lambda_{\mathrm{Th} 230}} \quad \mathrm{~N}_{\mathrm{Th} 230 \mathrm{inv}}=\left(\begin{array}{l}
8.082 \times 10^{23} \\
4.926 \times 10^{23} \\
1.444 \times 10^{23}
\end{array}\right)
$$


The mass of ${ }^{230} \mathrm{Th}$ in the thorium nitrate inventory is given by $M_{\text {Th230inv }}$.

$$
\begin{aligned}
& \mathrm{M}_{\mathrm{Th230 \textrm {inT }}}=\frac{\mathrm{N}_{\mathrm{T} 230 \mathrm{in}}}{\mathrm{N}_{\mathrm{A}}} \mathrm{m}_{\mathrm{Th} 230} \quad \mathrm{M}_{\mathrm{Th} 230 \mathrm{in}}=\left(\begin{array}{c}
3.087 \times 10^{-1} \\
1.881 \times 10^{-1} \\
5.513 \times 10^{-2}
\end{array}\right) \mathrm{kg} \\
& \mathrm{m}_{\text {totalTh230ino }}=\sum_{\mathrm{j}} \mathrm{M}_{\text {Th230in } \mathrm{j}} \quad \mathrm{m}_{\text {totalTh230inv }}=5.519 \times 10^{-1} \mathrm{~kg}
\end{aligned}
$$

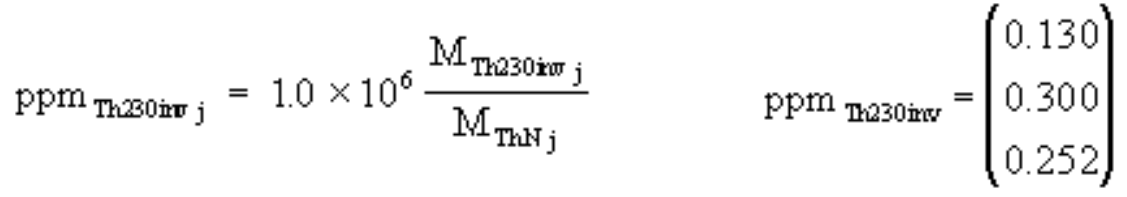

\section{THORIUM-230 AS A FUNCTION OF TIME}

The ${ }^{230}$ Th content of the inventory, which varies with time, is given by $A_{T h 230}(t)$,

$$
A_{\text {Th230 }}(t, j)=A_{\text {Th230inj } j} e^{-\lambda \operatorname{Th} 230 t}
$$

Changes in ${ }^{230} \mathrm{Th}$ activity are evaluated for $100,1,000,10,000$, and 100,000 years after separation from the ore. The ${ }^{230} \mathrm{Th}$ produced by each ore type is computed separately.

$$
\begin{aligned}
& \mathrm{t}=\left(\begin{array}{l}
100 \\
1,000 \\
10,000 \\
100,000
\end{array}\right) \mathrm{y} \quad \mathrm{i}=0 . .3 \quad \mathrm{~A}_{\mathbb{T} 230}\left(\mathrm{t}_{\mathrm{i}}, 0\right)=\left(\begin{array}{c}
6.361 \times 10^{12} \\
6.309 \times 10^{12} \\
5.808 \times 10^{12} \\
2.539 \times 10^{12}
\end{array}\right) \mathrm{pCi} \\
& A_{\operatorname{T} 230}\left(t_{i}, 1\right)=\left(\begin{array}{l}
3.877 \times 10^{12} \\
3.845 \times 10^{12} \\
3.54 \times 10^{12} \\
1.548 \times 10^{12}
\end{array}\right) \mathrm{pCi} \quad A_{T_{2} 30}\left(t_{i}, 2\right)=\left(\begin{array}{l}
1.136 \times 10^{12} \\
1.127 \times 10^{12} \\
1.037 \times 10^{12} \\
4.536 \times 10^{11}
\end{array}\right) \mathrm{pCi}
\end{aligned}
$$


The ${ }^{230} \mathrm{Th}$ contained in a gram of the thorium nitrate inventory is given by $\operatorname{Sp} A_{230 T h N}(t, j)$; $(j=0,1,2)$ refers to South African monazite ore, Malagasy Republic ore, and Indian ore, respectively,

$$
\operatorname{SpA}_{230 \mathrm{THN}}(t, j)=\frac{A_{\mathbb{T} 230}(t, j)}{M_{\mathbb{T H} j}}
$$

The variation with time of the ${ }^{230} \mathrm{Th}$ activity per gram in the thorium nitrate inventory is given by $S p A_{230 T h N}$. The times are 100,1,000,10,000, and 100,000 years after separation.

$$
\begin{aligned}
\mathrm{SpA}_{230 \mathrm{TWN}}\left(\mathrm{t}_{\mathrm{i}}, 0\right) & \left(\begin{array}{l}
2.683 \times 10^{3} \\
2.661 \times 10^{3} \\
2.45 \times 10^{3} \\
1.071 \times 10^{3}
\end{array}\right) \frac{\mathrm{pCi}}{\mathrm{gm}} \quad \mathrm{SpA}_{230 \mathrm{Tw}}\left(\mathrm{t}_{\mathrm{i}}, 1\right)=\left(\begin{array}{l}
6.181 \times 10^{3} \\
6.13 \times 10^{3} \\
5.643 \times 10^{3} \\
2.467 \times 10^{3}
\end{array}\right) \frac{\mathrm{pCi}}{\mathrm{gm}} \\
\operatorname{SpA}_{230 \mathrm{TWN}}\left(\mathrm{t}_{\mathrm{i}}, 2\right) & =\left(\begin{array}{l}
5.199 \times 10^{3} \\
5.156 \times 10^{3} \\
4.747 \times 10^{3} \\
2.075 \times 10^{3}
\end{array}\right) \frac{\mathrm{pCi}}{\mathrm{gm}}
\end{aligned}
$$

\section{RADIUM-226 ACTIVITY AS A FUNCTION OF TIME}

The activity of ${ }^{226} \mathrm{Ra}$ as a function of time is given by $A_{R a 226}(t)$. A Bateman equation for two isotopes is used to compute the activity of ${ }^{226} \mathrm{Ra}$ assuming an original quantity of ${ }^{230} \mathrm{Th}$ and specified decay times.

$$
A_{\mathrm{Ra} 226}(t, j)=\frac{\lambda_{\mathrm{Ra} 226} A_{\mathrm{Th} 230 \mathbf{n w} j}}{\lambda_{\mathrm{Ra} 226}-\lambda_{\mathrm{Th} 230}}\left(\mathrm{e}^{-\lambda_{\mathrm{T} 230} \mathrm{t}}-\mathrm{e}^{-\mathrm{\lambda}_{\mathrm{Ra} 226} \mathrm{t}}\right)
$$

The times for evaluation of the ${ }^{226}$ Ra activity are 100, 1,000, 10,000, and 100,000 years after separation. The subscript $j(j=0,1,2)$ refers to South African monazite ore, Malagasy Republic ore, and Indian ore, respectively. 


$$
\begin{gathered}
A_{\mathrm{Ra} 226}\left(t_{1}, 0\right)=\left(\begin{array}{l}
2.698 \times 10^{11} \\
2.228 \times 10^{12} \\
5.848 \times 10^{12} \\
2.594 \times 10^{12}
\end{array}\right) \mathrm{pCi} \quad A_{\mathrm{Ra} 226}\left(t_{1}, 1\right)=\left(\begin{array}{l}
1.664 \times 10^{11} \\
1.358 \times 10^{11} \\
3.564 \times 10^{12} \\
1.581 \times 10^{12}
\end{array}\right) \mathrm{pCi} \\
\mathrm{A}_{\mathrm{Ra} 226}\left(\mathrm{t}_{\mathrm{i}}, 2\right)=\left(\begin{array}{l}
4.82 \times 10^{10} \\
3.979 \times 10^{11} \\
1.045 \times 10^{12} \\
4.634 \times 10^{11}
\end{array}\right) \mathrm{pCi}
\end{gathered}
$$

The variation with time of the ${ }^{226} \mathrm{Ra}$ activity per gram in the thorium nitrate inventory is given by $\operatorname{Sp}_{226 T h N}(t), \operatorname{SpA} A_{226 \mathrm{ThN}}(\mathrm{t}, \mathrm{j})=\frac{\mathrm{A}_{\mathrm{Ra}_{226}}(\mathrm{t}, \mathrm{j})}{\mathrm{M}_{\mathrm{ThN} j \mathrm{j}}}$ The times are 100, 1,000, 10,000, and 100,000 years after separation.

$$
\begin{aligned}
\mathrm{SpA}_{226 \mathrm{TWH}}\left(\mathrm{t}_{\mathrm{i}}, 0\right)= & \left(\begin{array}{l}
1.138 \times 10^{2} \\
9.395 \times 10^{2} \\
2.467 \times 10^{3} \\
1.094 \times 10^{3}
\end{array}\right) \frac{\mathrm{pCi}}{\mathrm{gm}} \quad \mathrm{SpA}_{226 \mathrm{TWH}}\left(\mathrm{t}_{\mathrm{i}}, 1\right)=\left(\begin{array}{l}
2.622 \times 10^{2} \\
2.164 \times 10^{3} \\
5.683 \times 10^{3} \\
2.521 \times 10^{3}
\end{array}\right) \frac{\mathrm{pCi}}{\mathrm{gm}} \\
\operatorname{SpA}_{226 \mathrm{ThN}}\left(\mathrm{t}_{\mathrm{i}}, 2\right) & =\left(\begin{array}{l}
2.205 \times 10^{2} \\
1.821 \times 10^{3} \\
4.78 \times 10^{3} \\
2.12 \times 10^{3}
\end{array}\right) \frac{\mathrm{pCi}}{\mathrm{gm}}
\end{aligned}
$$




\section{RADON-222 ACTIVITY AS A FUNCTION OF TIME}

The activity of ${ }^{222} \mathrm{Rn}$ as a function of time is given by $A_{R n 222}(t)$. A Bateman equation for three isotopes is used to compute the activity of ${ }^{222} \mathrm{Rn}$ assuming an original quantity of ${ }^{230} \mathrm{Th}$ and specified decay times. The coefficients of the Bateman equation are $C_{1}, C_{2}$, and $C_{3}$.

$$
\begin{aligned}
& \mathrm{C}_{1}=\left(\lambda_{\mathrm{Ra} 226}-\lambda_{\mathrm{Th} 230}\right)^{-1}\left(\lambda_{\mathrm{Rn} 222}-\lambda_{\mathrm{Th} 230}\right)^{-1} \quad \mathrm{C}_{1}=3.564 \times 10^{1} \mathrm{y}^{2} \\
& \mathrm{C}_{2}=\left(\lambda_{\text {Th230 }}-\lambda_{\text {Ra226 }}\right)^{-1}\left(\lambda_{\text {Rn222 }}-\lambda_{\text {Ra226 }}\right)^{-1} \quad \mathrm{C}_{2}=-3.564 \times 10^{1} \mathrm{y}^{2} \\
& \mathrm{C}_{3}=\left(\lambda_{\mathrm{Th} 230}-\lambda_{\mathrm{Rn} 222}\right)^{-1}\left(\lambda_{\mathrm{Ra} 226}-\lambda_{\mathrm{Rn} 222}\right)^{-1} \quad \mathrm{C}_{3}=2.284 \times 10^{-4} \mathrm{y}^{2} \\
& A_{\mathrm{Rn} 222}(t, j)=\lambda_{\mathrm{R} 226} \lambda_{\mathrm{Rr} 222} A_{\mathrm{Th} 230 \mathbf{n} \pi \mathrm{j}}\left(\mathrm{C}_{1} \mathrm{e}^{-\mathrm{\lambda}_{\mathrm{Th} 230 \mathrm{t}}}+\mathrm{C}_{2} \mathrm{e}^{-\lambda_{\mathrm{R} 2226 \mathrm{t}}}+\mathrm{C}_{3} \mathrm{e}^{-\lambda \mathrm{Rr} 222 \mathrm{t}}\right)
\end{aligned}
$$

For each ore type [South African monazite $(j=0)$, Malagasy Republic $(j=1)$, and Indian $(j=2)]$, the activities of ${ }^{222} \mathrm{Rn}$ at $100,1,000,10,000$, and 100,000 years after separation from the ore are as follows.

$$
\begin{gathered}
A_{\mathrm{Fr} 222}\left(\mathrm{t}_{\mathrm{i}}, 0\right)=\left(\begin{array}{c}
2.698 \times 10^{11} \\
2.228 \times 10^{12} \\
5.848 \times 10^{12} \\
2.594 \times 10^{12}
\end{array}\right) \mathrm{pCi} \quad \mathrm{A}_{\mathrm{Fr} 222}\left(\mathrm{t}_{\mathrm{i}}, 1\right)=\left(\begin{array}{l}
1.664 \times 10^{11} \\
1.358 \times 10^{12} \\
3.564 \times 10^{12} \\
1.581 \times 10^{12}
\end{array}\right) \mathrm{pCi} \\
\mathrm{A}_{\mathrm{Fr} 222}\left(\mathrm{t}_{\mathrm{i}}, 2\right)=\left(\begin{array}{l}
4.819 \times 10^{10} \\
3.979 \times 10^{11} \\
1.045 \times 10^{12} \\
4.634 \times 10^{11}
\end{array}\right) \mathrm{pCi}
\end{gathered}
$$

The time-dependent amount of ${ }^{222} \mathrm{Rn}$ contained in a gram of the thorium nitrate inventory is given by $A_{222 T h N}(t, j)$,

$$
A_{222 \mathrm{TH}}(t, j)=\frac{A_{\mathrm{Fr} 222}(t, j)}{M_{\mathrm{TH} j}}
$$


The evaluation times are 100,1,000,10,000, and 100,000 years after separation. The computations are performed, respectively, for South African monazite ore $(j=0)$, Malagasy Republic ore $(j=1)$, and Indian ore $(j=2)$.

$$
\begin{gathered}
A_{222 \mathrm{ThN}}\left(t_{i}, 0\right)=\left(\begin{array}{l}
1.138 \times 10^{2} \\
9.395 \times 10^{2} \\
2.467 \times 10^{3} \\
1.094 \times 10^{3}
\end{array}\right) \frac{\mathrm{pCi}}{\mathrm{gm}} \quad \mathrm{A}_{222 \mathrm{ThN}}\left(\mathrm{t}_{\mathrm{i}}, 1\right)=\left(\begin{array}{l}
2.621 \times 10^{2} \\
2.164 \times 10^{3} \\
5.683 \times 10^{3} \\
2.521 \times 10^{3}
\end{array}\right) \frac{\mathrm{pCi}}{\mathrm{gm}} \\
\mathrm{A}_{222 \mathrm{ThN}}\left(\mathrm{t}_{\mathrm{i}}, 2\right)=\left(\begin{array}{l}
2.205 \times 10^{2} \\
1.821 \times 10^{3} \\
4.78 \times 10^{3} \\
2.12 \times 10^{3}
\end{array}\right) \frac{\mathrm{pCi}}{\mathrm{gm}} \\
\mathrm{A}_{\text {222Total }}=\sum_{\mathrm{j}} \mathrm{A}_{222 \mathrm{ThN}}(1000 \mathrm{y}, \mathrm{j}) \quad \mathrm{A}_{222 \mathrm{Total}}=4.924 \times 10^{3} \frac{\mathrm{pCi}}{\mathrm{gm}}
\end{gathered}
$$

The ${ }^{222} \mathrm{Rn}$ generated by decay of ${ }^{230} \mathrm{Th}$, which was processed into the thorium nitrate directly from the ore, is given by $A_{222 T h 230}$.

$$
A_{222 \text { from Th230 }}=A_{222 \text { Toti } 1} \sum_{j} M_{T_{T H} j} \quad A_{222 \text { from Th230 }}=1.584 \times 10^{13} \mathrm{pCi}
$$

The ratio of ${ }^{222} \mathrm{Rn}$ activity resulting from decay of ${ }^{230} \mathrm{Th}$ to ${ }^{222} \mathrm{Rn}$ activity resulting from decay of ${ }^{238} \mathrm{U}$ is given by $R_{230 t o 238}$.

$$
\mathrm{R}_{230 \mathrm{to} 238}=\frac{\mathrm{A}_{222 \mathrm{from} T \mathrm{Th} 20}}{\mathrm{~A}_{222 \mathrm{frm} \mathrm{m} \text { L238 }}} \quad \mathrm{R}_{230 \mathrm{to} 238}=8.872 \times 10^{9}
$$

\section{THORIUM-232 ACTION LEVEL}

The ${ }^{232} \mathrm{Th}$ action level cited in Rev. 4 to the NTS Waste Acceptance Criteria (DOE 2002) is $8.1 \times 10^{8} \mathrm{~Bq} / \mathrm{m}^{3}$. 
The ${ }^{232} \mathrm{Th}$ concentration in the thorium nitrate inventory is given by $C_{T h 232}=S p A_{T h N} \rho_{T h N}$.

$$
\mathrm{C}_{\mathrm{Th} 232}=2.736 \times 10^{9} \frac{\mathrm{Bq}}{\mathrm{m}^{3}} \quad \mathrm{C}_{\text {Action232 }}=8.1 \times 10^{8} \frac{\mathrm{Bq}}{\mathrm{m}^{3}}
$$

The ratio of the volume activity of the thorium nitrate inventory to the NTS action level is given by

$$
\mathrm{R}_{\mathrm{CtoA}}=\frac{\mathrm{C}_{\mathrm{Th232}}}{\mathrm{C}_{\mathrm{Attin} 232}} \quad \mathrm{R}_{\mathrm{CtoA}}=3.378
$$

\section{THORIUM-230 ACTION LEVEL}

The ${ }^{230}$ Th action level cited in Rev. 4 to the NTS Waste Acceptance Criteria (DOE 2002) is $9.6 \times 10^{7} \mathrm{~Bq} / \mathrm{m}^{3}$. The concentration of ${ }^{230} \mathrm{Th}$ in the thorium nitrate inventory varies with time,

$$
\mathrm{C}_{230}(t, j)=\frac{A_{\mathrm{Th} 230}(t, j) \rho_{\mathrm{ThW}}}{\mathrm{M}_{\mathrm{ThH} j}}
$$

where $(j=0,1,2)$ refers to South African monazite ore, Malagasy Republic ore, and Indian ore, respectively.

$$
\begin{gathered}
\mathrm{C}_{230}\left(\mathrm{t}_{\mathrm{i}}, 0\right)=\left(\begin{array}{l}
1.638 \times 10^{8} \\
1.624 \times 10^{8} \\
1.495 \times 10^{8} \\
6.538 \times 10^{7}
\end{array}\right) \frac{\mathrm{Bq}}{\mathrm{m}^{3}} \quad \mathrm{C}_{230}\left(\mathrm{t}_{\mathrm{i}}, 1\right)=\left(\begin{array}{l}
3.773 \times 10^{8} \\
3.742 \times 10^{8} \\
3.445 \times 10^{8} \\
1.506 \times 10^{8}
\end{array}\right) \frac{\mathrm{Bq}}{\mathrm{m}^{3}} \\
\mathrm{C}_{230}\left(\mathrm{t}_{\mathrm{i}}, 2\right)=\left(\begin{array}{l}
3.174 \times 10^{8} \\
3.148 \times 10^{8} \\
2.898 \times 10^{8} \\
1.267 \times 10^{8}
\end{array}\right) \frac{\mathrm{Bq}}{\mathrm{m}^{3}} \\
\mathrm{C}_{\text {Action } 230}=9.6 \times 10^{7} \frac{\mathrm{Bq}}{\mathrm{m}^{3}}
\end{gathered}
$$


The variation with time of the ratio of the ${ }^{230} \mathrm{Th}$ concentration in the thorium nitrate inventory to the NTS action level for ${ }^{226} \mathrm{Ra}$ is given by

$$
R_{C T 230}(t, j)=\frac{C_{230}(t, j)}{C_{\text {Action } 230}}
$$

The times are 100,1,000,10,000, and 100,000 years after separation. The subscript $j(j=0,1,2)$ refers to South African monazite ore, Malagasy Republic ore, and Indian ore, respectively.

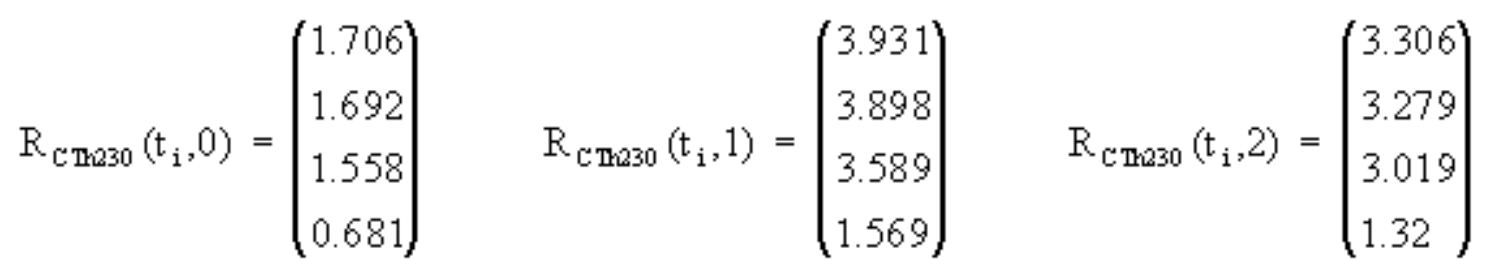

\section{RADIUM-226 ACTION LEVEL}

The ${ }^{226} \mathrm{Ra}$ action level cited in Rev. 4 to the NTS Waste Acceptance Criteria (DOE 2002) is $3.6 \times 10^{7} \mathrm{~Bq} / \mathrm{m}^{3}$.

$$
\mathrm{C}_{\text {Antion } 226}=3.6 \times 10^{7} \frac{\mathrm{Bq}}{\mathrm{m}^{3}}
$$

The concentration of ${ }^{226} \mathrm{Ra}$ in the thorium nitrate inventory varies with time,

$$
\mathrm{C}_{226}(\mathrm{t}, \mathrm{j})=\frac{\mathrm{A}_{\mathrm{R} 226}(\mathrm{t}, \mathrm{j}) \rho_{\mathrm{ThW}}}{\mathrm{M}_{\mathrm{ThW} j}}
$$

where $\mathrm{t}=100,1,000,10,000$, and 100,000 years after separation from the ore.

$$
\mathrm{C}_{226}\left(\mathrm{t}_{i}, 0\right)=\left(\begin{array}{l}
6.9 \times 10^{6} \\
5.7 \times 10^{7} \\
1.5 \times 10^{8} \\
6.7 \times 10^{7}
\end{array}\right) \quad \frac{\mathrm{Bq}}{\mathrm{m}^{3}} \quad \mathrm{C}_{226}\left(\mathrm{t}_{\mathrm{i}}, 1\right)=\left(\begin{array}{l}
1.6 \times 10^{7} \\
1.3 \times 10^{8} \\
3.5 \times 10^{8} \\
1.5 \times 10^{8}
\end{array}\right) \frac{\mathrm{Bq}}{\mathrm{m}^{3}}
$$




$$
\mathrm{C}_{226}\left(\mathrm{t}_{\mathrm{i}}, 2\right)=\left(\begin{array}{l}
1.3 \times 10^{7} \\
1.1 \times 10^{8} \\
2.9 \times 10^{8} \\
1.3 \times 10^{8}
\end{array}\right) \quad \frac{\mathrm{Bq}}{\mathrm{m}^{3}}
$$

The variation with time of the ratio of the ${ }^{226} \mathrm{Ra}$ concentration in the thorium nitrate inventory to the NTS action level is given by

$$
R_{226}(t, j)=\frac{C_{226}(t, j)}{C_{\text {Attion } 226}}
$$

The times are 100,1,000,10,000, and 100,000 years after separation. For each ore (South African monazite, Malagasy Republic, and Indian), between 100 and 1000 years, the increasing ratio reaches and exceeds 1 ; when this occurs, the ${ }^{226} \mathrm{Ra}$ concentration is no longer compliant with the NTS action level.

$$
\begin{gathered}
R_{226}\left(t_{i}, 0\right)=\left(\begin{array}{l}
0.193 \\
1.593 \\
4.183 \\
1.855
\end{array}\right) \quad R_{226}\left(t_{i}, 1\right)=\left(\begin{array}{l}
0.445 \\
3.67 \\
9.637 \\
4.275
\end{array}\right) \quad R_{226}\left(t_{i}, 2\right)=\left(\begin{array}{l}
0.374 \\
3.087 \\
8.106 \\
3.596
\end{array}\right) \\
R_{226 \text { total }}=\sum_{j} R_{226}(t, j) \quad R_{226 \text { total }}=\left(\begin{array}{l}
1.012 \\
8.351 \\
21.925 \\
9.726
\end{array}\right)
\end{gathered}
$$

The activity concentration of ${ }^{226} \mathrm{Ra}$ in the thorium nitrate will be slightly in excess of the NTS action level at 100 years. The activity of ${ }^{226} \mathrm{Ra}$ increases with time until roughly 10,000 years; the current activity concentration of ${ }^{226} \mathrm{Ra}$ is less than the NTS action level.

\section{CONCLUSIONS}

The constituents of the thorium nitrate determined from ore data are near or well above the applicable NTS action levels. The current activity concentration of ${ }^{232} \mathrm{Th}$ in the thorium nitrate inventory is about 4.2 times the NTS action level. The current activity concentration of 
${ }^{230} \mathrm{Th}$ in the thorium nitrate inventory is about 10.1 times the NTS action level. The current activity concentration of ${ }^{226} \mathrm{Ra}$ is less than the NTS action level.

The decay of ${ }^{238} \mathrm{U}$ is an insignificant source of ${ }^{222} \mathrm{Rn}$ in the thorium nitrate inventory. At 1000 years, over 8.9 billion times more ${ }^{222} \mathrm{Rn}$ results from the decay of ${ }^{230} \mathrm{Th}$ that was present in the original ore body than from the decay of ${ }^{238} \mathrm{U}$.

\section{REFERENCES}

DOE (U.S. Department of Energy) 2002. Nevada Test Site Waste Acceptance Criteria, DOE/NV-325-Rev. 4, Nevada Operations Office, Waste Management Division, Feb. URL: http://www.nv.doe.gov/programs/envmgmt/RWAP/pdfs/DOENV325_REV4.pdf 
THIS PAGE INTENTIONALLY LEFT BLANK.

D-12 


\section{Appendix E}

\section{Decay Calculations Using Recent Data}

\section{INTRODUCTION}

The Nevada Test Site (NTS) radon performance objective, $20 \mathrm{pCi} \cdot \mathrm{m}^{-2} \cdot \mathrm{sec}^{-1}$, applies to any time between the present and 1000 years in the future. Before the NTS model can be applied, the time-dependent levels of ${ }^{222} \mathrm{Rn}$ must be determined. These calculations use recent measurements of ${ }^{230} \mathrm{Th}$ and ${ }^{238} \mathrm{U}$, potential ${ }^{222} \mathrm{Rn}$ sources, made by Southwest Research Institute (SWRI). This appendix presents background information; evaluates the potential sources of ${ }^{222} \mathrm{Rn}$; determines the time-dependent activities of ${ }^{230} \mathrm{Th},{ }^{226} \mathrm{Ra}$, and ${ }^{222} \mathrm{Rn}$; and compares the computed ${ }^{232} \mathrm{Th},{ }^{230} \mathrm{Th}$, and ${ }^{226} \mathrm{Ra}$ activities to NTS action levels.

\section{BACKGROUND}

The measured density, $\rho_{T h N}$, of the thorium nitrate is $1.89 \mathrm{gm} / \mathrm{cm}^{3} . \quad \rho_{\mathrm{ThN}}=1.89 \frac{\mathrm{gm}}{\mathrm{cm}^{3}}$

$$
\begin{gathered}
\mathrm{Vol}_{\mathrm{ThW}}=\frac{\mathrm{M}_{\mathrm{ThN}}}{\rho_{\mathrm{ThN}}} \quad \mathrm{Vol}_{\mathrm{ThN}}=\left(\begin{array}{c}
4.57 \times 10^{2} \\
7.975 \times 10^{2} \\
3.319 \times 10^{2} \\
1.156 \times 10^{2}
\end{array}\right) \mathrm{m}^{3} \quad \mathrm{j}=0 . .3 \\
\mathrm{Vol}=\sum_{\mathrm{j}} \mathrm{Vol}_{\mathrm{ThN}_{\mathrm{j}}} \\
\mathrm{Vol}=1.702 \times 10^{3} \mathrm{~m}^{3}
\end{gathered}
$$

$\mathrm{Vol}_{T h N}$ is the volume of the thorium nitrate only. It does not include the volume of the drums.

\section{POSSIBLE SOURCES OF RADON-222}

There are two possible sources of ${ }^{222} \mathrm{Rn}$ in the thorium nitrate inventory: ${ }^{230} \mathrm{Th}$ and ${ }^{238} \mathrm{U}$ carried over into the thorium nitrate during chemical processing. All the available ${ }^{230} \mathrm{Th}$ is assumed to have been processed into the thorium nitrate. The ${ }^{238} \mathrm{U}$ is an impurity and is assumed to occur at the highest concentration measured by SWRI for each portion of the inventory. 


$$
\begin{array}{ll}
\mathrm{ppm}_{238 \mathrm{Max}}=\left(\begin{array}{l}
0.45 \\
1.01 \\
29.0 \\
0.94
\end{array}\right) \frac{\mathrm{mg}}{\mathrm{kg}} & \mathrm{M}_{\mathrm{ThN}}=\left(\begin{array}{l}
8.637 \times 10^{5} \\
1.507 \times 10^{6} \\
6.273 \times 10^{5} \\
2.186 \times 10^{5}
\end{array}\right) \mathrm{kg} \\
\mathrm{M}_{238}=\mathrm{M}_{\text {ThN }} \mathrm{ppm}_{238 \mathrm{Max}} & \mathrm{M}_{238}=20.307 \mathrm{~kg}
\end{array}
$$

The total ${ }^{238} \mathrm{U}$ activity is given by $A_{238}=S p A_{U 238} M_{238} . \quad \mathrm{A}_{238}=6.827 \times 10^{9} \mathrm{pCi}$

The ${ }^{222} \mathrm{Rn}$ activity may be obtained from readily available decay calculators.

For an initial ${ }^{238} \mathrm{U}$ activity of $1 \times 10^{6} \mathrm{~Bq}$, the following table displays the activities in the ${ }^{238} \mathrm{U}$ decay sequence at 1000 years:

\begin{tabular}{ll|l}
\hline Activities (in Bq) after 1000 years assuming & $\begin{array}{l}\text { Total activity (in Bq) after } 1000 \text { years assuming } \\
\text { an initial activity of } 1 \times 10^{6} \mathrm{~Bq}:\end{array}$ \\
an initial activity of $1 \times 10^{6} \mathrm{~Bq}:$ & \\
${ }^{238} \mathrm{U}$ & $1.000 \times 10^{6}$ & \\
${ }^{234} \mathrm{Th}$ & $1.000 \times 10^{6}$ & \\
${ }^{234 \mathrm{~m}} \mathrm{~Pa}$ & $1.000 \times 10^{6}$ & \\
${ }^{234} \mathrm{U}$ & $2.826 \times 10^{3}$ & \\
${ }^{230} \mathrm{Th}$ & 12.86 & \\
${ }^{226} \mathrm{Ra}$ & 1.651 & \\
${ }^{222} \mathrm{Rn}$ & 1.651 & \\
${ }^{218} \mathrm{Po}$ & 1.651 & \\
${ }^{214} \mathrm{~Pb}$ & 1.650 & \\
${ }^{214} \mathrm{Bi}$ & 1.650 & \\
${ }^{214} \mathrm{Po}$ & 1.650 & \\
${ }^{210} \mathrm{~Pb}$ & 1.505 & \\
${ }^{210} \mathrm{Bi}$ & 1.505 & \\
${ }^{210} \mathrm{Po}$ & 1.503 & \\
\hline
\end{tabular}

Source: Data obtained from the World Information Service on Energy, universal decay calculator, URL: http://www.antenna.nl/wise/uranium/rcc.html, accessed Dec. 6, 2002.

From the decay information presented above, the decay of ${ }^{238} \mathrm{U}$ in the thorium nitrate inventory would produce $\mathrm{a}^{222} \mathrm{Rn}$ activity at 1000 years that is $1.651 \times 10^{-6}$ the activity of the ${ }^{238} \mathrm{U}$.

$$
\mathrm{A}_{222 \text { fromU238 }}=1.651 \times 10^{-6} \mathrm{~A}_{238} \quad \mathrm{~A}_{222 \text { fromU238 }}=1.127 \times 10^{4} \mathrm{pCi}
$$




\section{CURRENT THORIUM-230 ACTIVITIES}

The ${ }^{230} \mathrm{Th}$ activities are computed for each distinct portion of the thorium nitrate inventory. The average ${ }^{230}$ Th activity per gram of thorium nitrate measured by SWRI is multiplied by the total mass of thorium nitrate for the relevant portion of the inventory.

$$
\begin{aligned}
& \mathrm{A}_{\mathrm{Th} 230 \mathrm{invHD}}=\max \left(\mathrm{A}_{\mathrm{Th} 230 \mathrm{HD}}\right) \\
& \mathrm{A}_{\mathrm{Th} 230 \mathrm{invHD}}=4.47 \times 10^{3} \frac{\mathrm{pCi}}{\mathrm{gm}} \\
& A_{\mathrm{Th}^{2} 30 \mathrm{in} 0}=A_{\mathrm{Th} 230 \mathbf{i n H D}} \mathrm{M}_{\mathrm{ThH}_{0}} \\
& A_{\text {Th230ino } 0}=3.861 \times 10^{12} \mathrm{pCi} \\
& \mathrm{A}_{\mathrm{Th230invCD}}=\max \left(\mathrm{A}_{\mathrm{Th} 230 \mathrm{CD}}\right) \\
& \mathrm{A}_{\mathrm{Th} 230 \mathrm{invCD}}=4.984 \times 10^{3} \frac{\mathrm{pCi}}{\mathrm{gm}} \\
& A_{\text {Th230in } 1}=A_{\text {Th230inCD }} M_{T h N 1} \\
& A_{\text {Tr230in 1 }}=7.513 \times 10^{12} \mathrm{pCi} \\
& \mathrm{A}_{\mathrm{Th230invCF}}=\max \left(\mathrm{A}_{\mathrm{Th} 230 \mathrm{CF}}\right) \\
& \mathrm{A}_{\mathrm{Th230invCF}}=4.995 \times 10^{4} \frac{\mathrm{pCi}}{\mathrm{gm}} \\
& \mathrm{A}_{\mathrm{Th} 230 \mathrm{ir} \mathrm{T}_{2}}=\mathrm{A}_{\mathrm{Th} 230 \mathrm{in} \sigma \mathrm{CF}} \mathrm{M}_{\mathrm{ThH}_{2}} \\
& \mathrm{~A}_{\text {Tr230in } 2}=3.133 \times 10^{13} \mathrm{pCi} \\
& \mathrm{A}_{\mathrm{Th} 230 \mathrm{invCl}}=\max \left(\mathrm{A}_{\mathrm{Th} 230 \mathrm{CI}}\right) \\
& \mathrm{A}_{\text {Th230invCI }}=7.632 \times 10^{3} \frac{\mathrm{pCi}}{\mathrm{gm}} \\
& A_{\text {Tr230inT } 3}=A_{\text {Th230in CI }} M_{\text {ThH } 3} \\
& \mathrm{~A}_{\text {Th230in } 3}=1.668 \times 10^{12} \mathrm{pCi}
\end{aligned}
$$

The ${ }^{230} \mathrm{Th}$ activities are computed for the Hammond Depot domestic inventory, Curtis Bay Depot domestic inventory, Curtis Bay Depot French inventory, and Curtis Bay Depot Indian inventory, respectively. These computations are based on measurements made by SWRI.

$$
A_{\mathrm{Tr} 20 \mathrm{ivt}}=\left(\begin{array}{l}
3.861 \times 10^{12} \\
7.513 \times 10^{12} \\
3.133 \times 10^{13} \\
1.668 \times 10^{12}
\end{array}\right) \mathrm{pCi}
$$




\section{THORIUM-230 AS A FUNCTION OF TIME}

The ${ }^{230}$ Th content of the inventory, which varies with time, is given by $A_{T h 230}(t, j)$, $j=0$. . .3), where the subscripts $j=0,1,2,3$ refer to Hammond Depot domestic, Curtis Bay Depot domestic, Curtis Bay Depot French, and Curtis Bay Depot Indian inventories, respectively,

$$
\begin{aligned}
& A_{\text {Th230 }}(t, j)=A_{\operatorname{Th} 230 \text { iro } j} e^{-\lambda \operatorname{Th} 230 t} \\
& t=\left(\begin{array}{l}
100 \\
1,000 \\
10,000 \\
100,000
\end{array}\right) y \quad i=0 . .3
\end{aligned}
$$

The change in ${ }^{230} \mathrm{Th}$ activity with time is giv en by $A_{\text {Th230 }}(t)$. The times are $100,1,000$, 10,000 , and 100,000 years after analysis by SWRI. The ${ }^{230} \mathrm{Th}$ generated by each component of the inventory is computed separately.

$$
\begin{aligned}
& A_{\mathbb{T} 230}\left(t_{i}, 0\right)=\left(\begin{array}{l}
3.857 \times 10^{12} \\
3.825 \times 10^{12} \\
3.522 \times 10^{12} \\
1.540 \times 10^{12}
\end{array}\right) \mathrm{pCi} \quad A_{\mathbb{T} 230}\left(t_{i}, 1\right)=\left(\begin{array}{l}
7.506 \times 10^{12} \\
7.444 \times 10^{12} \\
6.853 \times 10^{12} \\
2.996 \times 10^{12}
\end{array}\right) \mathrm{pCi} \\
& A_{\mathbb{T} 230}\left(t_{1}, 2\right)=\left(\begin{array}{l}
3.130 \times 10^{13} \\
3.104 \times 10^{13} \\
2.858 \times 10^{13} \\
1.250 \times 10^{13}
\end{array}\right) p C_{1}
\end{aligned}
$$

The ${ }^{230}$ Th contained in a gram of the th orium nitrate inventory is given by $A_{230 T h N}(t, j)$, where $(j=0,1,2,3)$ refers to Hammond Depot domestic, Curtis Bay Depot domestic, Curtis Bay Depot French, and Curtis Bay Depot Indian inventories, respectively,

$$
A_{230 \mathrm{ThN}}(t, j)=\frac{A_{\mathbb{T} 230}(t, j)}{M_{\mathbb{T W N} j}} .
$$


The times for evaluation of the ${ }^{230} \mathrm{Th}$ activity in the inventory are 100, 1,000, 10,000, and 100,000 years after analysis by SWRI.

$$
\begin{aligned}
& A_{230 \mathrm{TWH}}\left(\mathrm{t}_{\mathrm{i}}, 0\right)=\left(\begin{array}{l}
4.466 \times 10^{3} \\
4.429 \times 10^{3} \\
4.077 \times 10^{3} \\
1.783 \times 10^{3}
\end{array}\right) \quad \frac{\mathrm{pCi}}{\mathrm{gm}} \quad \mathrm{A}_{230 \mathrm{TWH}}\left(\mathrm{t}_{\mathrm{i}}, 1\right)=\left(\begin{array}{l}
4.979 \times 10^{3} \\
4.938 \times 10^{3} \\
4.546 \times 10^{3} \\
1.988 \times 10^{3}
\end{array}\right) \frac{\mathrm{pCi}}{\mathrm{gm}} \\
& \mathrm{A}_{230 \mathrm{TH}}\left(\mathrm{t}_{\mathrm{i}}, 2\right)=\left(\begin{array}{l}
4.99 \times 10^{4} \\
4.949 \times 10^{4} \\
4.556 \times 10^{4} \\
1.992 \times 10^{4}
\end{array}\right) \quad \frac{\mathrm{pCi}}{\mathrm{gm}} \quad \mathrm{A}_{230 \mathrm{Th}}\left(\mathrm{t}_{\mathrm{i}}, 3\right)=\left(\begin{array}{l}
7.625 \times 10^{3} \\
7.562 \times 10^{3} \\
6.962 \times 10^{3} \\
3.044 \times 10^{3}
\end{array}\right) \frac{\mathrm{pCi}}{\mathrm{gm}}
\end{aligned}
$$

\section{RADIUM-226 ACTIVITY AS A FUNCTION OF TIME}

The activity of ${ }^{226} \mathrm{Ra}$ as a function of time is given by $A_{\text {Raz26 }}(t, j)$. A Bateman equation for two isotopes is used to compute the activity of ${ }^{226} \mathrm{Ra}$ assuming an original quantity of ${ }^{230} \mathrm{Th}$ and specified decay times. The times are 100, 1,000,10,000, and 100,000 years after analysis by SWRI. The subscript $j(j=0,1,2,3)$ refers to Hammond Depot domestic, Curtis Bay Depot domestic, Curtis Bay Depot French, and Curtis Bay Depot Indian inventories, respectively.

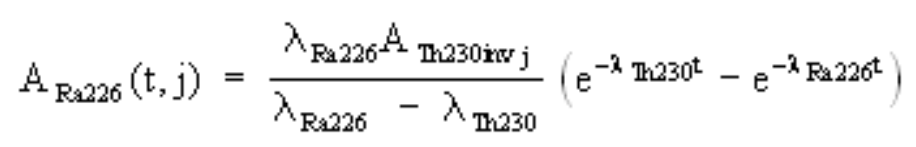

$$
\begin{aligned}
& \mathrm{A}_{\mathrm{Ra} 226}\left(\mathrm{t}_{\mathrm{i}}, 0\right)=\left(\begin{array}{l}
1.636 \times 10^{11} \\
1.351 \times 10^{12} \\
3.546 \times 10^{12} \\
1.573 \times 10^{12}
\end{array}\right) \mathrm{pCi} \quad \mathrm{A}_{\mathrm{Ra} 226}\left(\mathrm{t}_{\mathrm{i}}, 1\right)=\left(\begin{array}{l}
3.184 \times 10^{11} \\
2.628 \times 10^{12} \\
6.9 \times 10^{12} \\
3.061 \times 10^{12}
\end{array}\right) \mathrm{pCi}
\end{aligned}
$$




$$
\mathrm{A}_{\mathrm{R} a 226}\left(\mathrm{t}_{i}, 2\right)=\left(\begin{array}{l}
1.328 \times 10^{12} \\
1.096 \times 10^{13} \\
2.878 \times 10^{13} \\
1.277 \times 10^{13}
\end{array}\right) \mathrm{pCi} \quad \mathrm{A}_{\mathrm{Ra} 226}\left(\mathrm{t}_{\mathrm{i}}, 3\right)=\left(\begin{array}{l}
7.069 \times 10^{10} \\
5.836 \times 10^{11} \\
1.532 \times 10^{12} \\
6.796 \times 10^{11}
\end{array}\right) \mathrm{pCi}
$$

The ${ }^{226} \mathrm{Ra}$ contained in a gram of the thorium nitrate inventory is given by $A_{226 T h N}(t)$.

$$
A_{226 \mathbb{T H N}}(t, j)=\frac{A_{\mathrm{F}_{226} 6}(t, j)}{M_{\mathbb{T H} \mathrm{H}}}
$$

The variation of ${ }^{226} \mathrm{Ra}$ activity per gram is evaluated at $100,1,000,10,000$, and 100,000 years after analysis by SWRI.

$$
\begin{aligned}
& \mathrm{A}_{226 \mathrm{TWH}}\left(\mathrm{t}_{\mathrm{i}}, 0\right)=\left(\begin{array}{l}
1.894 \times 10^{2} \\
1.564 \times 10^{3} \\
4.106 \times 10^{3} \\
1.821 \times 10^{3}
\end{array}\right) \frac{\mathrm{pCi}}{\mathrm{gm}} \quad \mathrm{A}_{226 \mathrm{TW}}\left(\mathrm{t}_{\mathrm{i}}, 1\right)=\left(\begin{array}{l}
2.112 \times 10^{2} \\
1.744 \times 10^{3} \\
4.578 \times 10^{3} \\
2.031 \times 10^{3}
\end{array}\right) \frac{\mathrm{pCi}}{\mathrm{gm}} \\
& \mathrm{A}_{226 \mathrm{TWH}}\left(\mathrm{t}_{\mathrm{i}}, 2\right)=\left(\begin{array}{l}
2.117 \times 10^{3} \\
1.748 \times 10^{4} \\
4.588 \times 10^{4} \\
2.035 \times 10^{4}
\end{array}\right) \quad \frac{\mathrm{pCi}}{\mathrm{gm}} \quad \mathrm{A}_{226 \mathrm{MW}}\left(\mathrm{t}_{\mathrm{i}}, 3\right)=\left(\begin{array}{l}
3.234 \times 10^{2} \\
2.67 \times 10^{3} \\
7.01 \times 10^{3} \\
3.11 \times 10^{3}
\end{array}\right) \frac{\mathrm{pCi}}{\mathrm{gm}}
\end{aligned}
$$

\section{VARIATION OF RADON-222 ACTIVITY WITH TIME}

The activity of ${ }^{222} \mathrm{Rn}$ as a function of time is given by $A_{R n 222}(t)$. A Bateman equation for three isotopes is used to compute the activity of ${ }^{222} \mathrm{Rn}$ assuming an original quantity of ${ }^{230} \mathrm{Th}$ and specified decay times. The coefficients of the Bateman equation are $C_{1}, C_{2}$, and $C_{3}$.

$$
\begin{array}{ll}
\mathrm{C}_{1}=\left(\lambda_{\text {Ra226 }}-\lambda_{\text {Th230 }}\right)^{-1}\left(\lambda_{\text {Rn222 }}-\lambda_{\text {Th230 }}\right)^{-1} & \mathrm{C}_{1}=3.564 \times 10^{1} \mathrm{y}^{2} \\
\mathrm{C}_{2}=\left(\lambda_{\text {Th230 }}-\lambda_{\text {Ra226 }}\right)^{-1}\left(\lambda_{\text {Rn222 }}-\lambda_{\text {Ra226 }}\right)^{-1} & \mathrm{C}_{2}=-3.564 \times 10^{1} \mathrm{y}^{2}
\end{array}
$$




$$
\begin{aligned}
& \mathrm{C}_{3}=\left(\lambda_{\mathrm{Th} 230}-\lambda_{\mathrm{Rn} 222}\right)^{-1}\left(\lambda_{\mathrm{Ra} 226}-\lambda_{\mathrm{Rn} 222}\right)^{-1} \quad \mathrm{C}_{3}=2.284 \times 10^{-4} \mathrm{y}^{2} \\
& \mathrm{~A}_{\mathrm{Rr} 222}(\mathrm{t}, \mathrm{j})=\lambda_{\mathrm{R} 226} \lambda_{\mathrm{Rr} 222} \mathrm{~A}_{\mathrm{Th} 230 \mathrm{nin} \mathrm{j}}\left(\mathrm{C}_{1} \mathrm{e}^{-\lambda_{\mathrm{Th} 230 \mathrm{t}}}+\mathrm{C}_{2} \mathrm{e}^{-\lambda_{\mathrm{R} 226 \mathrm{t}}}+\mathrm{C}_{3} \mathrm{e}^{-\lambda_{\mathrm{Rr} 222 \mathrm{t}}}\right)
\end{aligned}
$$

For each portion of the thorium nitrate inventory (Hammond Depot domestic, Curtis Bay domestic, Curtis Bay French, and Curtis Bay Indian), the activities of ${ }^{222} \mathrm{Rn}$ are computed at 100 , $1,000,10,000$, and 100,000 years after analysis by SWRI.

$$
\begin{aligned}
& A_{\mathrm{Fr} 222}\left(t_{i}, 0\right)=\left(\begin{array}{l}
1.636 \times 10^{11} \\
1.351 \times 10^{12} \\
3.546 \times 10^{12} \\
1.573 \times 10^{12}
\end{array}\right) \mathrm{pCi} \quad \mathrm{A}_{\mathrm{Fr} 222}\left(\mathrm{t}_{\mathrm{i}}, 1\right)=\left(\begin{array}{l}
3.183 \times 10^{11} \\
2.628 \times 10^{12} \\
6.900 \times 10^{12} \\
3.061 \times 10^{12}
\end{array}\right) \mathrm{pCi} \\
& \mathrm{A}_{\mathrm{Fn} 222}\left(\mathrm{t}_{1}, 2\right)=\left(\begin{array}{c}
1.328 \times 10^{12} \\
1.096 \times 10^{13} \\
2.878 \times 10^{13} \\
1.277 \times 10^{13}
\end{array}\right) \mathrm{pCi} \quad \mathrm{A}_{\mathrm{Fn} 222}\left(\mathrm{t}_{\mathrm{i}}, 3\right)=\left(\begin{array}{c}
7.068 \times 10^{10} \\
5.836 \times 10^{11} \\
1.532 \times 10^{12} \\
6.796 \times 10^{11}
\end{array}\right) \mathrm{pCi}
\end{aligned}
$$

The variation with time of the ${ }^{222} \mathrm{Rn}$ activity per gram is given by

$$
A_{222 \mathrm{ThN}}(t, j)=\frac{A_{\mathrm{Rn} 222}(t, j)}{M_{\mathrm{ThN} j}}
$$

The times are 100,1,000,10,000, and 100,000 years after analysis by SWRI. The computations are performed for the following inventories, respectively, Hammond Depot domestic, Curtis Bay Depot domestic, Curtis Bay Depot French, and Curtis Bay Depot Indian.

$$
\mathrm{A}_{222 \mathrm{Th}}\left(\mathrm{t}_{\mathrm{i}}, 0\right)=\left(\begin{array}{l}
1.894 \times 10^{2} \\
1.564 \times 10^{3} \\
4.106 \times 10^{3} \\
1.821 \times 10^{3}
\end{array}\right) \quad \frac{\mathrm{pCi}}{\mathrm{gm}} \quad \mathrm{A}_{222 \mathrm{Thw}}\left(\mathrm{t}_{\mathrm{i}}, 1\right)=\left(\begin{array}{l}
2.112 \times 10^{2} \\
1.744 \times 10^{3} \\
4.578 \times 10^{3} \\
2.031 \times 10^{3}
\end{array}\right) \frac{\mathrm{pCi}}{\mathrm{gm}}
$$




$$
\mathrm{A}_{222 \mathrm{TW}}\left(\mathrm{t}_{\mathrm{i}}, 2\right)=\left(\begin{array}{l}
2.116 \times 10^{3} \\
1.747 \times 10^{4} \\
4.588 \times 10^{4} \\
2.035 \times 10^{4}
\end{array}\right) \quad \frac{\mathrm{pCi}}{\mathrm{gm}} \quad \mathrm{A}_{222 \mathrm{MWH}}\left(\mathrm{t}_{\mathrm{i}}, 3\right)=\left(\begin{array}{l}
3.234 \times 10^{2} \\
2.670 \times 10^{3} \\
7.010 \times 10^{3} \\
3.110 \times 10^{3}
\end{array}\right) \frac{\mathrm{pCi}}{\mathrm{gm}}
$$

The total ${ }^{222} \mathrm{Rn}$ activity at 1000 years is given by $A_{\text {222Total }}$.

$$
\mathrm{A}_{222 \mathrm{Tota}}=\sum_{\mathrm{j}} \mathrm{A}_{222 \mathrm{ThWH}}(1000 \mathrm{y}, \mathrm{j}) \quad \mathrm{A}_{222 \text { Total }}=2.345 \times 10^{4} \frac{\mathrm{pCi}}{\mathrm{gm}}
$$

The ${ }^{222} \mathrm{Rn}$ generated by decay of ${ }^{230} \mathrm{Th}$, which was processed into the thorium nitrate directly from the ore, is given by $A_{222 T h 230}$.

$$
A_{222 \text { from Th230 }}=A_{222 \text { Total } 1} \sum_{j} M_{\text {Thi } j} \quad A_{222 \text { from Th230 }}=7.544 \times 10^{13} \mathrm{pCi}
$$

The ratio of ${ }^{222} \mathrm{Rn}$ activity resulting from decay of ${ }^{230} \mathrm{Th}$ to ${ }^{222} \mathrm{Rn}$ activity resulting from decay of ${ }^{238} \mathrm{U}$ is given by $r_{230 t o 238}$.

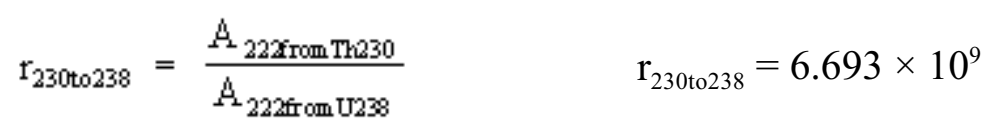

\section{THORIUM-232 ACTION LEVEL}

The ${ }^{232} \mathrm{Th}$ action level cited in Rev. 4 to the NTS Waste Acceptance Criteria (DOE 2002) is $8.1 \times 10^{8} \mathrm{~Bq} / \mathrm{m}^{3}$. The ${ }^{232} \mathrm{Th}$ activity concentration (activity per unit volume) in the thorium nitrate inventory is calculated from the maximum concentrations measured by SWRI.

$$
\begin{array}{ll}
\mathrm{ppm}_{232 \mathrm{Max}}=\left(\begin{array}{l}
401,000 \\
453,000 \\
453,000 \\
465,000
\end{array}\right) \frac{\mathrm{mg}}{\mathrm{kg}} & \mathrm{M}_{\mathrm{TWN}}=\left(\begin{array}{l}
8.637 \times 10^{5} \\
1.507 \times 10^{6} \\
6.273 \times 10^{5} \\
2.186 \times 10^{5}
\end{array}\right) \mathrm{kg} \\
\mathrm{M}_{232}=\mathrm{ppm}_{232 \mathrm{Max}} \mathrm{M}_{\mathrm{ThN}} & \mathrm{M}_{232}=1.415 \times 10^{6} \mathrm{~kg}
\end{array}
$$




$$
\begin{gathered}
\mathrm{C}_{232}=\frac{\mathrm{SpA}_{\mathrm{Th} 232} \mathrm{M}_{232}}{\mathrm{~V}_{0}} \quad \mathrm{C}_{232}=3.387 \times 10^{9} \frac{\mathrm{Bq}}{\mathrm{m}^{3}} \quad \mathrm{C}_{\mathrm{action}}=8.1 \times 10^{8} \frac{\mathrm{Bq}}{\mathrm{m}^{3}} \\
\mathrm{r}_{\text {CtoA }}=\frac{\mathrm{C}_{232}}{\mathrm{C}_{\mathrm{action}}} \\
\mathrm{r}_{\mathrm{CtoA}}=4.182
\end{gathered}
$$

\section{THORIUM-230 ACTION LEVEL}

The ${ }^{230} \mathrm{Th}$ action level cited in Rev. 4 to the NTS Waste Acceptance Criteria (DOE 2002) is $9.6 \times 10^{7} \mathrm{~Bq} / \mathrm{m}^{3}$. The concentration (activity per unit volume) of ${ }^{230} \mathrm{Th}$ in the thorium nitrate inventory varies with time,

$$
\mathrm{C}_{230}(\mathrm{t}, \mathrm{j})=\frac{A_{\mathrm{T} 230}(\mathrm{t}, \mathrm{j}) \rho_{\mathrm{TWW}}}{\mathrm{M}_{\mathrm{TLW} j}},
$$

where $(j=0,1,2,3)$ refers to Hammond Depot domestic inventory, Curtis Bay Depot domestic inventory, Curtis Bay Depot French inventory, and Curtis Bay Depot Indian inventory, respectively.

$$
\begin{aligned}
\mathrm{C}_{230}\left(\mathrm{t}_{\mathrm{i}}, 0\right) & =\left(\begin{array}{l}
3.123 \times 10^{8} \\
3.097 \times 10^{8} \\
2.851 \times 10^{8} \\
1.247 \times 10^{8}
\end{array}\right) \frac{\mathrm{Bq}}{\mathrm{m}^{3}} \quad \mathrm{C}_{230}\left(\mathrm{t}_{\mathrm{i}}, 1\right)=\left(\begin{array}{l}
3.482 \times 10^{8} \\
3.453 \times 10^{8} \\
3.179 \times 10^{8} \\
1.39 \times 10^{8}
\end{array}\right) \frac{\mathrm{Bq}}{\mathrm{m}^{3}} \\
\mathrm{C}_{230}\left(\mathrm{t}_{1}, 2\right) & =\left(\begin{array}{l}
3.49 \times 10^{9} \\
3.461 \times 10^{9} \\
3.186 \times 10^{9} \\
1.393 \times 10^{9}
\end{array}\right) \frac{\mathrm{Bq}}{\mathrm{m}^{3}} \quad \mathrm{C}_{230}\left(\mathrm{t}_{\mathrm{i}}, 3\right)=\left(\begin{array}{l}
5.332 \times 10^{8} \\
5.288 \times 10^{8} \\
4.868 \times 10^{8} \\
2.128 \times 10^{8}
\end{array}\right) \frac{\mathrm{Bq}}{\mathrm{m}^{3}} \\
\mathrm{C}_{\text {Antion } 230}=9.6 \times 10^{7} \frac{\mathrm{Bq}}{\mathrm{m}^{3}} &
\end{aligned}
$$


For $t=0$, the date of measurement,

$$
\begin{array}{ll}
\mathrm{A}_{0 \text { Th230 }}(\mathrm{t}, 0)=3.862 \times 10^{12} \mathrm{pCi} & \mathrm{A}_{0 \mathrm{Th} 230}(\mathrm{t}, 1)=7.515 \times 10^{12} \mathrm{pCi} \\
\mathrm{A}_{0 \text { Th230 }}(\mathrm{t}, 2)=3.134 \times 10^{13} \mathrm{pCi} & \mathrm{A}_{0 \mathrm{Th} 230}(\mathrm{t}, 3)=1.669 \times 10^{12} \mathrm{pCi}
\end{array}
$$

The total current ${ }^{230} \mathrm{Th}$ activity is given by $A_{\text {OTh230Total }}$.

$$
\mathrm{A}_{\text {0Th230Total }}=\sum_{\mathrm{j}} \mathrm{A}_{0 \mathrm{TL} 230}(\mathrm{t}, \mathrm{j}) \quad \mathrm{A}_{0 \mathrm{Th} 230 \mathrm{Total}}=4.439 \times 10^{13} \mathrm{pCi}
$$

The current activity concentration of ${ }^{230} \mathrm{Th}$ is giv en by $C_{\text {0Th230Total }}$.

$$
\mathrm{C}_{0 \mathrm{TL230 \textrm {Total }}}=\frac{\mathrm{A}_{0 \mathrm{~T} 230 \mathrm{Total}} \rho_{\mathrm{ThW}}}{\sum_{\mathrm{j}} \mathrm{M}_{\mathrm{ThN}}} \quad \mathrm{C}_{0 \mathrm{Th} 230 \mathrm{Total}}=9.65 \times 10^{8} \frac{\mathrm{Bq}}{\mathrm{m}^{3}}
$$

The current activity concentration of ${ }^{230} \mathrm{Th}$ in the thorium nitrate exceeds the ${ }^{230} \mathrm{Th}$ action limit by the factor $r_{230}$.

$$
\mathrm{r}_{230}=\frac{\mathrm{C}_{\text {0Th230Totol }}}{\mathrm{C}_{\text {Aution } 230}} \quad \mathrm{r}_{230}=10.1
$$

\section{RADIUM-226 ACTION LEVEL}

The ${ }^{226} \mathrm{Ra}$ action level cited in Rev. 4 to the NTS Waste Acceptance Criteria (DOE 2002) is $3.6 \times 10^{7} \mathrm{~Bq} / \mathrm{m}^{3}$.

$$
\mathrm{C}_{\text {Action } 226}=3.6 \times 10^{7} \frac{\mathrm{Bq}}{\mathrm{m}^{3}}
$$

The concentration of ${ }^{226} \mathrm{Ra}$ in the thorium nitrate inventory varies with time,

$$
\mathrm{C}_{\mathrm{R} 226}(\mathrm{t}, \mathrm{j})=\frac{A_{\mathrm{R} 226}(t, j) \rho_{\mathrm{ThN}}}{\mathrm{M}_{\mathrm{ThN} j}}
$$




$$
\begin{aligned}
& \mathrm{C}_{\mathrm{Ra} 236}\left(\mathrm{t}_{\mathrm{i}}, 0\right)=\left(\begin{array}{l}
1.325 \times 10^{7} \\
1.094 \times 10^{8} \\
2.871 \times 10^{8} \\
1.274 \times 10^{8}
\end{array}\right) \frac{\mathrm{Bq}}{\mathrm{m}^{3}} \quad \mathrm{C}_{\mathrm{Ra} 26}\left(\mathrm{t}_{\mathrm{i}}, 1\right)=\left(\begin{array}{l}
1.477 \times 10^{7} \\
1.219 \times 10^{8} \\
3.201 \times 10^{8} \\
1.42 \times 10^{8}
\end{array}\right) \frac{\mathrm{Bq}}{\mathrm{m}^{3}} \\
& \mathrm{C}_{\mathrm{Ra} 26}\left(\mathrm{t}_{\mathrm{i}}, 2\right)=\left(\begin{array}{l}
1.48 \times 10^{8} \\
1.222 \times 10^{9} \\
3.208 \times 10^{9} \\
1.423 \times 10^{9}
\end{array}\right) \quad \frac{\mathrm{Bq}}{\mathrm{m}^{3}} \quad \mathrm{C}_{\mathrm{Ra} 26}\left(\mathrm{t}_{\mathrm{i}}, 3\right)=\left(\begin{array}{l}
2.262 \times 10^{7} \\
1.867 \times 10^{8} \\
4.902 \times 10^{8} \\
2.175 \times 10^{8}
\end{array}\right) \frac{\mathrm{Bq}}{\mathrm{m}^{3}}
\end{aligned}
$$

The variation with time of the ratio of the ${ }^{226} \mathrm{Ra}$ concentration in the thorium nitrate inventory to the NTS action level is given by

$$
\mathrm{r}_{\mathrm{CR} 226}(\mathrm{t}, \mathrm{j})=\frac{\mathrm{C}_{\mathrm{Rn} 226}(\mathrm{t}, \mathrm{j})}{\mathrm{C}_{\mathrm{Action} 226}}
$$

The times are 100, 1,000, 10,000, and 100,000 years after measurement by SWRI.

$$
\begin{array}{ll}
\mathrm{r}_{\mathrm{CR} 226}\left(\mathrm{t}_{\mathrm{i}}, 0\right)=\left(\begin{array}{l}
0.368 \\
3.038 \\
7.976 \\
3.538
\end{array}\right) & \mathrm{r}_{\mathrm{CR} 226}\left(\mathrm{t}_{\mathrm{i}}, 1\right)=\left(\begin{array}{l}
0.41 \\
3.387 \\
8.893 \\
3.945
\end{array}\right) \\
\mathrm{r}_{\mathrm{CR} 226}\left(\mathrm{t}_{\mathrm{i}}, 2\right)=\left(\begin{array}{l}
4.112 \\
33.946 \\
89.122 \\
39.534
\end{array}\right) & \mathrm{r}_{\mathrm{CR} 226}\left(\mathrm{t}_{\mathrm{i}}, 3\right)=\left(\begin{array}{l}
0.628 \\
5.187 \\
13.617 \\
6.04
\end{array}\right) \\
\mathrm{r}_{\mathrm{CR} 226 \mathrm{total}}=\sum_{\mathrm{j}} \mathrm{r}_{\mathrm{CR} 226}(\mathrm{t}, \mathrm{j}) & \\
\mathrm{r}_{\mathrm{CR} 226 \mathrm{tot} \alpha 1}=\left(\begin{array}{l}
5.518 \\
45.557 \\
119.608 \\
53.057
\end{array}\right)
\end{array}
$$


The activity concentration of ${ }^{226} \mathrm{Ra}$ in the thorium nitrate will be slightly in excess of the NTS action level at 100 years. The activity of ${ }^{226} \mathrm{Ra}$ increases with time until roughly 10,000 years; hence, the current activity concentration of ${ }^{226} \mathrm{Ra}$ is near the NTS action level.

\section{CONCLUSIONS}

The constituents of the thorium nitrate are near or well above the applicable NTS action levels. The present activity concentration of ${ }^{232} \mathrm{Th}$ in the thorium nitrate inventory is about 4.2 times the NTS action level. The current activity concentration of ${ }^{230} \mathrm{Th}$ in the thorium nitrate inventory is about 10.1 times the NTS action level. The current activity concentration of ${ }^{226} \mathrm{Ra}$ is near the NTS action level.

The decay of ${ }^{238} \mathrm{U}$ is an insignificant source of ${ }^{222} \mathrm{Rn}$ in the thorium nitrate inventory. At 1000 years, over 6.6 billion times more ${ }^{222} \mathrm{Rn}$ results from the decay of ${ }^{230} \mathrm{Th}$ than from the decay of ${ }^{238} \mathrm{U}$.

\section{REFERENCE}

DOE (U.S. Department of Energy) 2002. Nevada Test Site Waste Acceptance Criteria, DOE/NV-325-Rev. 4, Nevada Operations Office, Waste Management Division, Feb. URL: http://www.nv.doe.gov/programs/envmgmt/RWAP/pdfs/DOENV325_REV4.pdf 


\section{Appendix F}

\section{RADON-222 EMISSION CALCULATIONS Using Preliminary Ore Data}

\section{INTRODUCTION}

The Nevada Test Site (NTS) is required to limit the emissions of radon from buried materials. Radon emissions from uranium and thorium decay sequences increase with time. The performance objective for NTS burial sites is $20 \mathrm{pCi} \cdot \mathrm{m}^{2} \cdot \mathrm{sec}^{-1}$ at 1000 years in the future.

The calculation of radon emissions has been performed for two cells at NTS: an upper cell, 26-ft depth, and a lower cell, 40-ft depth. The upper cell depth is typically used for burial of uranium and uranium-containing materials. The lower cell depth has been used for burial of thorium and thorium-containing materials. The data used for these calculations are derived from published estimates of the uranium content of thorium-containing ores.

This appendix presents the model used to perform the calculations, the computation of radon emissions from an upper cell, and the computation of radon emissions from a lower cell.

\section{BACKGROUND}

The February 1995 draft performance assessment (DOE 1995) provides the following information that may be used to determine the emission of ${ }^{222} \mathrm{Rn}$ from a burial cell. The parameters are specific to the geometry of Pit 6 (the one used for thorium from Fernald).

$$
\mathrm{J}=1 \times 10^{12}\left[\mathrm{~K}_{\text {up }} \mathrm{C}_{\mathrm{up}}(\mathrm{t})+\mathrm{K}_{\mathrm{low}} \mathrm{C}_{\text {low }}(\mathrm{t})\right]\left(\mathrm{pCi} \cdot \mathrm{m}^{-2} \cdot \mathrm{sec}^{-1}\right),
$$

where

$\mathrm{J}=$ surface ${ }^{222} \mathrm{Rn}$ flux from burial pit, $\mathrm{pCi} \cdot \mathrm{m}^{-2} \cdot \mathrm{sec}^{-1}$,

$\mathrm{K}_{\text {low }}=$ ratio of surface flux to ${ }^{226} \mathrm{Ra}$ activity concentration in the lower cell, $\mathrm{m} / \mathrm{sec}$,

$\mathrm{K}_{\text {up }}=$ ratio of surface flux to ${ }^{226} \mathrm{Ra}$ activity concentration in the upper cell, $\mathrm{m} / \mathrm{sec}$,

$\mathrm{C}_{\text {low }}=$ activity concentration for ${ }^{226} \mathrm{Ra}$ in the lower cell, $\mathrm{Ci} / \mathrm{m}^{3}$, and

$\mathrm{C}_{\text {up }}=$ activity concentration for ${ }^{226} \mathrm{Ra}$ in the upper cell, $\mathrm{Ci} / \mathrm{m}^{3}$.

$$
\mathrm{K}_{\mathrm{low}}=3.3 \times 10^{-11} \frac{\mathrm{m}}{\mathrm{sec}} \quad \mathrm{K}_{\text {up }}=5.3 \times 10^{-8} \frac{\mathrm{m}}{\mathrm{sec}}
$$




$$
\mathrm{Vol}_{\mathrm{Th}}=\left(\begin{array}{l}
1.437 \times 10^{3} \\
3.802 \times 10^{2} \\
1.325 \times 10^{2}
\end{array}\right) \mathrm{m}^{3} \quad \mathrm{t}=\left(\begin{array}{l}
100 \\
1,000 \\
10,000 \\
100,000
\end{array}\right) \mathrm{y} \quad \mathrm{i}=0 \ldots .3
$$

\section{EMISSIONS FROM THE UPPER CELL}

The first evaluation of emissions is done assuming that the thorium nitrate inventory is placed in the upper cell.

$$
C_{\Psi}(t, j)=\frac{A_{\mathrm{Ra} 226}(t, j)}{V_{O L} l_{T H}}
$$

The activity concentration equals the ${ }^{226}$ Ra activity divided by the volume of the thorium nitrate inventory produced from a specific ore: South African monazite, Malagasy Republic, or Indian.
$\mathrm{C}_{\text {low }}(\mathrm{t}, \mathrm{j})=0$
Calculations are performed below to determine the emissions from thorium nitrate buried in the lower cell.

$$
J(t)=\left(K_{\text {low }} \cdot C_{\text {low }}(t)+K_{\text {up }} \cdot C_{\text {up }}(t)\right)
$$

The conversion to picoCuries given in DOE (1995) has been ignored because the activity of ${ }^{226} \mathrm{Ra}$ is already computed in picoCuries.

The values of $C_{u p}(t)$ are computed at 100,1,000,10,000, and 100,000 years after separation from the ores: South African monazite, Malagasy Republic, and Indian. There is a peak in the ${ }^{226} \mathrm{Ra}$ concentration near 10,000 years.

$$
\begin{gathered}
\mathrm{C}_{\Psi}\left(\mathrm{t}_{\mathrm{i}}, 0\right)=\left(\begin{array}{l}
1.878 \times 10^{8} \\
1.55 \times 10^{9} \\
4.07 \times 10^{9} \\
1.805 \times 10^{9}
\end{array}\right) \frac{\mathrm{pCi}}{\mathrm{m}^{3}} \quad \mathrm{C}_{\Psi}\left(\mathrm{t}_{\mathrm{i}}, 1\right)=\left(\begin{array}{l}
4.326 \times 10^{8} \\
3.571 \times 10^{9} \\
9.376 \times 10^{9} \\
4.159 \times 10^{9}
\end{array}\right) \frac{\mathrm{pCi}}{\mathrm{m}^{3}} \\
\mathrm{C}_{\Psi}\left(\mathrm{t}_{\mathrm{i}}, 2\right)=\left(\begin{array}{l}
3.639 \times 10^{8} \\
3.004 \times 10^{9} \\
7.887 \times 10^{9} \\
3.499 \times 10^{9}
\end{array}\right) \frac{\mathrm{pCi}}{\mathrm{m}^{3}}
\end{gathered}
$$




$$
\mathrm{C}_{\text {lon }}\left(\mathrm{t}_{\mathrm{i}}, 0\right)=\left(\begin{array}{l}
0 \\
0 \\
0 \\
0
\end{array}\right) \quad \mathrm{C}_{\operatorname{lox}}\left(\mathrm{t}_{\mathrm{i}}, 1\right)=\left(\begin{array}{l}
0 \\
0 \\
0 \\
0
\end{array}\right) \quad \mathrm{C}_{\text {lon }}\left(\mathrm{t}_{\mathrm{i}}, 2\right)=\left(\begin{array}{l}
0 \\
0 \\
0 \\
0
\end{array}\right)
$$

The ${ }^{222} \mathrm{Rn}$ emissions from the ground above the disposal cell, $J(t, j)$, are computed at 100 , $1,000,10,000$, and 100,000 years after separation from each of the ores: South African monazite, Malagasy Republic, and Indian. The subscript $j(j=0,1,2)$ refers to the ores in the sequence given in the previous sentence.

The NTS performance objective for radon is an emission of less than $20 \mathrm{pCi} \cdot \mathrm{m}^{-2} \cdot \mathrm{sec}^{-1}$.

$$
\mathrm{J}_{\mathrm{obj}}<20 \frac{\mathrm{pCi}}{\mathrm{m}^{2} \cdot \mathrm{sec}}
$$

For the case of the upper cell only, $J(t, j)=K_{u p} \cdot C_{u p}(t, j)$.

$$
\begin{gathered}
\mathrm{J}\left(\mathrm{t}_{\mathrm{i}}, 0\right)=\left(\begin{array}{l}
9.952 \times 10^{0} \\
8.216 \times 10^{1} \\
2.157 \times 10^{2} \\
9.568 \times 10^{1}
\end{array}\right) \frac{\mathrm{pCi}}{\mathrm{m}^{2} \cdot \mathrm{sec}} \quad \mathrm{J}\left(\mathrm{t}_{\mathrm{i}}, 1\right)=\left(\begin{array}{l}
2.293 \times 10^{1} \\
1.893 \times 10^{2} \\
4.969 \times 10^{2} \\
2.204 \times 10^{2}
\end{array}\right) \frac{\mathrm{pCi}}{\mathrm{m}^{2} \cdot \mathrm{sec}} \\
\mathrm{J}\left(\mathrm{t}_{\mathrm{i}}, 2\right)=\left(\begin{array}{l}
1.929 \times 10^{1} \\
1.592 \times 10^{2} \\
4.18 \times 10^{2} \\
1.854 \times 10^{2}
\end{array}\right) \frac{\mathrm{pCi}}{\mathrm{m}^{2} \cdot \mathrm{sec}} \\
\mathrm{J}_{\text {total }}(\mathrm{t})=\sum_{\mathrm{j}} \mathrm{J}(\mathrm{t}, \mathrm{j}) \quad\left(\begin{array}{l}
52 \\
431 \\
1131 \\
502
\end{array}\right) \frac{\mathrm{pCi}}{\mathrm{m}^{2} \cdot \mathrm{sec}} \quad \mathrm{J}_{\text {totat1 }}(1000 \mathrm{y})=431 \frac{\mathrm{pCi}}{\mathrm{m}^{2} \cdot \mathrm{sec}}
\end{gathered}
$$

If the thorium nitrate inventory were buried in the upper cell, the ${ }^{222} \mathrm{Rn}$ emissions would exceed the performance objective for all times examined. 


\section{EMISSIONS FROM THE LOWER CELL}

The activity concentration equals the ${ }^{226} \mathrm{Ra}$ activity divided by the volume of the thorium nitrate inventory produced from a specific ore: South African monazite, Malagasy Republic, or Indian.

$$
\mathrm{C}_{\text {lon }}(\mathrm{t}, \mathrm{j})=\frac{\mathrm{A}_{\mathrm{R} 2226}(\mathrm{t}, \mathrm{j})}{V_{\mathrm{OWH}} \mathrm{j}} \quad \mathrm{C}_{\mathrm{up}}(\mathrm{t}, \mathrm{j})=0
$$

Calculations are performed in the previous section to determine the impact if thorium nitrate were stored in the upper cell.

The conversion to picoCuries given in DOE (1995) has been ignored because the activity of ${ }^{226} \mathrm{Ra}$ is already computed in picoCuries.

$$
\begin{gathered}
J(t)=\left(K_{\text {low }} \cdot C_{\text {low }}(t)+K_{\text {up }} \cdot C_{\text {up }}(t)\right) \\
C_{\Psi}\left(t_{i}, 0\right)=\left(\begin{array}{l}
0 \\
0 \\
0 \\
0
\end{array}\right) \quad C_{\Psi}\left(t_{i}, 1\right)=\left(\begin{array}{l}
0 \\
0 \\
0 \\
0
\end{array}\right) \quad C_{\Psi}\left(t_{i}, 2\right)=\left(\begin{array}{l}
0 \\
0 \\
0 \\
0
\end{array}\right)
\end{gathered}
$$

The values of $C_{u p}(t)$ are all zero because there is no upper disposal cell.

The values of $C_{\text {low }}(t)$ are computed at 100,1,000,10,000, and 100,000 years after separation from the ores: South African monazite, Malagasy Republic, and Indian. There is a peak in the ${ }^{226} \mathrm{Ra}$ concentration near 10,000 years.

$$
\begin{gathered}
\mathrm{C}_{\text {low }}\left(\mathrm{t}_{\mathrm{i}}, 0\right)=\left(\begin{array}{l}
1.878 \times 10^{8} \\
1.550 \times 10^{9} \\
4.070 \times 10^{9} \\
1.805 \times 10^{9}
\end{array}\right) \frac{\mathrm{pCi}}{\mathrm{m}^{3}} \quad \mathrm{C}_{\text {low }}\left(\mathrm{t}_{\mathrm{i}}, 1\right)=\left(\begin{array}{l}
4.326 \times 10^{8} \\
3.571 \times 10^{9} \\
9.376 \times 10^{9} \\
4.159 \times 10^{9}
\end{array}\right) \frac{\mathrm{pCi}}{\mathrm{m}^{3}} \\
\mathrm{C}_{\text {lon }}\left(\mathrm{t}_{\mathrm{i}}, 2\right)=\left(\begin{array}{l}
3.639 \times 10^{8} \\
3.004 \times 10^{9} \\
7.887 \times 10^{9} \\
3.499 \times 10^{9}
\end{array}\right) \frac{\mathrm{pCi}}{\mathrm{m}^{3}}
\end{gathered}
$$

For the case of a lower cell only, the upper cell term is dropped, giving $J(t, j)=K_{\text {low }} \cdot C_{\text {low }}(t, j)$. 
The ${ }^{222} \mathrm{Rn}$ emissions from the ground above the disposal cell, $J(t, j)$, are computed at 100 , $1,000,10,000$, and 100,000 years after separation from each of the ores: South African monazite, Malagasy Republic, and Indian. The subscript $j(j=0,1,2)$ refers to the ores in the sequence given in the previous sentence.

The NTS performance objective for radon is an emission of less than $20 \mathrm{pCi} \cdot \mathrm{m}^{-2} \cdot \mathrm{sec}^{-1}$.

$$
\mathrm{J}_{\text {obj }}<20 \frac{\mathrm{pCi}}{\mathrm{m}^{2} \cdot \mathrm{sec}}
$$

$$
\begin{aligned}
& \mathrm{J}\left(\mathrm{t}_{\mathrm{i}}, 0\right)=\left(\begin{array}{l}
0.0062 \\
0.0512 \\
0.1343 \\
0.0596
\end{array}\right) \frac{\mathrm{pCi}}{\mathrm{m}^{2} \cdot \mathrm{sec}} \mathrm{J}\left(\mathrm{t}_{\mathrm{i}}, 1\right)=\left(\begin{array}{l}
0.0143 \\
0.1179 \\
0.3094 \\
0.1373
\end{array}\right) \frac{\mathrm{pCi}}{\mathrm{m}^{2} \cdot \mathrm{sec}} \mathrm{J}\left(\mathrm{t}_{\mathrm{i}}, 2\right)=\left(\begin{array}{l}
0.012 \\
0.0991 \\
0.2603 \\
0.1155
\end{array}\right) \frac{\mathrm{pCi}}{\mathrm{m}^{2} \cdot \mathrm{sec}} \\
& \mathrm{J}_{\text {total }}(\mathrm{t})=\sum_{\mathrm{j}} \mathrm{J}(\mathrm{t}, \mathrm{j}) \quad \mathrm{J}_{\text {total }}(\mathrm{t})=\left(\begin{array}{l}
0.032 \\
0.268 \\
0.704 \\
0.312
\end{array}\right) \frac{\mathrm{pCi}}{\mathrm{m}^{2} \cdot \sec } \quad \mathrm{J}_{\text {total }}(1,000 \mathrm{y})=0.268 \frac{\mathrm{pCi}}{\mathrm{m}^{2} \cdot \sec }
\end{aligned}
$$

The ratio of the calculated ${ }^{222} \mathrm{Rn}$ emissions from the 40 -ft-deep trench to the performance objective is given by $r_{\text {calc2PO }}$. The ratios are calculated at 100,1,000,10,000, and 100,000 years after analysis of the thorium nitrate by Southwest Research Institute.

$$
\mathrm{r}_{\mathrm{cak} 2 \mathrm{PO}_{0}}(\mathrm{t})=\frac{\mathrm{J}_{\text {total }}(\mathrm{t})}{\mathrm{J}_{\text {obj }}} \quad \mathrm{r}_{\mathrm{calc} 2 \mathrm{PO} O}(\mathrm{t})=\left(\begin{array}{l}
0.16 \\
1.34 \\
3.52 \\
1.56
\end{array}\right) \% \quad \mathrm{r}_{\text {calc2 obj }}(1000 \mathrm{y})=1.34 \%
$$

The total computed ${ }^{222} \mathrm{Rn}$ emissions from the thorium nitrate inventory, when buried in a 40-ft-deep trench, would be well below the NTS performance objective, $20 \mathrm{pCi} \cdot \mathrm{m}^{-2} \cdot \mathrm{sec}^{-1}$, for all times considered. 


\section{CONCLUSIONS}

The thorium nitrate inventory must be buried below the standard 26- $\mathrm{ft}$ depth for uranium. If the thorium nitrate were buried at the 40-ft depth used for the Fernald thorium, the modeled radon emissions from the thorium nitrate would be substantially below the NTS performance objective.

\section{REFERENCE}

DOE (U.S. Department of Energy) 1995. Performance Assessment for the Area 5 Radioactive Waste Management Site at the Nevada Test Site, Draft, PE-NTS-18, prepared by Reynolds Electrical and Engineering Co., Inc., Las Vegas, Nev., for the Waste Management Division, DOE Nevada Operations Office. 


\section{Appendix G}

\section{RADON-222 EMISSION CALCULATIONS Using MaXimum Values}

\section{INTRODUCTION}

The Nevada Test Site (NTS) is required to limit the emissions of radon from buried materials. Radon emissions from uranium and thorium decay sequences increase with time. The performance objective for NTS burial sites is $20 \mathrm{pCi} \cdot \mathrm{m}^{-2} \cdot \mathrm{sec}^{-1}$ at 1000 years in the future.

The calculation of radon emissions has been performed for two cells at NTS: an upper cell, 26-ft depth, and a lower cell, 40-ft depth. The upper cell depth is typically used for burial of uranium and uranium-containing materials. The lower cell depth has been used for burial of thorium and thorium-containing materials. The data used for these calculations are derived from measurements made by the Southwest Research Institute (SWRI) on samples from the thorium nitrate stockpile.

This appendix presents the model used to perform the calculations, the computation of radon emissions from an upper cell, and the computation of radon emissions from a lower cell.

\section{BACKGROUND}

The February 1995 draft performance assessment (DOE 1995) provides the following information that may be used to determine the emission of ${ }^{222} \mathrm{Rn}$ from a burial cell. The parameters are specific to the geometry of Pit 6 (the one used for thorium from Fernald).

$$
\mathrm{J}=1 \times 10^{12}\left[\mathrm{~K}_{\text {up }} \mathrm{C}_{\text {up }}(\mathrm{t})+\mathrm{K}_{\text {low }} \mathrm{C}_{\text {low }}(\mathrm{t})\right]\left(\mathrm{pCi} \cdot \mathrm{m}^{-2} \cdot \mathrm{sec}^{-1}\right),
$$

where

$\mathrm{J}=$ surface $^{222} \mathrm{Rn}$ flux from burial pit, $\mathrm{pCi} \cdot \mathrm{m}^{-2} \cdot \mathrm{sec}^{-1}$,

$\mathrm{K}_{\text {low }}=$ ratio of surface flux to ${ }^{226} \mathrm{Ra}$ activity concentration in the lower cell, $\mathrm{m} / \mathrm{sec}$,

$\mathrm{K}_{\mathrm{up}}=$ ratio of surface flux to ${ }^{226} \mathrm{Ra}$ activity concentration in the upper cell, $\mathrm{m} / \mathrm{sec}$,

$\mathrm{C}_{\text {low }}=$ activity concentration for ${ }^{226} \mathrm{Ra}$ in the lower cell, $\mathrm{Ci} / \mathrm{m}^{3}$, and

$\mathrm{C}_{\mathrm{up}}=$ activity concentration for ${ }^{226} \mathrm{Ra}$ in the upper cell, $\mathrm{Ci} / \mathrm{m}^{3}$.

$$
\mathrm{K}_{\text {low }}=3.3 \times 10^{-11} \frac{\mathrm{m}}{\mathrm{sec}} \quad \mathrm{K}_{\text {up }}=5.3 \times 10^{-8} \frac{\mathrm{m}}{\mathrm{sec}}
$$




$$
\mathrm{Vol}_{\mathrm{ThW}}=\left(\begin{array}{l}
4.57 \times 10^{2} \\
7.975 \times 10^{2} \\
3.319 \times 10^{2} \\
1.156 \times 10^{2}
\end{array}\right) \mathrm{m}^{3} \quad \mathrm{t}=\left(\begin{array}{l}
100 \\
1,000 \\
10,000 \\
100,000
\end{array}\right) \mathrm{y}
$$

\section{EMISSIONS FROM THE UPPER CELL}

The first evaluation of emissions is done assuming that the thorium nitrate inventory is placed in the upper cell.

$$
C_{\Psi}(t, j)=\frac{A_{R_{2226}}(t, j)}{V_{01} l_{\mathbb{W} j}} \quad \begin{aligned}
& \text { The activity concentration equals the }{ }^{226} \mathrm{Ra} \text { activity divided by } \\
& \text { the volume of a specific portion of the thorium nitrate: } \\
& \text { Hammond Depot domestic, Curtis Bay Depot domestic, Curtis } \\
& \text { Bay Depot French, and Curtis Bay Depot Indian inventories. }
\end{aligned}
$$
$\mathrm{C}_{\text {low }}(\mathrm{t}, \mathrm{j})=0 \quad$ Calculations are performed below to determine the emissions from thorium nitrate buried in the lower cell.

$$
J(t)=\left(K_{\text {low }} \cdot C_{\text {low }}(t)+K_{\text {up }} \cdot C_{\text {up }}(t)\right)
$$

The conversion to picoCuries given in DOE (1995) has been ignored because the activity of ${ }^{226} \mathrm{Ra}$ is already computed in picoCuries.

The values of $C_{u p}(t)$ are computed at 100,1,000,10,000, and 100,000 years after analysis by SWRI from the Hammond Depot domestic, Curtis Bay Depot domestic, Curtis Bay Depot French, and Curtis Bay Depot Indian inventories.

$$
\mathrm{C}_{\Psi}\left(\mathrm{t}_{\mathrm{i}}, 0\right)=\left(\begin{array}{l}
3.58 \times 10^{8} \\
2.956 \times 10^{9} \\
7.76 \times 10^{9} \\
3.442 \times 10^{9}
\end{array}\right) \frac{\mathrm{pCi}}{\mathrm{m}^{3}} \quad \mathrm{C}_{\mathbf{\Psi}}\left(\mathrm{t}_{\mathrm{i}}, 1\right)=\left(\begin{array}{l}
3.992 \times 10^{8} \\
3.296 \times 10^{9} \\
8.652 \times 10^{9} \\
3.838 \times 10^{9}
\end{array}\right) \frac{\mathrm{pCi}}{\mathrm{m}^{3}}
$$




$$
\begin{aligned}
& \mathrm{C}_{\Psi}\left(\mathrm{t}_{\mathrm{i}}, 2\right)=\left(\begin{array}{l}
4.001 \times 10^{9} \\
3.303 \times 10^{10} \\
8.671 \times 10^{10} \\
3.847 \times 10^{10}
\end{array}\right) \frac{\mathrm{pCi}}{\mathrm{m}^{3}} \quad \mathrm{C}_{\Psi}\left(\mathrm{t}_{\mathrm{i}}, 3\right)=\left(\begin{array}{c}
6.113 \times 10^{8} \\
5.046 \times 10^{9} \\
1.325 \times 10^{10} \\
5.877 \times 10^{9}
\end{array}\right) \frac{\mathrm{pCi}}{\mathrm{m}^{3}} \\
& \mathrm{C}_{\text {lon }}\left(\mathrm{t}_{\mathrm{i}}, 0\right)=\left(\begin{array}{l}
0 \\
0 \\
0 \\
0
\end{array}\right) \quad \mathrm{C}_{\mathrm{loN}}\left(\mathrm{t}_{\mathrm{i}}, 1\right)=\left(\begin{array}{l}
0 \\
0 \\
0 \\
0
\end{array}\right) \quad \mathrm{C}_{\mathrm{loN}}\left(\mathrm{t}_{\mathrm{i}}, 2\right)=\left(\begin{array}{l}
0 \\
0 \\
0 \\
0
\end{array}\right) \quad \mathrm{C}_{\text {lon }}\left(\mathrm{t}_{\mathrm{i}}, 3\right)=\left(\begin{array}{l}
0 \\
0 \\
0 \\
0
\end{array}\right)
\end{aligned}
$$

The ${ }^{222} \mathrm{Rn}$ emissions from the ground above the disposal cell, $J(t, j)$, are computed at 100 , 1,000, 10,000, and 100,000 years after analysis by SWRI from the Hammond Depot domestic, Curtis Bay Depot domestic, Curtis Bay Depot French, and Curtis Bay Depot Indian inventories. The subscript $j(j=0,1,2,3)$ refers to the analyzed materials in the sequence given in the previous sentence.

The NTS performance objective for radon is an emission of less than $20 \mathrm{pCi} \cdot \mathrm{m}^{-2} \cdot \mathrm{sec}^{-1}$.

$$
\mathrm{J}_{\text {obj }}<20 \frac{\mathrm{pCi}}{\mathrm{m}^{2} \cdot \mathrm{sec}}
$$

For the case of the upper cell only, $J(t, j)=K_{u p} \cdot C_{u p}(t, j)$.

$$
\begin{aligned}
& \mathrm{J}\left(\mathrm{t}_{\mathrm{i}}, 0\right)=\left(\begin{array}{l}
1.897 \times 10^{1} \\
1.567 \times 10^{2} \\
4.113 \times 10^{2} \\
1.824 \times 10^{2}
\end{array}\right) \frac{\mathrm{pCi}}{\mathrm{m}^{2} \cdot \mathrm{sec}} \quad \mathrm{J}\left(\mathrm{t}_{\mathrm{i}}, 1\right)=\left(\begin{array}{l}
2.116 \times 10^{1} \\
1.747 \times 10^{2} \\
4.586 \times 10^{2} \\
2.034 \times 10^{2}
\end{array}\right) \frac{\mathrm{pCi}}{\mathrm{m}^{2} \cdot \mathrm{sec}} \\
& \mathrm{J}\left(\mathrm{t}_{\mathrm{i}}, 2\right)=\left(\begin{array}{l}
2.12 \times 10^{2} \\
1.75 \times 10^{3} \\
4.596 \times 10^{3} \\
2.039 \times 10^{3}
\end{array}\right) \frac{\mathrm{pCi}}{\mathrm{m}^{2} \cdot \mathrm{sec}} \\
& \mathrm{J}\left(\mathrm{t}_{\mathrm{i}}, 3\right)=\left(\begin{array}{l}
3.24 \times 10^{1} \\
2.675 \times 10^{2} \\
7.022 \times 10^{2} \\
3.115 \times 10^{2}
\end{array}\right) \frac{\mathrm{pCi}}{\mathrm{m}^{2} \cdot \mathrm{sec}}
\end{aligned}
$$




$$
\mathrm{J}_{\text {total }}(\mathrm{t})=\sum_{\mathrm{j}} \mathrm{J}(\mathrm{t}, \mathrm{j}) \quad \mathrm{J}_{\text {total }}(\mathrm{t})=\left(\begin{array}{c}
285 \\
2349 \\
6168 \\
2736
\end{array}\right) \frac{\mathrm{pCi}}{\mathrm{m}^{2} \cdot \sec } \quad \mathrm{J}_{\text {total }}(1000 \mathrm{y})=2349 \frac{\mathrm{pCi}}{\mathrm{m}^{2} \cdot \sec }
$$

The ratio of the calculated ${ }^{222} \mathrm{Rn}$ emissions from the 40 -ft-deep trench to the performance objective is given by $r_{\text {calc2PO }}$. The ratios are calculated at 100,1,000, 10,000, and 100,000 years after analys is of the thorium nitrate by SWRI.

$$
r_{\text {car } 2 \mathrm{PO}}(t)=\frac{J_{\text {total }}(t)}{J_{\text {obj }}} \quad r_{\text {car } 2 \mathrm{PO}}(t)=\left(\begin{array}{c}
1,423 \\
11,746 \\
30,839 \\
13,680
\end{array}\right) \% \quad r_{\text {calc2PO }}(1000 y)=11,746 \%
$$

If the thorium nitrate inventory were buried in the upper cell, the ${ }^{222} \mathrm{Rn}$ emissions would exceed the performance objective for all times examined.

\section{EMISSIONS FROM THE LOWER CELL}

The second evaluation of emissions is done assuming that the thorium nitrate inventory is placed in the lower cell.

$$
C_{\text {lon }}(t, j)=\frac{A_{\mathrm{RA}_{226}}(t, j)}{V_{\mathrm{ol}} \mathrm{ThN}_{\mathrm{T}}}
$$

The activity concentration equals the ${ }^{226} \mathrm{Ra}$ activity divided by the volume of a specific portion of the thorium nitrate: Hammond Depot domestic, Curtis Bay Depot domestic, Curtis Bay Depot French, and Curtis Bay Depot Indian inventories.

$\mathrm{C}_{\mathrm{up}}(\mathrm{t}, \mathrm{j})=0 \quad$ It is assumed that there is no material in the upper cell.

$$
J(t)=\left(K_{\text {low }} \cdot C_{\text {low }}(t)+K_{\text {up }} \cdot C_{\text {up }}(t)\right)
$$

The conversion to picoCuries given in DOE (1995) has been ignored because the activity of ${ }^{226} \mathrm{Ra}$ is already computed in picoCuries. 


$$
\mathrm{C}_{\Psi}\left(\mathrm{t}_{i}, 0\right)=\left(\begin{array}{l}
0 \\
0 \\
0 \\
0
\end{array}\right) \quad \mathrm{C}_{\Psi}\left(\mathrm{t}_{\mathrm{i}}, 1\right)=\left(\begin{array}{l}
0 \\
0 \\
0 \\
0
\end{array}\right) \quad \mathrm{C}_{\Psi}\left(\mathrm{t}_{\mathrm{i}}, 2\right)=\left(\begin{array}{l}
0 \\
0 \\
0 \\
0
\end{array}\right) \quad \mathrm{C}_{\Psi_{\Psi}}\left(\mathrm{t}_{\mathrm{i}}, 3\right)=\left(\begin{array}{l}
0 \\
0 \\
0 \\
0
\end{array}\right)
$$

The values of $C_{u p}(t)$ are all zero because there is nothing in the upper disposal cell.

The values of $C_{\text {low }}(t)$ are computed at 100,1,000,10,000, and 100,000 years after analysis by SWRI from the Hammond Depot domestic, Curtis Bay Depot domestic, Curtis Bay Depot French, and Curtis Bay Depot Indian inventories. There is a peak in the ${ }^{226} \mathrm{Ra}$ concentration near 10,000 years.

$$
\begin{aligned}
& \mathrm{C}_{\text {lon }}\left(\mathrm{t}_{\mathrm{i}}, 0\right)=\left(\begin{array}{l}
3.580 \times 10^{8} \\
2.956 \times 10^{9} \\
7.760 \times 10^{9} \\
3.442 \times 10^{9}
\end{array}\right) \frac{\mathrm{pCi}}{\mathrm{m}^{3}} \quad \mathrm{C}_{\text {lon }}\left(\mathrm{t}_{\mathrm{i}}, 1\right)=\left(\begin{array}{l}
3.992 \times 10^{8} \\
3.296 \times 10^{9} \\
8.652 \times 10^{9} \\
3.838 \times 10^{9}
\end{array}\right) \frac{\mathrm{pCi}}{\mathrm{m}^{3}} \\
& \mathrm{C}_{\text {lon }}\left(\mathrm{t}_{\mathrm{i}}, 2\right)=\left(\begin{array}{l}
4.001 \times 10^{9} \\
3.303 \times 10^{10} \\
8.671 \times 10^{10} \\
3.847 \times 10^{10}
\end{array}\right) \frac{\mathrm{pCi}}{\mathrm{m}^{3}} \quad \mathrm{C}_{\text {lon }}\left(\mathrm{t}_{\mathrm{i}}, 3\right)=\left(\begin{array}{l}
6.113 \times 10^{8} \\
5.046 \times 10^{9} \\
1.325 \times 10^{10} \\
5.877 \times 10^{9}
\end{array}\right) \frac{\mathrm{pCi}}{\mathrm{m}^{3}}
\end{aligned}
$$

For the case of material in the lower cell only, $J(t, j)=K_{\text {low }} \cdot C_{\text {low }}(t, j)$.

The ${ }^{222} \mathrm{Rn}$ emissions from the ground above the disposal cell, $J(t, j)$, are computed at 100 , 1,000, 10,000, and 100,000 years analysis by SWRI from the Hammond Depot domestic, Curtis Bay Depot domestic, Curtis Bay Depot French, and Curtis Bay Depot Indian inventories. The subscript $j(j=0,1,2,3)$ refers to the analyzed materials in the sequence given in the previous sentence.

The NTS performance objective for ${ }^{222} \mathrm{Rn}$ is an emission of less than $20 \mathrm{pCi} \cdot \mathrm{m}^{-2} \cdot \mathrm{sec}^{-1}$.

$$
\mathrm{J}_{\text {obj }}<20 \frac{\mathrm{pCi}}{\mathrm{m}^{2} \cdot \mathrm{sec}}
$$




$$
\begin{gathered}
\mathrm{J}\left(\mathrm{t}_{\mathrm{i}}, 0\right)=\left(\begin{array}{l}
0.0118 \\
0.0975 \\
0.2561 \\
0.1136
\end{array}\right) \frac{\mathrm{pCi}}{\mathrm{m}^{2} \cdot \mathrm{sec}} \mathrm{J}\left(\mathrm{t}_{\mathrm{i}}, 1\right)=\left(\begin{array}{l}
0.0132 \\
0.1088 \\
0.2855 \\
0.1267
\end{array}\right) \frac{\mathrm{pCi}}{\mathrm{m}^{2} \cdot \sec } \\
\mathrm{J}\left(\mathrm{t}_{\mathrm{i}}, 2\right)=\left(\begin{array}{l}
0.132 \\
1.0899 \\
2.8615 \\
1.2694
\end{array}\right) \frac{\mathrm{pCi}}{\mathrm{m}^{2} \cdot \mathrm{sec}} \quad \mathrm{J}\left(\mathrm{t}_{\mathrm{i}}, 3\right)=\left(\begin{array}{l}
0.020 \\
0.167 \\
0.437 \\
0.194
\end{array}\right) \frac{\mathrm{pCi}}{\mathrm{m}^{2} \cdot \mathrm{sec}} \\
\mathrm{J}_{\text {total } 1}(t)=\sum_{\mathrm{j}} \mathrm{J}(\mathrm{t}, \mathrm{j}) \quad \mathrm{J}_{\text {total }}(\mathrm{t})=\left(\begin{array}{l}
0.177 \\
1.463 \\
3.840 \\
1.704
\end{array}\right) \frac{\mathrm{pCi}}{\mathrm{m}^{2} \cdot \sec } \quad \mathrm{J}_{\text {total }}(1,000 \mathrm{y})=1.463 \frac{\mathrm{pCi}}{\mathrm{m}^{2} \cdot \mathrm{sec}}
\end{gathered}
$$

The ratio of the calculated ${ }^{222} \mathrm{Rn}$ emissions from the 40 -ft-deep trench to the performance objective is given by $r_{\text {calc } 2 P O}$. The ratios are calculated at $100,1,000,10,000$, and 100,000 years after analysis of the thorium nitrate by SWRI.

$$
\mathrm{r}_{\mathrm{cak} 2 \mathrm{PO}}(\mathrm{t})=\frac{\mathrm{J}_{\mathrm{total}}(\mathrm{t})}{\mathrm{J}_{\mathrm{obj}}} \quad \mathrm{r}_{\mathrm{cak2} 2 \mathrm{PO}}(\mathrm{t})=\left(\begin{array}{l}
0.9 \\
7.3 \\
19.2 \\
8.5
\end{array}\right) \% \quad \mathrm{r}_{\text {calc2PO }}(1000 \mathrm{y})=7.3 \%
$$

The total computed ${ }^{222} \mathrm{Rn}$ emissions from the thorium nitrate inventory, when buried in a 40-ft-deep trench, would be well below the NTS performance objective, $20 \mathrm{pCi} \cdot \mathrm{m}^{-2} \cdot \mathrm{sec}^{-1}$, at the surface of the ground, for all times considered. These computations were performed using the maximum ${ }^{230} \mathrm{Th}$ values reported by SWRI.

\section{CONCLUSIONS}

The thorium nitrate inventory must be buried below the $26-\mathrm{ft}$ depth that is standard for uranium. If the thorium nitrate were buried at the 40 - $\mathrm{ft}$ depth used for the Femald thorium, the modeled radon emissions from the thorium nitrate would be substantially below the NTS performance objective. 


\section{REFERENCE}

DOE (U.S. Department of Energy) 1995. Performance Assessment for the Area 5 Radioactive Waste Management Site at the Nevada Test Site, Draft, PE-NTS-18, prepared by Reynolds Electrical and Engineering Co., Inc., Las Vegas, Nev., for the Waste Management Division, DOE Nevada Operations Office. 


\section{THIS PAGE INTENTIONALLY LEFT BLANK.}


ORNL/TM-2003/52

\section{Internal Distribution}

1. M. E. Baldwin [1 CD]

2. D. W. Bradford [1 CD]

3. R. M. Canon [1 CD]

4. D. W. DePaoli [1 CD]

5. L. D. Duncan [1 CD]

6. T. O. Early [1 CD]

7. M. B. Hawk [1 hard copy, 1 CD]

8. W. C. Hayes [1 CD]

9-10. W. H. Hermes [2 hard copies, 2 CDs]

11. D. J. Hill [1 CD]

12. C. Y. Horton $[1 \mathrm{CD}]$

13. J. B. Hunt [1 CD]

14. T. D. Hylton [1 hard copy, $1 \mathrm{CD}$ ]

15. T. R. Jones [1 CD]

16. D. W. Lee [1 hard copy, $1 \mathrm{CD}]$

17. S. B. Ludwig [1 CD]

18. S. C. Marschman [1 CD]
19. C. H. Mattus [1 hard copy, 1 CD]

20. Brad Patton [1 CD]

21. N. E. Porter [1 CD]

22. B. A. Powers $[1 \mathrm{CD}]$

23. C. A. Schrof [1 CD]

24. J. H. Shelton [1 hard copy, $1 \mathrm{CD}$ ]

25. P. T. Singley [1 hard copy, $1 \mathrm{CD}$ ]

26. S. N. Storch [1 CD]

27. C. M. Sullivan [1 CD]

28. J. W. Terry [1 hard copy, $1 \mathrm{CD}]$

29. D. L. Williams, Jr. [1 CD]

30. D. R. Wolber [1 CD]

31. G. P. Zimmerman [1 CD]

32. Thorium nitrate library [1 hard copy, $1 \mathrm{CD}]$

33. Central Research Library [1 CD]

34. Laboratory Records-RC [1 hard copy, $1 \mathrm{CD}]$ 35-36. OSTI [2 CDs]

\section{External Distribution}

Jhon Carilli, U.S. National Nuclear Sec urity Administration, Nevada Operations Office, 232 Energy Way, North Las Vegas, NV 89030 [1 CD]

David Cunningham, U.S. Department of Energy, Oak Ridge Operations Office, Bldg. 4500-N, Oak Ridge National Laboratory, MS-6269, Oak Ridge, TN 37831 [1 CD]

Susan Krenzien, Hazmed, Inc., 232 Energy Way, MS-505, North Las Vegas, NV 89030 [1 hard copy, $1 \mathrm{CD}]$

Mike Pecullan, Defense Logistics Agency, Defense National Stockpile Center, 8725 John J.

Kingman Road, Fort Belvoir, VA 22060 [1 hard copy, 1 CD]

Gary Pyles, U.S. National Nucle ar Security Administration, Nevada Operations Office, 232 Energy

Way, North Las Vegas, NV 89030 [1 hard copy, 1 CD]

James Reafsnyder, U.S. Department of Energy, Oak Ridge Operations Office, P.O. Box 2001, MS-M6, Federal Building, Oak Ridge, TN 37831 [1 CD]

Kevin Reilly, Defense Logistics Agency, Defense National Stockpile Center, 8725 John J. Kingman Road, Fort Belvoir, VA 22060 [4 hard copies, 10 CDs]

Scott Romans, Defense Logistics Agency, Defense National Stockpile Center, 8725 John J. Kingman Road, Fort Belvoir, VA 22060 [1 hard copy, 1 CD] 
[This page intentionally left blank.] 